2014-08-01

\title{
Sediment Transport Conditions Near Culverts
}

Kyle Jay Rowley

Brigham Young University - Provo

Follow this and additional works at: https://scholarsarchive.byu.edu/etd

Part of the Civil and Environmental Engineering Commons

\section{BYU ScholarsArchive Citation}

Rowley, Kyle Jay, "Sediment Transport Conditions Near Culverts" (2014). Theses and Dissertations. 4252. https://scholarsarchive.byu.edu/etd/4252

This Thesis is brought to you for free and open access by BYU ScholarsArchive. It has been accepted for inclusion in Theses and Dissertations by an authorized administrator of BYU ScholarsArchive. For more information, please contact scholarsarchive@byu.edu, ellen_amatangelo@byu.edu. 


\section{Sediment Transport Conditions Near Culverts}

Kyle J. Rowley

A thesis submitted to the faculty of

Brigham Young University

in partial fulfillment of the requirements for the degree of

Master of Science

Rollin H. Hotchkiss, Chair

A. Woodruff Miller

Jani Radebaugh

Alan K. Zundel

Department of Civil and Environmental Engineering

Brigham Young University

August 2014

Copyright () 2014 Kyle J. Rowley

All Rights Reserved 


\author{
ABSTRACT \\ Sediment Transport Conditions Near Culverts \\ Kyle J. Rowley \\ Department of Civil and Environmental Engineering, BYU \\ Master of Science
}

Relatively little work has been done to understand how coarse grained sediments behave near culverts. Particularly for embedded culverts, sediment transport must be understood to achieve sustainable culvert designs for aquatic organism passage and peak discharge requirements. Several culvert sites in the Wasatch Mountains of Utah were studied through the spring flood season of 2014. Data obtained from the culvert sites were used to create numerical models with the Sedimentation and River Hydraulics Two-Dimensional model. The field sites and numerical model were used to study deposition of sediments at the entrance to culverts, sediment replenishment inside culverts, and lateral fining within the culvert barrel. Each element of the study was observed in the field. It was shown that the Sedimentation and River Hydraulics Two-Dimensional model is a useful tool to simulate the observed phenomenon of sediment deposition upstream of culverts, sediment replenishment, and lateral fining. Sedimentation and River Hydraulics Two-Dimensional model should be used in culvert design procedures as a means to understand sediment transport conditions.

This work documents the first time that deposition of sediments upstream of a culvert and lateral fining within a culvert barrel have been successfully modeled. The work shows that culvert replenishment occurs naturally in many scenarios and should be simulated as part of the culvert design process. The results from this work will be useful for future design guidelines for culvert installations.

Keywords: culverts, culvert replenishment, sediment transport, Stream Simulation, HEC-26, lateral fining, lateral sorting, sediment deposition. 


\section{ACKNOWLEDGEMENTS}

I would like to especially thank my family for their help, support, and encouragement to complete my degree. I am thankful for the help of my advisor, Dr. Rollin H. Hotchkiss, and the faculty of Brigham Young University for their guidance, teachings, and suggestions. The work contained in this thesis required extensive hours in the field, and I want to especially thank Evan Cope, Dan Jones, and Fernando Rivera for consistently being willing and able to help. I would also like to recognize Matt George, Ryan Egbert, Keelan Jensen, Ed Kern, Ryan Woods, and Lawrence Pico for their contributions to the field work. I am grateful to Alan K. Zundel and Aquaveo for their support of my education and for providing resources to assist me with the numerical modeling. 


\section{TABLE OF CONTENTS}

LIST OF TABLES ................................................................................................................ vi

LIST OF FIGURES

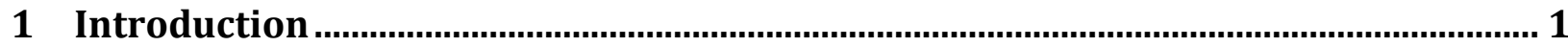

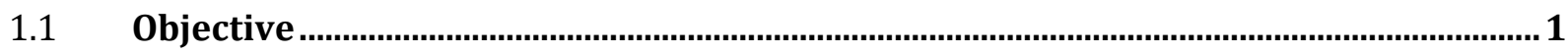

1.2 Scope

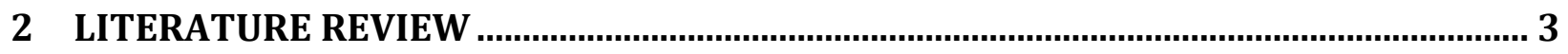

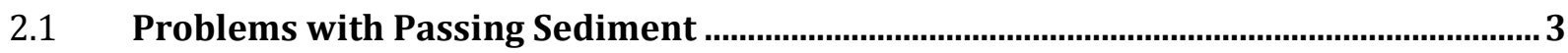

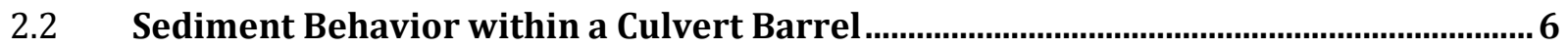

2.3 Effects of Turbulence and Velocity Distributions in Culverts ....................................... 9

2.4 Current Design Guidelines for Embedded Culverts ..................................................... 12

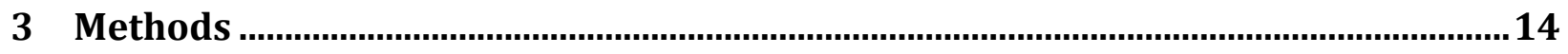

Research Locations and Descriptions ....................................................................... 14

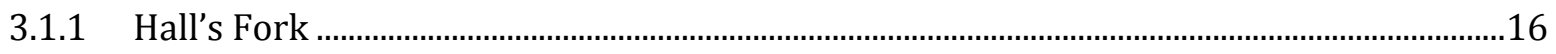

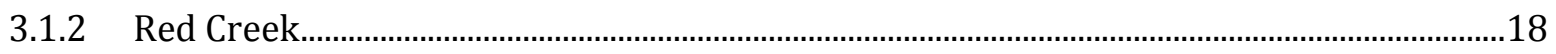

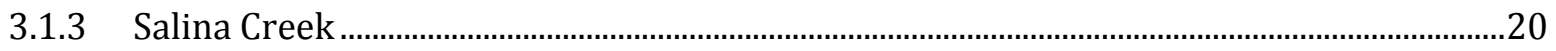

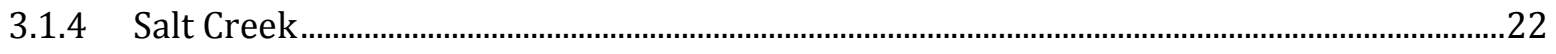

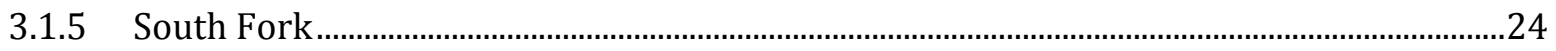

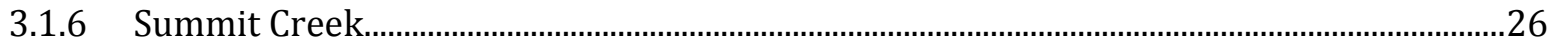

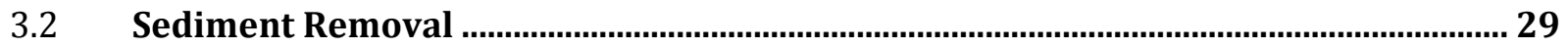

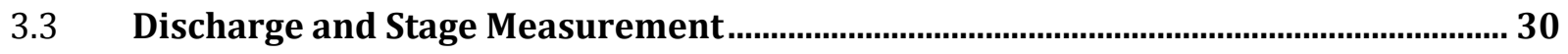

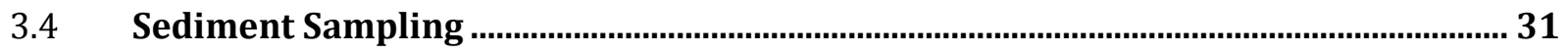

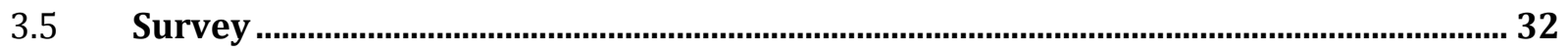

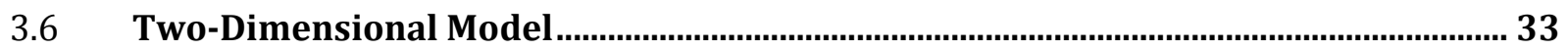




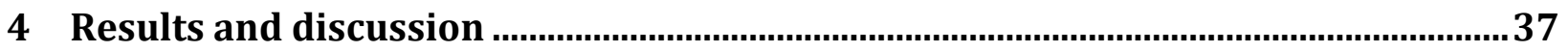

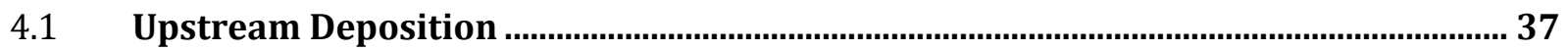

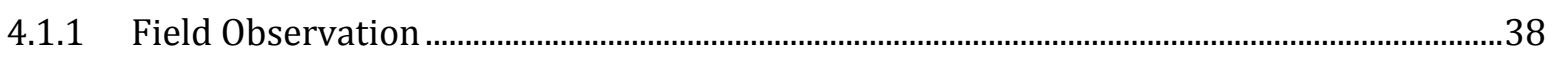

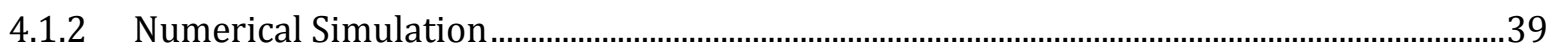

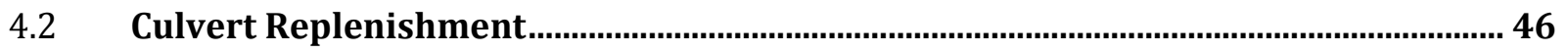

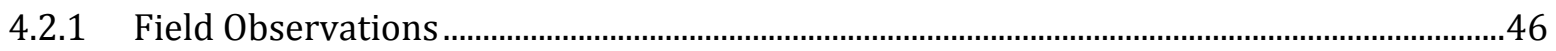

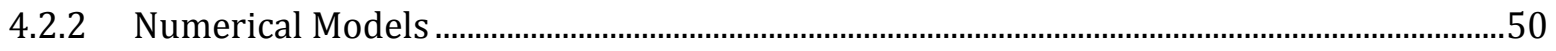

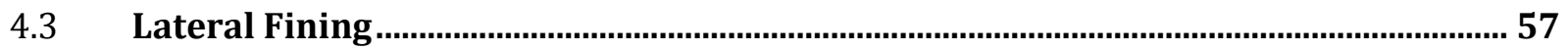

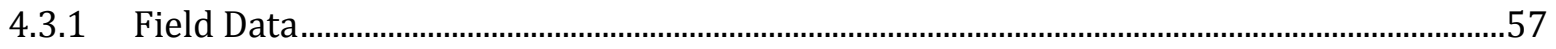

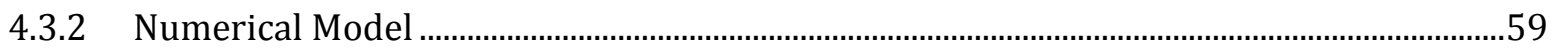

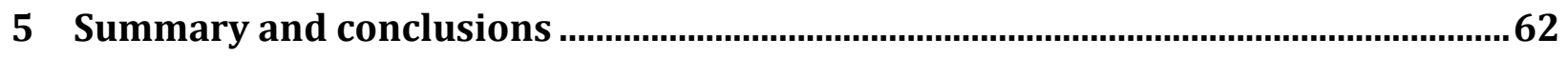

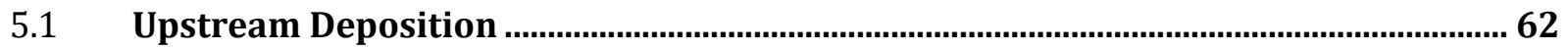

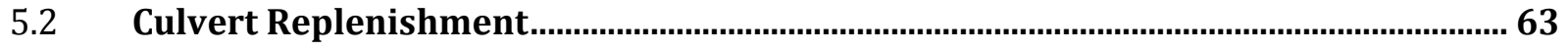

$5.3 \quad$ Lateral Fining

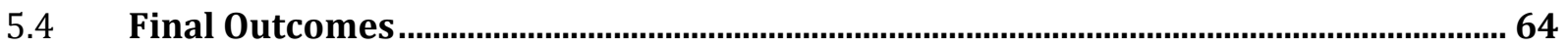

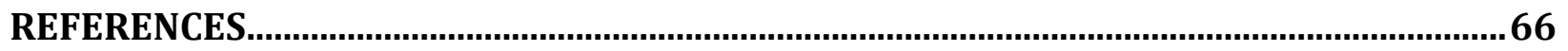

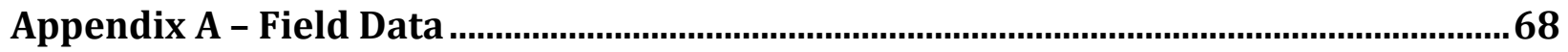

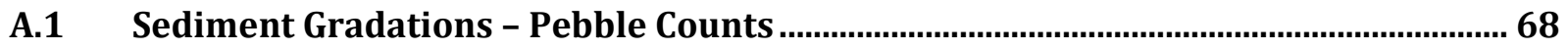

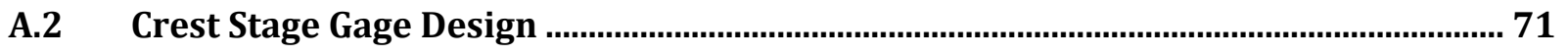

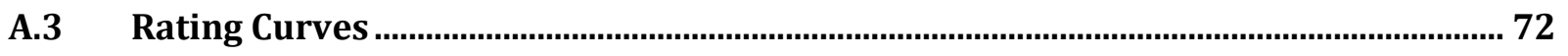




\section{LIST OF TABLES}

Table 3-1: Culvert Location and Upstream Basin Area.................................................... 15

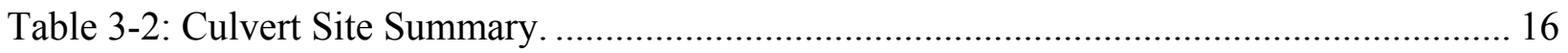

Table 3-3: Sediment Gradation for Each Site Expressed in Millimeters................................... 16

Table 3-4: Comparison of Maximum Observed Flow to Stream Regression Flows for Various Flood Return Periods (Kenney 2008)......................................................................... 31

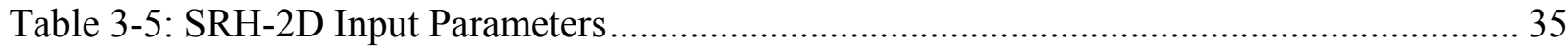

Table 4-1: Observation and Simulation Results Summary for Deposition of Sediments at a Culvert Entrance.

Table 4-2: Maximum Sediment Deposition from SRH-2D Simulations for Hall's Fork............ 51

Table 4-3: Maximum Sediment Deposition from SRH-2D Simulations for Red Creek............. 52

Table 4-4: Maximum Sediment Deposition from SRH-2D Simulations for Salt Creek. ............ 53

Table 4-5: Maximum Sediment Deposition from SRH-2D Simulations for South Fork........... 55

Table 4-6: Review and Summary of Observed and Simulated Culvert Replenishment............. 56

Table 4-7: Comparison of $\mathrm{D}_{50}$ Sediment Size for Field Data and Numerical Model Simulations.

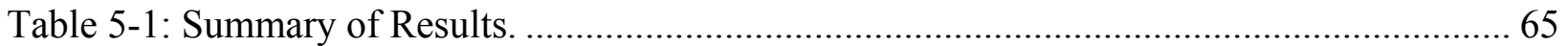




\section{LIST OF FIGURES}

Figure 2-1: Culvert Failure Mechanisms at Stream Crossings in Northwestern California

(Cafferata 2004).

Figure 2-2: Comparison of Headloss Magnitude for Sediment Laden Flow versus Clear Flow for the Armagosa Creek Culvert. Note: Metric Units Are Used in the Figure (Tsihrintzis 1995).

Figure 2-3: Model of Vertical Contraction Scour (Hahn and Lyn 2010)...................................... 9

Figure 3-1: Map Illustrating Culvert Study Locations.............................................................. 15

Figure 3-2: Hall's Fork Culvert Downstream Invert (Photo taken by Ryan Woods). ................... 17

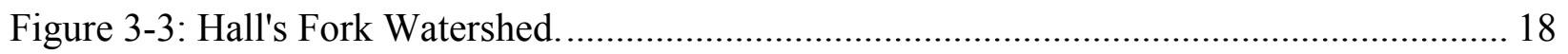

Figure 3-4: Red Creek Culvert Downstream Invert Looking Upstream........................................ 19

Figure 3-5: Red Creek Watershed and Culvert Location.......................................................... 20

Figure 3-6: Salina Creek Culvert from Upstream Reach Looking Downstream........................... 21

Figure 3-7: Salina Creek Watershed and Culvert Location............................................................ 22

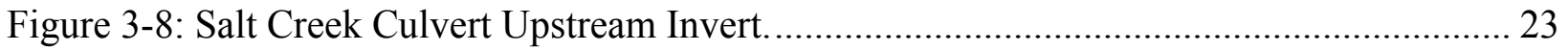

Figure 3-9: Salt Creek Watershed and Culvert Location................................................................ 24

Figure 3-10: South Fork Culvert from Upstream Reach Looking Downstream. .......................... 25

Figure 3-11: South Fork Watershed and Culvert Location........................................................... 26

Figure 3-12: Summit Creek Culvert Downstream Invert. ............................................................ 27

Figure 3-13: Summit Creek Watershed and Culvert Location. ................................................... 28

Figure 3-14: Ed Kern, Dan Jones, and Evan Cope Work to Remove Sediments from the Summit Creek Culvert Barrel. ...................................................................................... 30

Figure 3-15: A Portion of the Mesh Used to Simulate the Hall's Fork Culvert. Flow Would Be from Bottom to Top. (Mesh Created using SMS v 11.1) ................................................ 33

Figure 4-1: Topology of Upstream Deposition of Sediments.................................................... 38

Figure 4-2: Deposition at the Salt Creek Culvert Entrance. ............................................................ 39

Figure 4-3: Simulation of Upstream Sediment Deposition for 2-year Flood. .............................. 40 
Figure 4-4: Simulation of Upstream Sediment Deposition for 5-year Flood ........................... 40

Figure 4-5: Simulation of Upstream Sediment Deposition for 25-year Flood. ......................... 41

Figure 4-6: Simulation of Upstream Sediment Deposition for 2-year Flood. ........................... 42

Figure 4-7: Simulation of Upstream Sediment Deposition for 5-year Flood. ........................... 42

Figure 4-8: Simulation of Upstream Sediment Deposition for 25-year Flood. …..................... 43

Figure 4-9: Simulation of Upstream Deposition for 2-year Flood. ....................................... 44

Figure 4-10: Simulation of Upstream Deposition for 5-year Flood. ....................................... 44

Figure 4-11: Simulation of Upstream Deposition for 25-year Flood. ..................................... 45

Figure 4-12: Sediment Deposits Found in Salt Creek Culvert Following High Flows.............. 47

Figure 4-13: Sediments Deposited in the Salt Creek Culvert Barrel. ........................................ 48

Figure 4-14: Small Boulder Settled inside the Summit Creek Culvert................................... 49

Figure 4-15: Fine Sediments Hiding Behind Flow Obstruction. ........................................ 50

Figure 4-16: Sediment Depositional Depths for the 2-, 5-, and 25- year Floods in Feet from

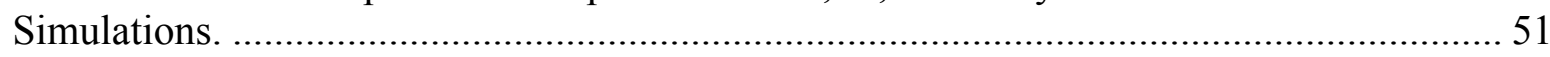

Figure 4-17: Mean Sediment Diameter for 2-, 5-, and 25-year Floods in Millimeters from

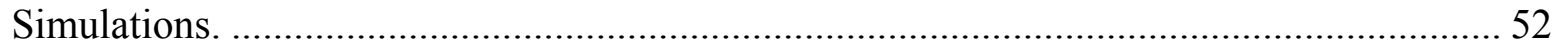

Figure 4-18: Deposition (left) in Feet and Mean Sediment Size in Millimeters (right) for the Red Creek Culvert with 25-year Flood Conditions from Simulations. ............................ 53

Figure 4-19: Sediment Depositional Depth for the 2-, 5-, and 25-year Floods Given in Feet

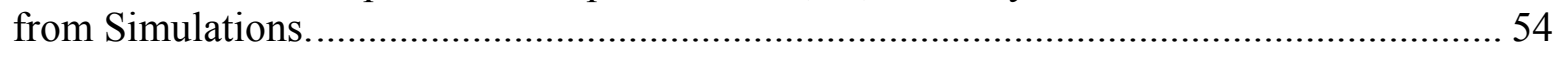

Figure 4-20: Mean Sediment Diameter in Millimeters for the 2-, 5-, and 25-year Floods from Simulations. 54

Figure 4-21: Sediment Depositional Depth in Feet for the 2-, 5-, and 25-year Flood from Simulations. 55

Figure 4-22: Mean Sediment Diameter in Millimeters for the 2-, 5-, and 25-year Flood from Simulations. 56

Figure 4-23: Plan View of Salina Creek Culvert: Sediment Sample Locations in North Barrel

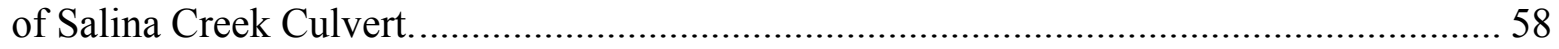

Figure 4-24: Sediment Gradation from Lateral Samples taken from Salina Creek. 59 
Figure 4-25: Plan View of Salina Creek Culvert: Mean Sediment Diameter in Millimeters for the 2-year Flood Obtained from the Simulation.

Figure 4-26: Plan View of Salina Creek Culvert: Mean Sediment Diameter in Millimeters for the 5-year Flood Obtained from the Simulation. ............................................................ 60

Figure 4-27: Plan View of Salina Creek Culvert: Mean Sediment Diameter in Millimeters for the 25-year Flood Obtained from the Simulations............................................................ 61

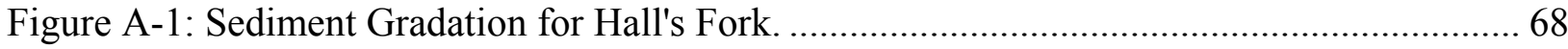

Figure A-2: Sediment Gradation for Red Creek. ............................................................... 69

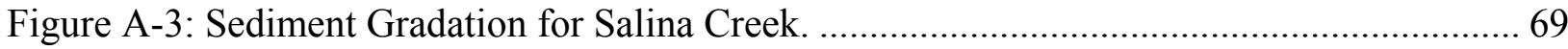

Figure A-4: Sediment Gradation for Salt Creek. ................................................................. 70

Figure A-5: Sediment Gradation for South Fork............................................................ 70

Figure A-6: Crest-Stage Gage Design (USGS 2010). ........................................................ 71

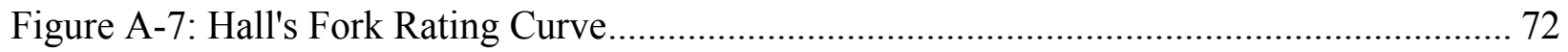

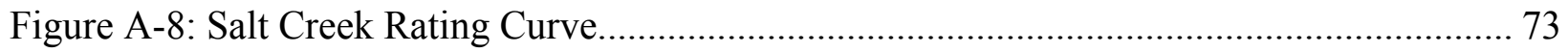

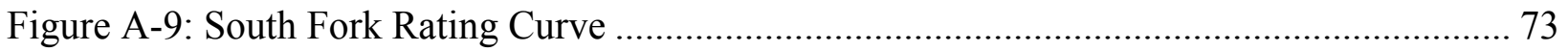

Figure A-10: Summit Creek Rating Curve. ......................................................................... 74 


\section{INTRODUCTION}

\subsection{Objective}

The purposes of this research are to simulate (1) the deposition that frequently occurs in coarse-bedded streams at the entrance to culverts; (2) the conditions under which sediment is expected to replenish the culvert barrel with additional substrate; and (3) the process of lateral fining within the culvert barrel. Sediment transport will constantly occur through the rivers and reaches where culverts are placed as a means of stream crossings. Newer culvert installations have been designed to have substrate placed within the barrel to facilitate aquatic organism passage (Kilgore 2010), but the nature of sediment transport in the vicinity of culverts is largely unknown.

Field data and numerical models were used to simulate and reproduce deposition upstream of culverts, the replenishment that can occur within a culvert from upstream sediment transport, and the lateral fining that can occur within the culvert barrel. Several culverts were selected for the study in the Wasatch Mountains of Utah on various stream sizes. Sedimentation and River Hydraulics Two-Dimensional model (SRH-2D) was used to numerically simulate each site studied.

\subsection{Scope}

The culverts described in this report are located on mountain streams in the Wasatch Mountains of Utah. The streams studied have gravel beds with culverts that were not designed 
for embedment. However, each of the culverts considered was selected because sediment had been transported and deposited into or near the barrel.

The following sections are presented:

- A literature review of flow and sediment transport characteristics in the vicinity of culverts

- Field measurements and methods used to study upstream sediment deposition, culvert barrel replenishment, and lateral fining.

- Field and numerical model results.

- Conclusions and recommendations. 


\section{LITERATURE REVIEW}

\subsection{Problems with Passing Sediment}

While culverts have traditionally been designed to pass a given discharge of water, sediment transport through culvert structures has been a recognized problem for many years. Over one hundred years ago, William H. Haight of Minnesota submitted a patent for a culvert with special design features for passage of sediment and ice (Haight 1912). The passage of sediment continues to be a problem at stream crossings.

The state of California issued a report in 2004 stating that sediment plays a role in $25 \%$ of culvert failures, second only to woody debris, while very few failures are a result of hydraulic exceedance (Figure 2-1). The report states, "it remains difficult to directly predict the loading of sediment and wood at a given crossing, but we can design crossings to better accommodate these watershed products and reduce the risk of failure." The report suggests that culverts be designed with a headwater depth to culvert diameter ratio (HW/D) of values less than 1.0 and that diameters be increased so as to accommodate the active channel width (Cafferata 2004). 


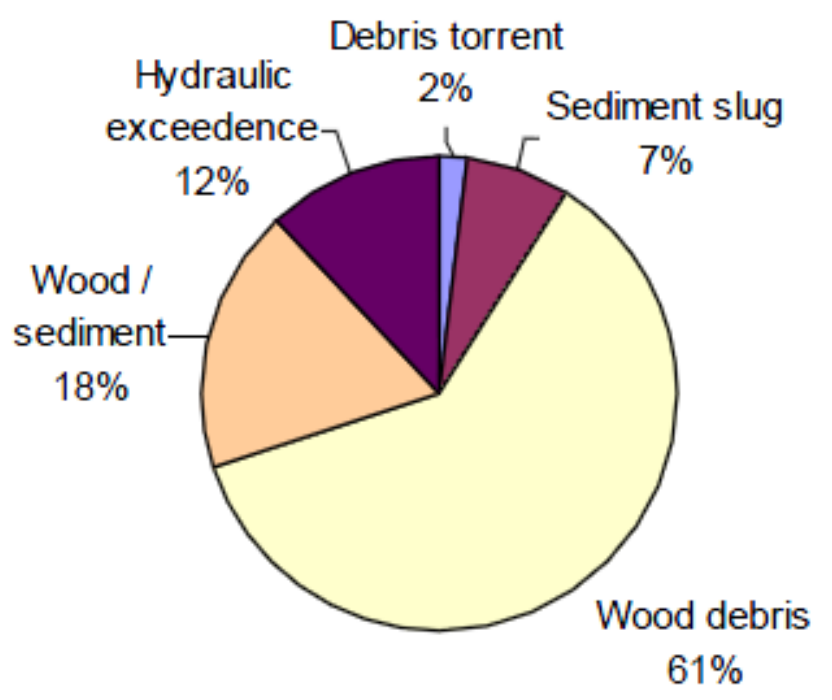

Figure 2-1: Culvert Failure Mechanisms at Stream Crossings in Northwestern California (Cafferata 2004).

Wellman et al. (2000) observed gravel bars within box culverts following high flows in the State of Tennessee. The bars were understood to occur due to an inconsistency between the slope of the culvert and the slope of the streambed. The outlet invert of the culvert dropped below the stream bed creating a backwater portion in the barrel. The backwatered area allowed for small particles to deposit, build, and stabilize a sediment structure through high flows (Wellman et al. 2000). Tsihrintzis (1995) cited the events that occurred on Armagosa Creek in the early 1990s when flood flows carrying large amounts of sediment left deposits above the inlet and in the entrance of the culvert. City crews attempted to raise the headwater of the culvert with sandbags in an effort to flush the deposited sediments. The effect was reversed, and sediment deposits continued to build until the culvert inlet was completely plugged. When the peak flows were compared with the design flow of the culvert, it was discovered that the peak flow was approximately $2000 \mathrm{cfs}$, but the design discharge was $6000 \mathrm{cfs}$, supposedly at the same 
headwater depth. Part of the trouble associated with the culvert design was that the headloss of the sediment laden water from flood flows was very different from the headloss associated with clear water flows (Figure 2-2 Shown with Metric Units).Therefore the design using clear water resulted in a culvert unable to move sediments through the system. Tsihrintzis stressed the need for a sediment transport study to be conducted with each culvert installation and for design flows to account from sediment flow as well as clear water flow (Tsihrintzis 1995).

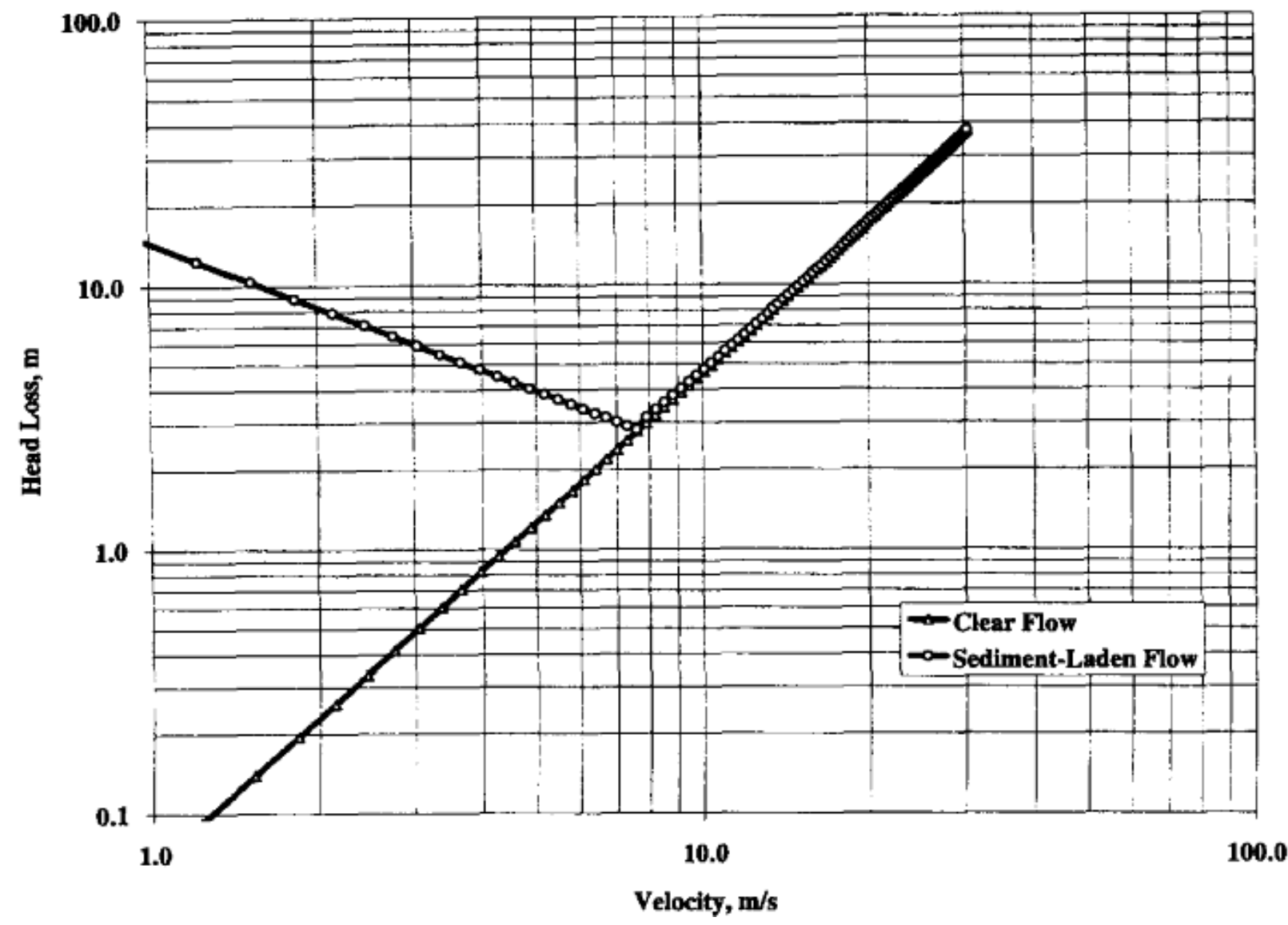

Figure 2-2: Comparison of Headloss Magnitude for Sediment Laden Flow versus Clear Flow for the Armagosa Creek Culvert. Note: Metric Units Are Used in the Figure (Tsihrintzis 1995).

Wargo and Weisman (2006) discussed the unforeseen effects associated with the installation of a single culvert barrel for conveyance on small streams. Channel dimensions are 
typically associated with the dominant discharge — often with the 1.5 year recurrence interval flood. However, culverts are designed for passage of a much higher event, such as the 25 or 50 year flood (ODOT 2011). During such large floods, flow in the floodplain upstream from the culvert must contract and pass through the culvert barrel. The decrease in channel dimensions causes the stream to deposit the bedload sediments upstream of the culvert entrance as the flow contracts and backs up (Wargo and Weisman 2006).

Recent research has encouraged the use of multi-cell, or staggered barrel, culverts for stream crossings. The design incorporates the use of multiple culvert barrels of different sizes placed in the embankment material at various elevations and stations. Each culvert in the design is characterized as a channel culvert or a floodplain culvert. The idea suggests that the sediment transport regime would not be disrupted as is the case with a single barrel design because the culvert setup mimics the stream and floodplain configuration (Wargo and Weisman 2006).

\subsection{Sediment Behavior within a Culvert Barrel}

Sediment moves in response to the flow of water. Within a culvert barrel sediment behaves and reacts much differently than it would outside of the culvert barrel for a given flow. Much of this is due to the relatively smaller culvert cross section and the possibility of pressure flow. Both scour and pressure flow as they relate to culverts will be reviewed to help understand the possibility of deposited sediment in culvert barrels being transported out of the culvert, leaving the barrel material exposed following the scour event.

Research has advanced in the study of scour through contractions and work has been done to find the maximum scour depth or how to compute the maximum scour depth for a given set of parameters. For example, work by Gill suggests that the so-called Straub one-dimensional 
model is accurate for long contractions (Gill 1981), and Lim and Cheng (1998) have suggested that for bridges the maximum scour depth is a function of the contraction ratio. However, others have suggested that there is not an absolute scour depth, but that scour may continue to grow in an asymptotic manner (Hahn and Lyn 2010). For closed bottom culverts the maximum scour depth is controlled by the dimensions of the structure itself.

Kerenyi and Pagán-Ortiz (2007) investigated the potential for scour near the inlet of open bottom culverts. They set up a flume experiment with a model culvert 1.96 feet wide and 5.25 feet long. A discharge of $10 \mathrm{cfs}$ was passed through the culvert. A scour map was created using a laser distance sensor. The group noted that the largest scour occurs near the inlet at the corners and at the outlet of the culvert. The scour is attributed to the vortices and turbulence levels created as the flow contracts through the culvert opening. Scour occurring at bridge abutments is formed in the same way as the scour at the contraction corners of culverts. While the group found that culvert shape did not significantly influence scour, the entrance conditions did. The research suggests that the use of a 45 degree inlet wing wall will decreases the scour at the upstream corners (Kerenyi and Pagán-Ortiz 2007).

Dey and Raikar showed that scour is also a function of the gradation of the bed materials. Uniform bed sediments scour more rapidly and at greater depths than do poor gradations. The poor gradations are able to form an armor layer by interlocking variable sediment sizes. The armor layer protects the other smaller particles underneath from scour (Dey and Raikar 2005).

With rising headwater and tailwater depths, pressure flow through a culvert barrel encounters a new type of scour, and sediment will interact uniquely with the natural streambed. When describing sediment transport through a culvert under pressure flow, Tsihrintzis outlined four possible sediment flow possibilities: (1) Homogeneous flow occurs when sediment particles 
are nearly uniformly distributed in any part of the cross section of flow. (2) Heterogeneous flow is similar to homogenous flow in that all of the particles are in suspension; however, the concentration of particles is not uniform in the vertical axis of the cross section. (3) Moving-bed flow exhibits saltation with ripples and dunes at the interface between the water and sediment. (4) Stationary bed flow has an immobile bed on the bottom of the culvert; thus reducing the area of actual flow with little sediment transport (Tsihrintzis 1995).

Hahn and Lyn (2010) conducted a study to measure clear water scour, that is, scour when there is no sediment transport from upstream, through a vertical contraction, causing pressure flow. The team set up the study in a flume at the Purdue Hydrodynamics Laboratory. With a set ratio of lower chord height $\left(\mathrm{H}_{\mathrm{b} 0}\right)$ to headwater depth $\left(\mathrm{H}_{\mathrm{up}}\right)$ set to 0.78 as shown in Figure 2-3, the group tested the location of scour with two velocities of 0.748 and 0.840 feet per second. For both cases, the maximum depth of scour was observed downstream of the structure. The results obtained from Hahn and Lyn suggest that scour may not be as great within a culvert as it is downstream of the structure (Hahn and Lyn 2010). 


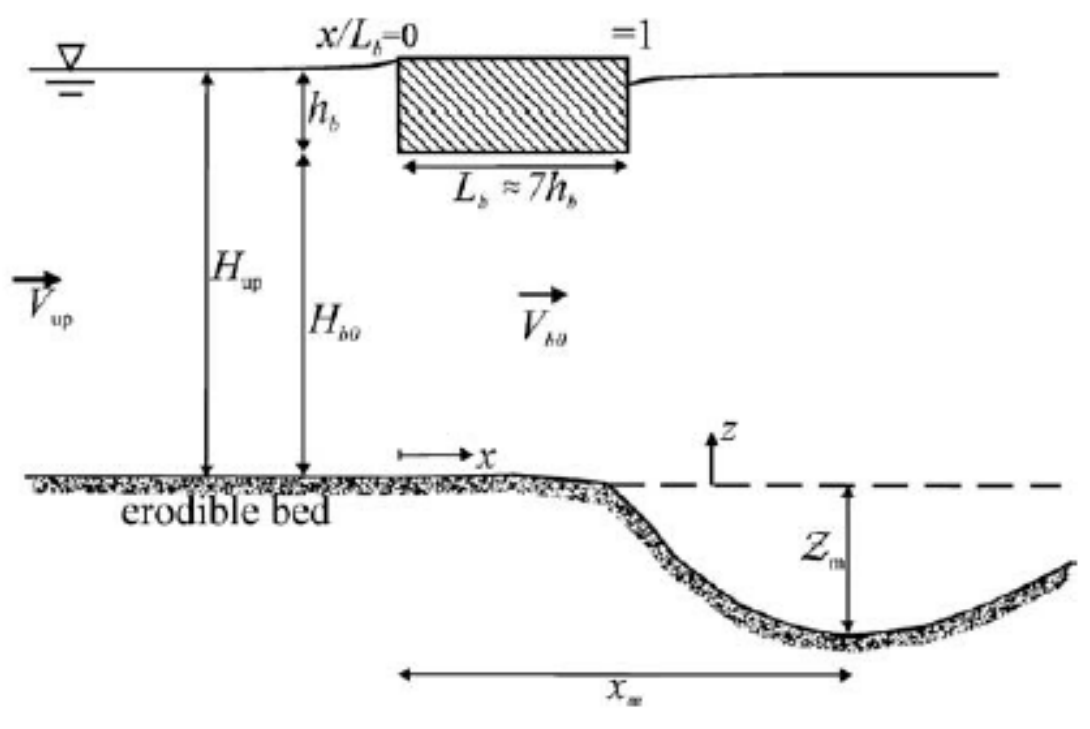

Figure 2-3: Model of Vertical Contraction Scour (Hahn and Lyn 2010).

While a number of physical models have been constructed to understand and predict scour, now, numerical models are entering the study field as a means to predict scour depths and locations. Lai and Greimann found that a two-dimensional, depth-averaged model, SRH-2D, was adequate for predicting scour depth. Lai concluded that the two-dimensional model was as effective as tests that were conducted using a three-dimensional model; nevertheless, the author reported that downstream aggradation following the expansion was less satisfactory with the two-dimensional model when compared with the three-dimensional model (Lai and Greimann 2010).

\subsection{Effects of Turbulence and Velocity Distributions in Culverts}

Recently studies have been conducted to find how velocities and turbulence values are unique in a culvert and through the culvert cross section. The differences in the velocity and turbulence inside the culvert as compared to the stream channel partially account for the nature 
of sediment transport observed inside of culverts and help explain deposition within the barrel. Lateral sorting inside a culvert has been observed and will be discussed with related research. Culverts vary in shape, size, and material, but Richmond et al. (2007) found that spiral corrugated metal pipe culverts produce unique turbulence characteristics independent of size and shape. An experiment was designed at the Washington Department of Fish and Wildlife Facility on Skookumchuck River near Tenino, Washington. The test was set up with a 40 feet long culvert, 6 feet in diameter, on a $1.14 \%$ slope. The corrugations were arranged with a wavelength of 0.25 feet and amplitude of 0.083 feet. Using an Acoustic Doppler Velocimeter, measurements were taken at six locations to quantify the magnitude and direction of velocity and turbulence. The test showed that secondary flows associated with the spiral corrugations caused irregularities in the velocity and turbulence distributions. The irregularities contributed to a reduced velocity zone on the left size when looking downstream (Richmond et al. 2007). Reduced velocity and turbulence regions allow for sediment to deposit when compared with higher velocities from the right side.

Ead et al. (2000) also did work to understand the turbulence characteristics in a culvert with an open channel flow regime. A test culvert was set up in a laboratory setting with a diameter of 0.622 meters. A range of flows were run through the culvert ranging from 0.7 to 10.6 cubic feet per on three different slope arrangements. Centerline velocity distributions were measured at 14 locations. The experiments demonstrated that flow through a culvert may not represent the typical log law velocity profile. Reduced velocity regions were found near the boundary layer of the culvert pipe .

Sediments are commonly sorted in rivers by size, shape, and density. The gravitational forces, hydraulic variables, such as boundary shear stress and turbulence diffusion, and the 
physical characteristics of the sediment and the fluid, such as the settling rates of particles and the density of the fluid and particles, come together resulting in the fining phenomena that is observed in the field (Brush 1960). Sediment sorting may be manifest in a variety of scenarios such as downstream fining, median size variation in pools compared with riffles of the same reach, variable size distributions across meander bends, downbar fining of braided rivers, and the sorting process associated with armor layer development (Powell 1998).

Powell described sorting during entrainment, transport, and deposition. Sorting during entrainment occurs because larger particles have greater inertia than smaller particles; thus they require higher magnitudes of tangential shear stress. Powell also considers the relationship between larger and smaller particles in terms of the ability for smaller particles to 'hide' with respect to larger particles at entrainment. The 'hiding factor' associated with particle entrainment complicates the sorting processes and leads to the equal mobility hypothesis which is "that under equilibrium transport conditions, surface coarsening through vertical winnowing acts to equalize the mobility of different sizes by counterbalancing the intrinsic lesser mobility of relatively coarse particles" (Parker et al. 1982).

Sorting during transport is due primarily to the changes associated with the channel bed and geometry. As the cross section changes or the channel curves additional forces combine to act on particles in transport. For example, in meander bends, smaller particles are forced inward due to secondary currents and larger particles slip down the slope of the bed in the bend (Powell 1998). Yen and Lee investigated the effects of the ramping rate of the hydrograph to the level of sorting within a meander bend. The team set up a flume experiment, with a 180 degree meander bend and a constant radius of curvature, to measure the degree of sorting due to the changes in the flow hydrograph. They concluded that a higher ramping rate of the hydrograph increases the 
movement of finer particles to the inner bank and increases the size of the coarser material on the outer bank of the cross section through a bend (Yen and Lee 1995).

Powell suggests that sediment sorting at deposition follows the patterns found along the bed. Therefore, coarse particles are less likely to deposit on fine beds where they would be exposed to greater magnitudes of drag in comparison with the drag forces on beds of similar grain size. Secondly, the turbulence that accompanies a bed of more coarse particles will prolong the transport of smaller grains past the coarse bed (Powell 1998).

Research has provided many insights relating to the nature of sediment sorting and scour. However, more specific work must be done to better define the nature of sediment transport in the vicinity of culverts. A number of variables relating to sediment transport near culverts have been left unexplored, and the resources to investigate these variables are relatively undeveloped.

\subsection{Current Design Guidelines for Embedded Culverts}

Both the Federal Highway Administration and the U.S. Forest Service have separate and unique design guidelines for embedded culverts; however, both design standards prioritize aquatic organism passage as a primary objective. Each uses culvert embedment of some type as a means to ensure and promote the ability of aquatic organisms to migrate upstream or simply move within the culvert barrel.

HEC-26 is the design guideline sponsored by the Federal Highway Administration (Kilgore 2010). The design procedure uses stream sediment movement as the primary variable in the design process. To accomplish this task, the culvert barrel is designed large enough to maintain a stable bed of a given embedment depth through the design discharge. The authors of HEC-26 recognize that replenishment is possible and likely in some culvert applications. 
However, for simplicity and avoidance of a complex sediment transport analysis, a 'worst-case' assumption of no replenishment is assumed for all stream crossings and locations (Kilgore 2010). Stream Simulation written by the U.S. Forest Service considers stream crossings with a different perspective when compared with the specifics of HEC-26. Stream simulation suggests that if the bankfull dimensions on the natural reach can be maintained through the crossing structure, then the crossing will not be any more of an impediment to aquatic organisms as is the natural channel where they live. The design relies on sediment replenishment suggesting that it will naturally occur since the structure is to encompass the active dimensions of the reach (USFS 2008). 


\section{METHODS}

In order to simulate the deposition that occurs upstream of a culvert installation, the conditions under which sediment is expected to replenish the culvert barrel, and the process of lateral fining, culverts on mountainous, coarse bedded streams were selected to be studied in conjunction with the numerical model SRH-2D. This chapter will discuss the efforts and methods of measurement that were undertaken to meet the research focus.

\subsection{Research Locations and Descriptions}

The phenomena described in the research focus are observed in many culverts. For research purposes, six culverts on various streams in the Wasatch Mountains were selected for the study. The culverts were selected based on their unique characteristics observed in the field and how the characteristics of each culvert could be used to study the upstream sediment deposition, culvert barrel replenishment, and the lateral fining associated with the contraction of the channel. Figure 3-1 shows each location within the State of Utah and Table 3-1 describes the location and the upstream basin area. 


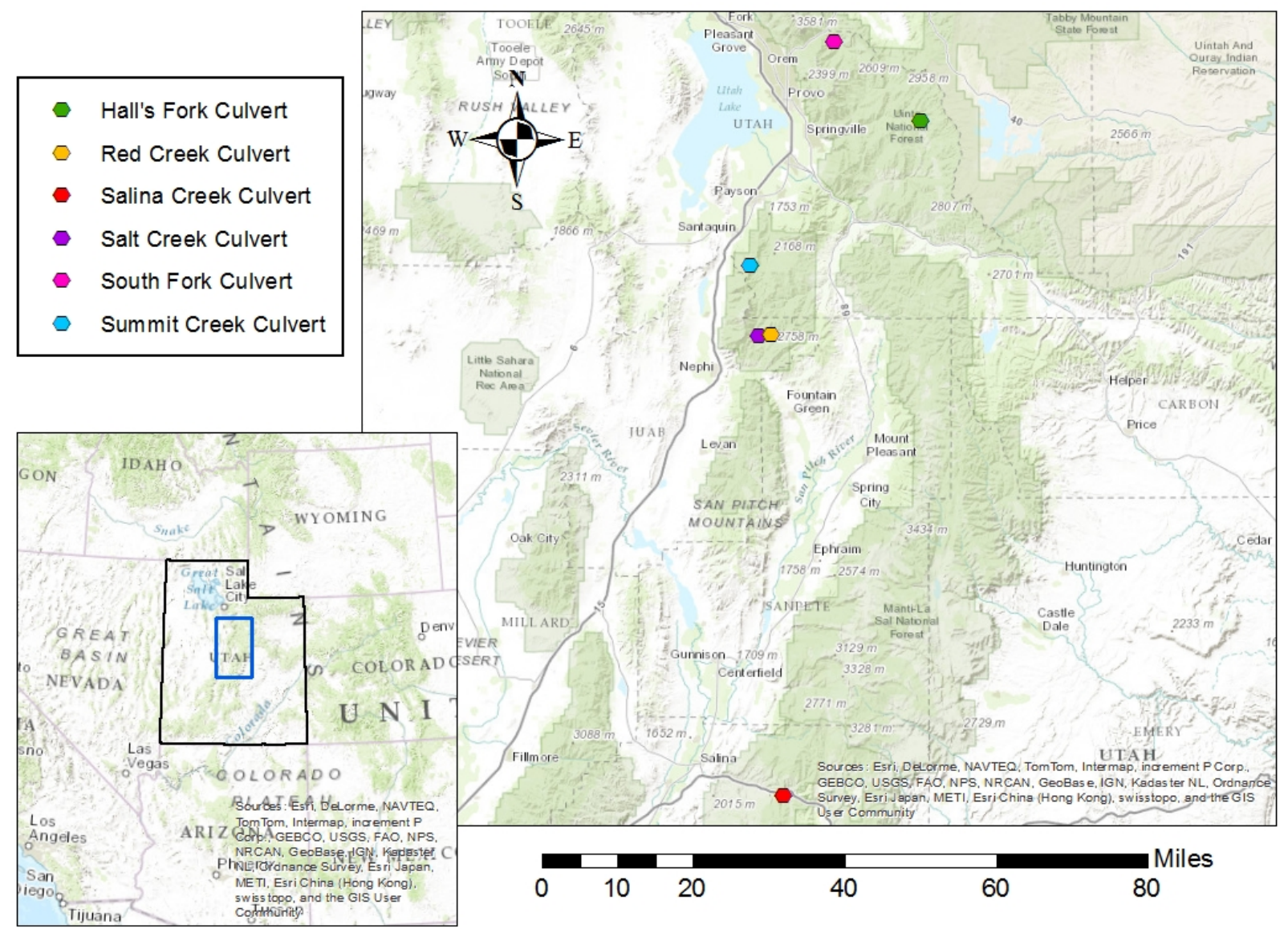

Figure 3-1: Map Illustrating Culvert Study Locations.

Table 3-1: Culvert Location and Upstream Basin Area

\begin{tabular}{lccc}
\hline $\begin{array}{c}\text { Culvert Site } \\
\text { Name }\end{array}$ & $\begin{array}{c}\text { Latitude } \\
{[\text { dec. degrees N] }}\end{array}$ & $\begin{array}{c}\text { Longitude } \\
{[\text { dec. degrees W] }}\end{array}$ & $\begin{array}{c}\text { Watershed Basin } \\
\text { Area }\left[\mathrm{mi}^{2}\right]\end{array}$ \\
\hline Hall's Fork & 40.1927 & 111.3241 & 4.7 \\
Red Creek & 39.7817 & 111.6921 & 1.5 \\
Salina Creek & 38.8976 & 111.6562 & 146.8 \\
Salt Creek & 39.7800 & 111.7238 & 13.0 \\
South Fork & 40.3463 & 111.5432 & 28.1 \\
Summit Creek & 39.9100 & 111.7405 & 14.0 \\
\hline
\end{tabular}


Each culvert barrel size, culvert barrel length, stream slope, culvert barrel slope, and streambed sediment size distribution is summarized in Table 3-2 and Table 3-3.

Table 3-2: Culvert Site Summary.

\begin{tabular}{|c|c|c|c|c|c|c|}
\hline & Shape & $\begin{array}{l}\text { Culvert } \\
\text { Material }\end{array}$ & $\begin{array}{l}\text { Length } \\
{[\mathrm{ft}]}\end{array}$ & $\begin{array}{c}\text { Cross } \\
\text { Section } \\
\text { Dimensions } \\
{[\mathrm{ft}]}\end{array}$ & $\begin{array}{l}\text { Culvert } \\
\text { Slope }\end{array}$ & $\begin{array}{c}\text { Average } \\
\text { Stream } \\
\text { Bed } \\
\text { Slope }\end{array}$ \\
\hline Hall's Fork & Pipe Arch & Steel CMP & 34 & $5.5 \mathrm{~h} 8 \mathrm{w}$ & 0.009 & 0.038 \\
\hline Red Creek & Circular & Steel CMP & 45 & 5 diam & 0.087 & 0.097 \\
\hline Salina Creek & $\begin{array}{c}\text { Box - } \\
\text { Double }\end{array}$ & Concrete & 39 & $10 \times 10$ & 0.0 & 0.011 \\
\hline Salt Creek & Pipe Arch & Steel CMP & 48 & $7 \mathrm{~h} 10 \mathrm{w}$ & 0.008 & 0.028 \\
\hline South Fork & Circular & Steel CMP & 30 & 6 diam & -0.003 & 0.020 \\
\hline Summit Creek & Pipe Arch & Steel CMP & 50 & $7 \mathrm{~h} 10.7 \mathrm{w}$ & 0.010 & 0.093 \\
\hline
\end{tabular}

Table 3-3: Sediment Gradation for Each Site Expressed in Millimeters.

\begin{tabular}{lccccc}
\hline & $\mathrm{D}_{15}$ & $\mathrm{D}_{50}$ & $\mathrm{D}_{84}$ & $\mathrm{D}_{95}$ & $\begin{array}{c}\text { Observed Depositional Pattern } \\
\text { Within Culvert Barrel }\end{array}$ \\
\hline Hall's Fork & 5 & 50 & 110 & 150 & Mostly near outlet \\
Red Creek & 14 & 55 & 260 & 360 & Mostly near outlet \\
Salina Creek & 14 & 75 & 290 & 400 & Mostly on left side of barrel \\
Salt Creek & 16 & 55 & 100 & 140 & Uniform through culvert length \\
South Fork & 15 & 30 & 80 & 120 & Mostly near inlet \\
\hline
\end{tabular}

\subsubsection{Hall's Fork}

The Hall's Fork basin lies in the upper reaches of Diamond Fork. The runoff is heavily supplemented by groundwater. The Hall's Fork stream meanders through a narrow valley relatively unrestricted by mountain slopes or roads. The culvert is pipe-arch in shape and has a drop built into the inlet. Historically, sediments were deposited on the downstream side of the culvert, and the deposition was influenced by a bed control formed by large rocks at the 
downstream invert (Figure 3-2). Figure 3-3 shows the Hall's Fork watershed and culvert location.

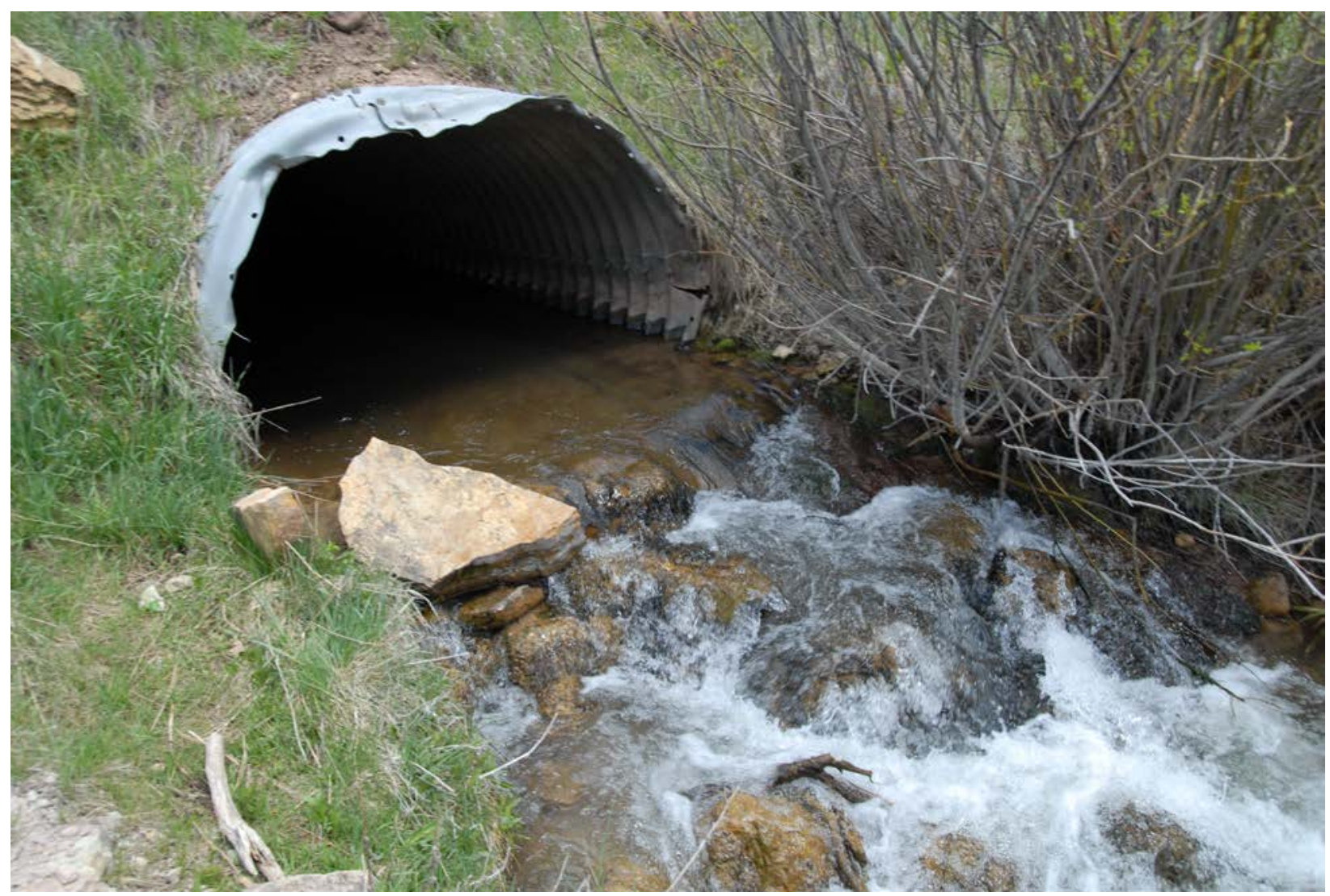

Figure 3-2: Hall's Fork Culvert Downstream Invert (Photo taken by Ryan Woods). 

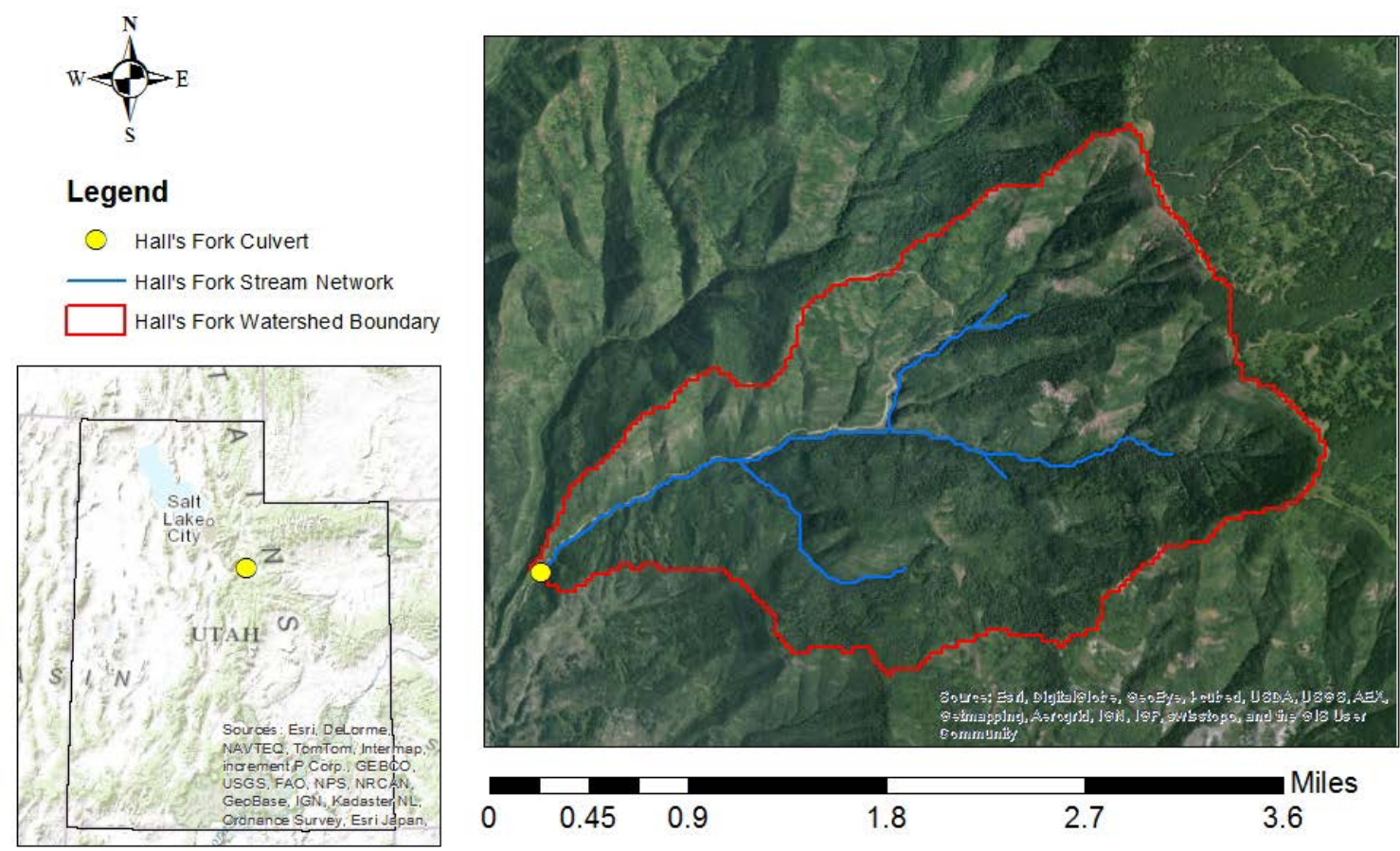

Figure 3-3: Hall's Fork Watershed.

\subsubsection{Red Creek}

Red Creek owes its name to the color of the water derived from the upper reaches of the watershed. The stream is constricted by steep mountain walls on either side. The Red Creek culvert is a long, circular corrugated metal pipe with a flared end section at the upstream invert. The culvert is shown in Figure 3-4. A map of the watershed basin and culvert location is given in Figure 3-5. 


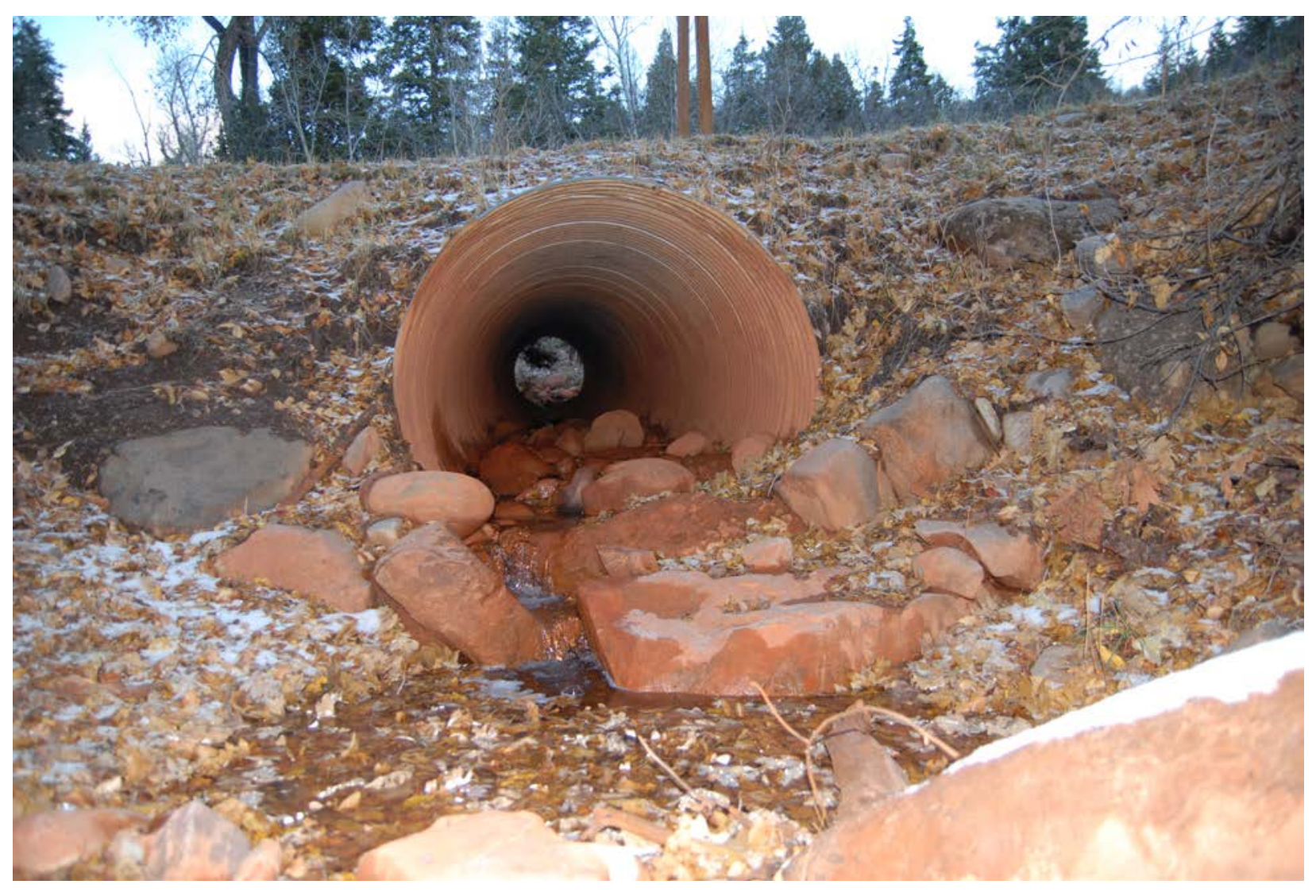

Figure 3-4: Red Creek Culvert Downstream Invert Looking Upstream. 


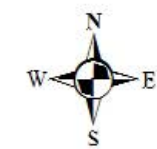

Legend

Red Creek Culvert
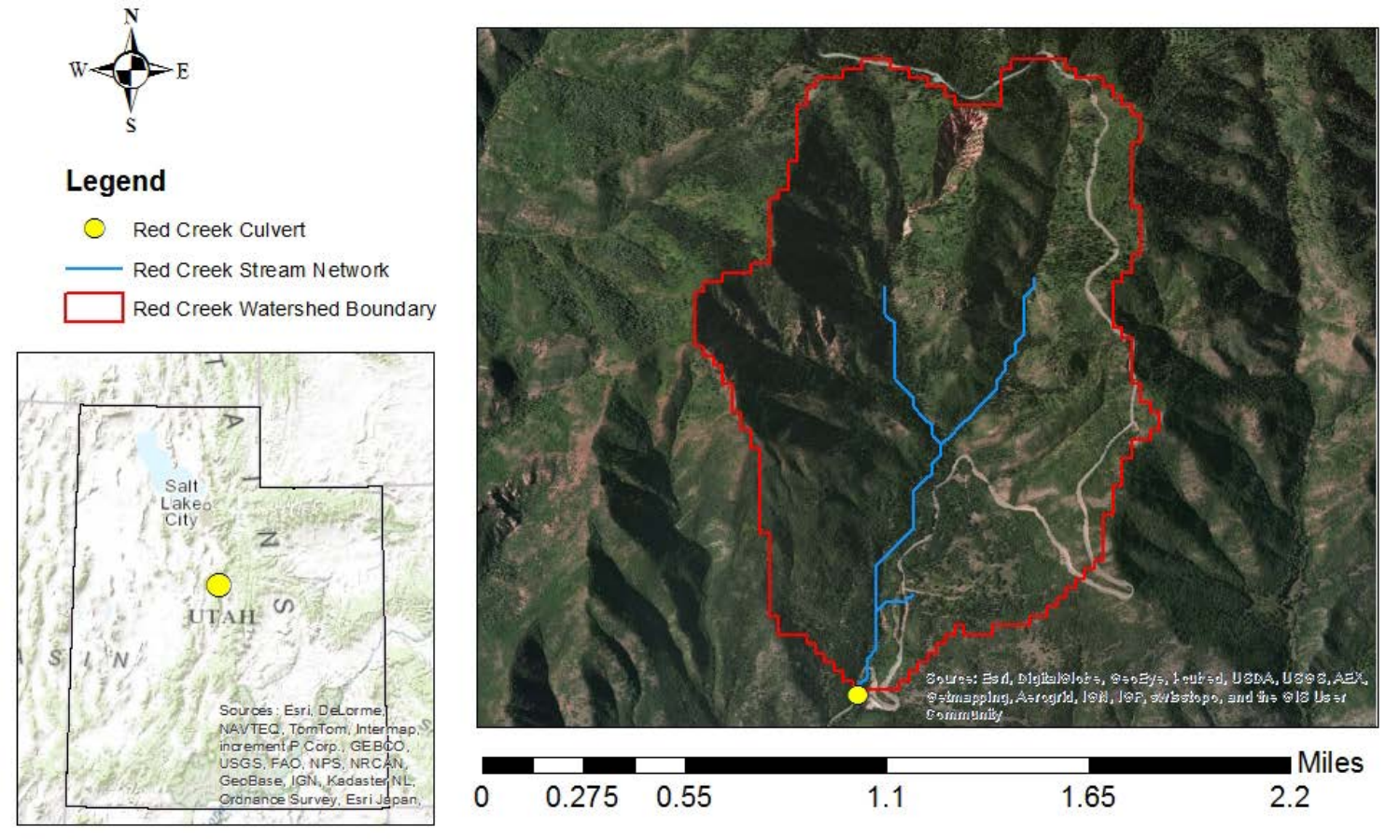

Figure 3-5: Red Creek Watershed and Culvert Location.

\subsubsection{Salina Creek}

Salina Creek is the largest river and culvert of all the sites studied. The creek has an extensive watershed with a basin area of 146.8 square miles. The culvert is a double barrel concrete box with a cast in place headwall and wing walls, and is shown in Figure 3-6. A map of the Salina Creek watershed and location is given in Figure 3-7. 


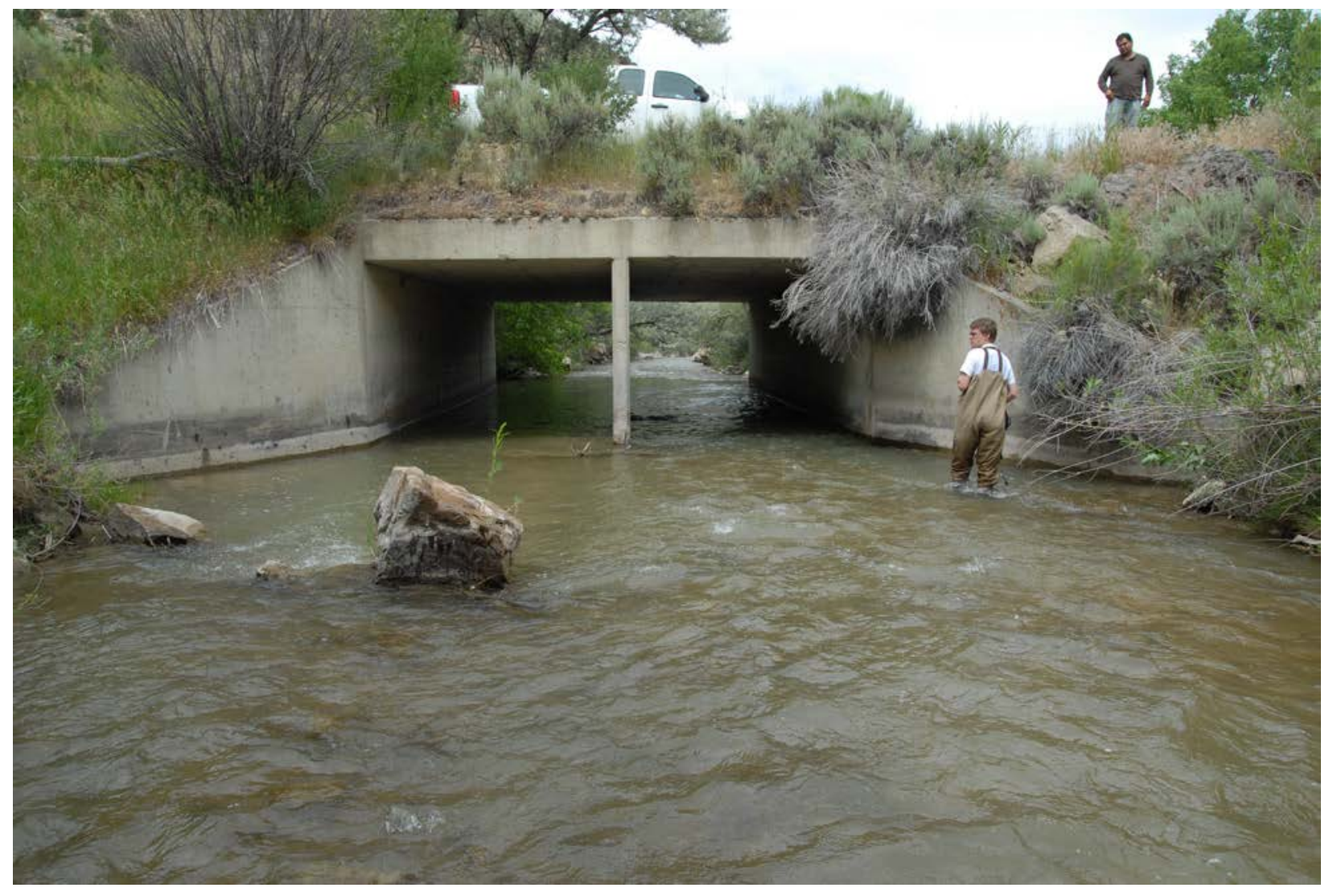

Figure 3-6: Salina Creek Culvert from Upstream Reach Looking Downstream. 

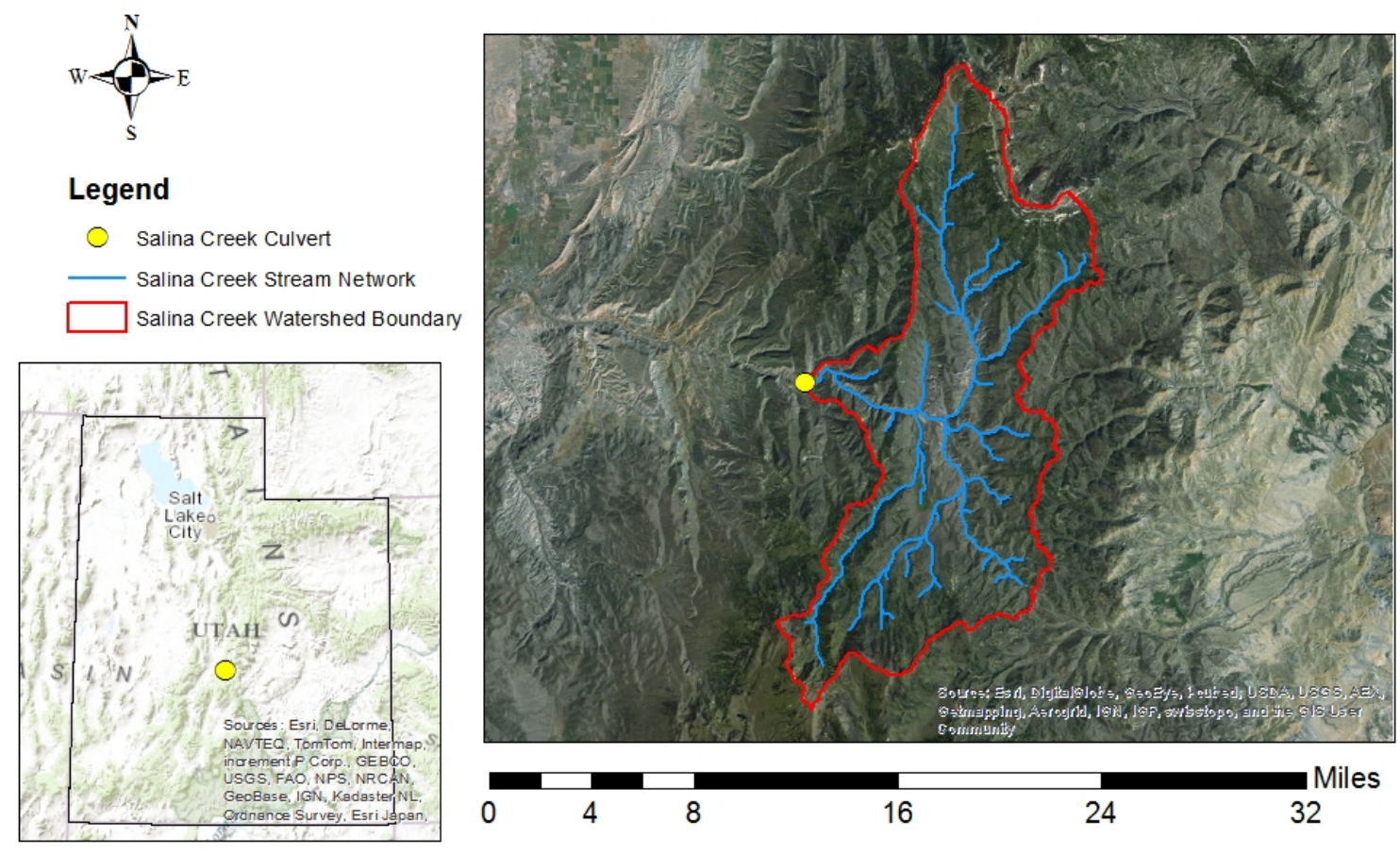

Figure 3-7: Salina Creek Watershed and Culvert Location.

\subsubsection{Salt Creek}

Salt Creek receives most of its drainage from Mount Nebo. The stream experiences high flows during snowmelt and exhibits steep slopes. In times of high discharge, average crosssectional velocities have exceeded 5 feet per second. The culvert is a large pipe-arch corrugated metal pipe. The culvert is off-set from the stream path; therefore, the stream direction is altered by the roadway embankment before entering the culvert. Figure 3-8 shows the Salt Creek culvert at the upstream invert, and Figure 3-9 depicts the Salt Creek watershed and culvert location. 


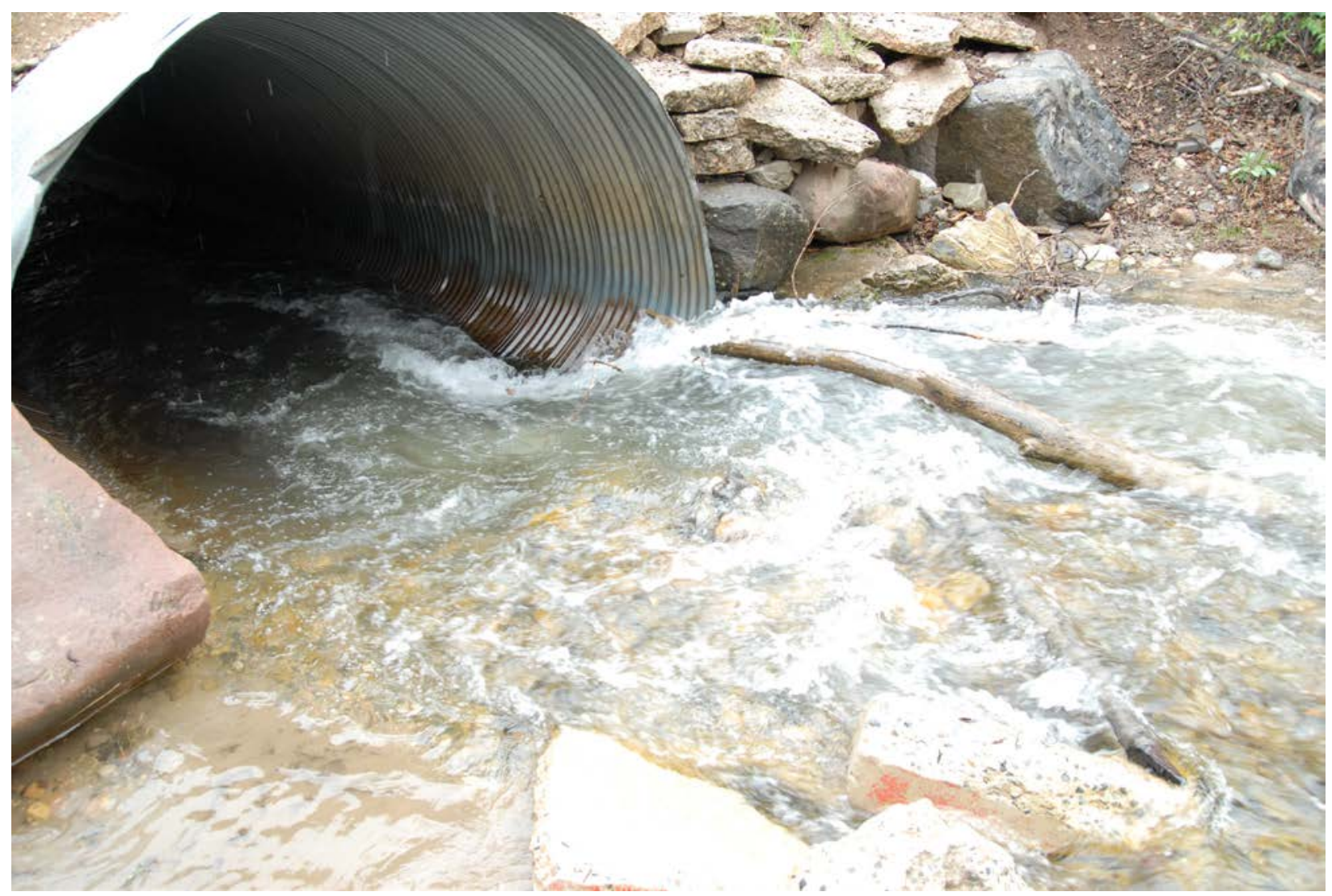

Figure 3-8: Salt Creek Culvert Upstream Invert. 

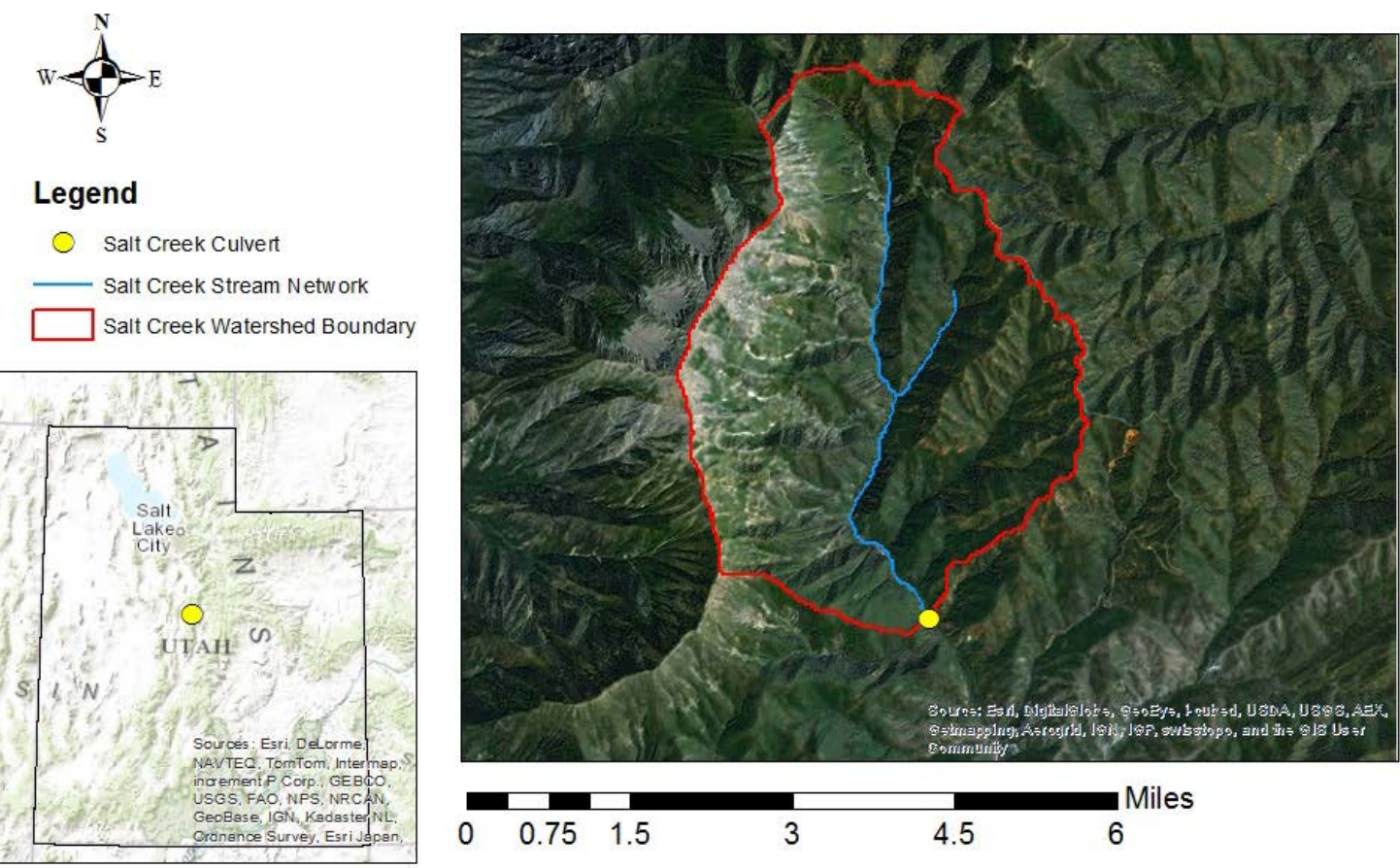

Figure 3-9: Salt Creek Watershed and Culvert Location.

\subsubsection{South Fork}

South Fork is a tributary to the Provo River and merges with the river at Vivian Park, Utah. At the point of the stream crossing, the river is flowing in an open valley. Some water is diverted for agricultural use upstream from the culvert site. The stream has an upstream watershed area of 28.1 square miles. The culvert is a circular corrugated metal pipe (Figure 3-10). The culvert is unique in that it was placed with an adverse slope. The culvert was found with greater depths of deposition upstream than downstream. The watershed and culvert location are mapped in Figure 3-11. 


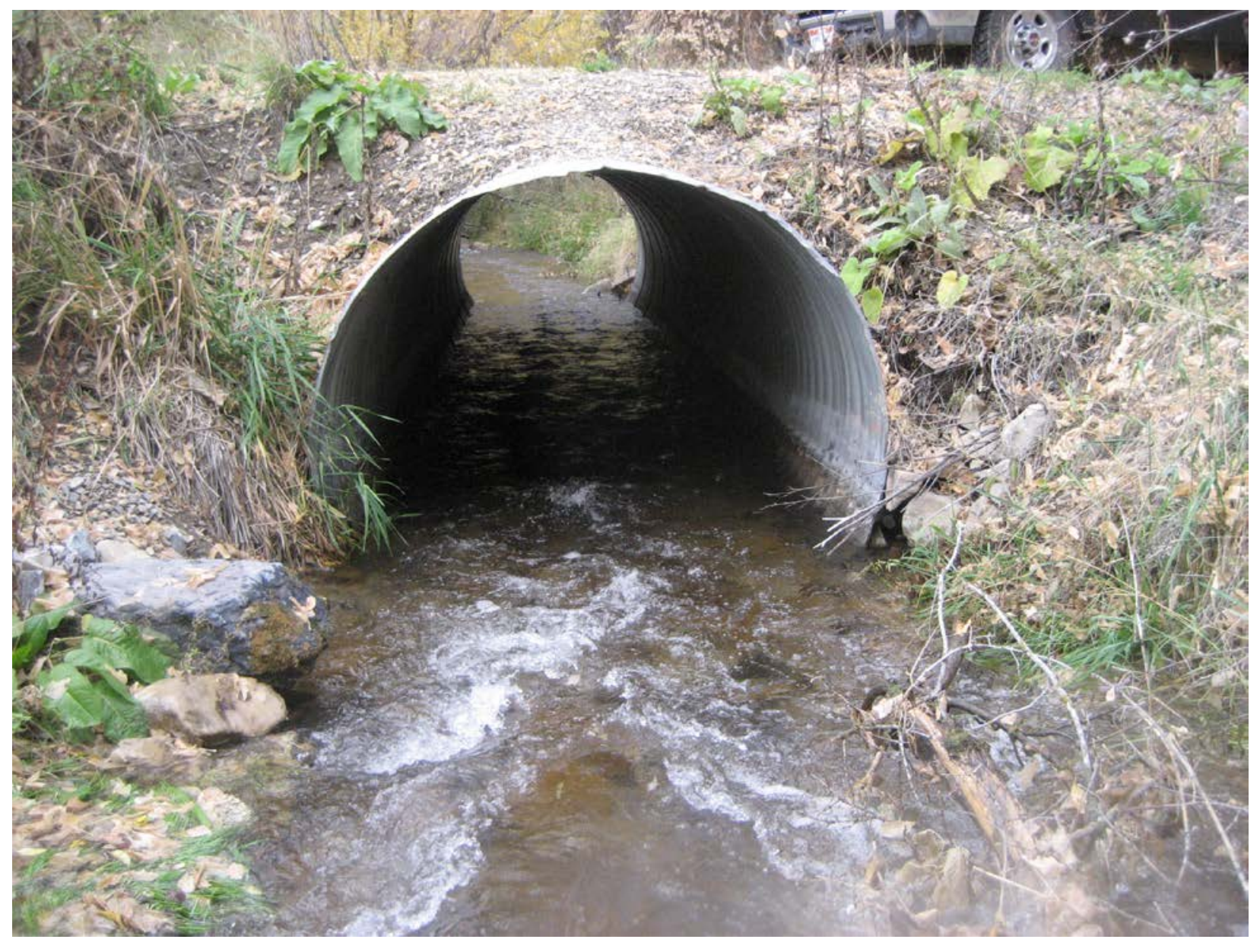

Figure 3-10: South Fork Culvert from Upstream Reach Looking Downstream. 


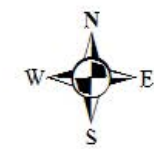

\section{Legend}

$\bigcirc$ South Fork Culvert
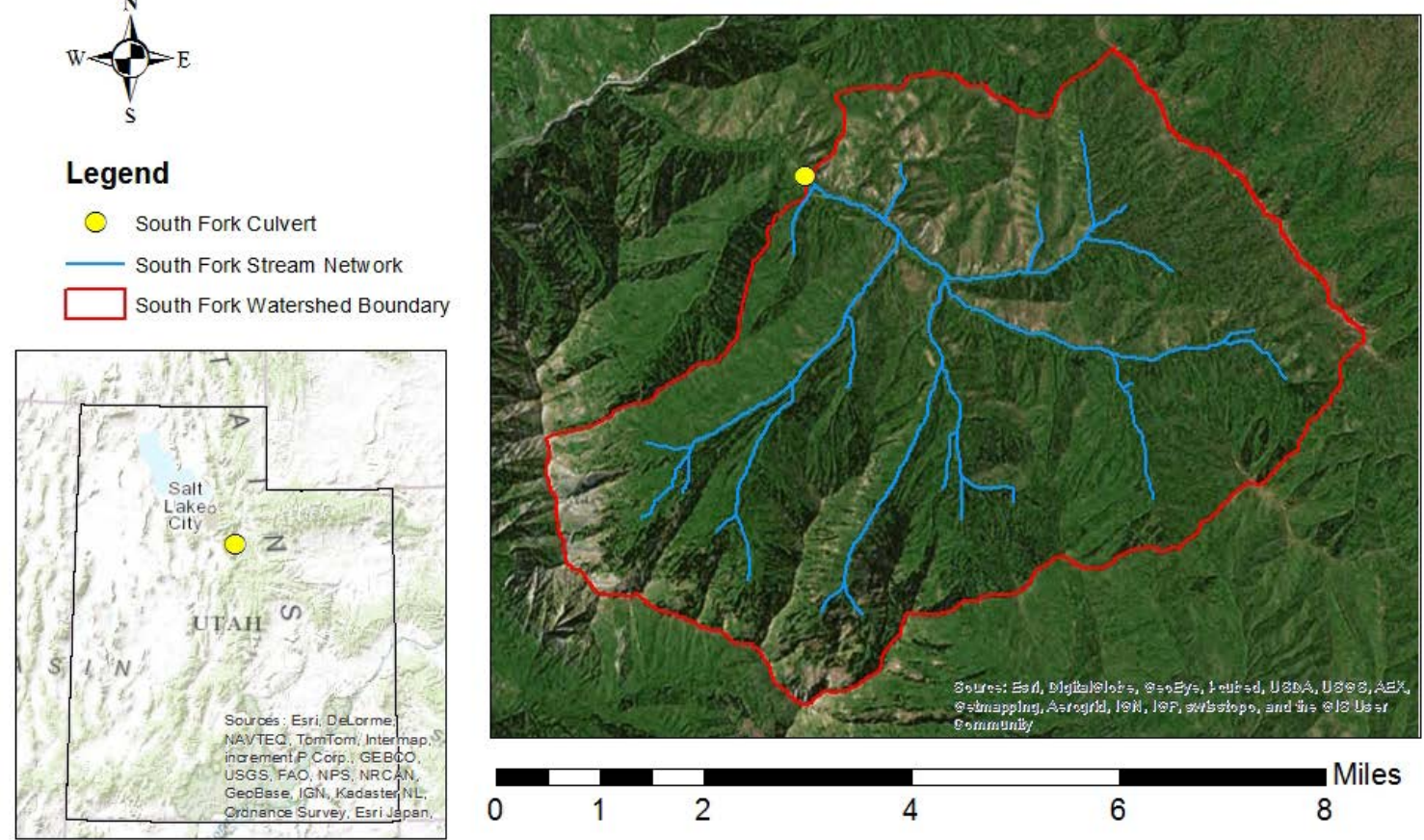

Figure 3-11: South Fork Watershed and Culvert Location.

\subsubsection{Summit Creek}

Summit Creek, near Santaquin, Utah, flows between steep, cliff-like canyon walls. The stream discharge is heavily influenced by snowmelt. The streambed is noted for a wide range of sediment sizes from very large boulders to small cobbles and gravels. The culvert was found with very large boulders in the upstream portion of the barrel with smaller sediments deposited in the lower portions of the culvert. The culvert is a pipe arch corrugated metal pipe as shown in Figure 3-12. A map of the Summit Creek watershed and culvert location is given in Figure 3-13. 


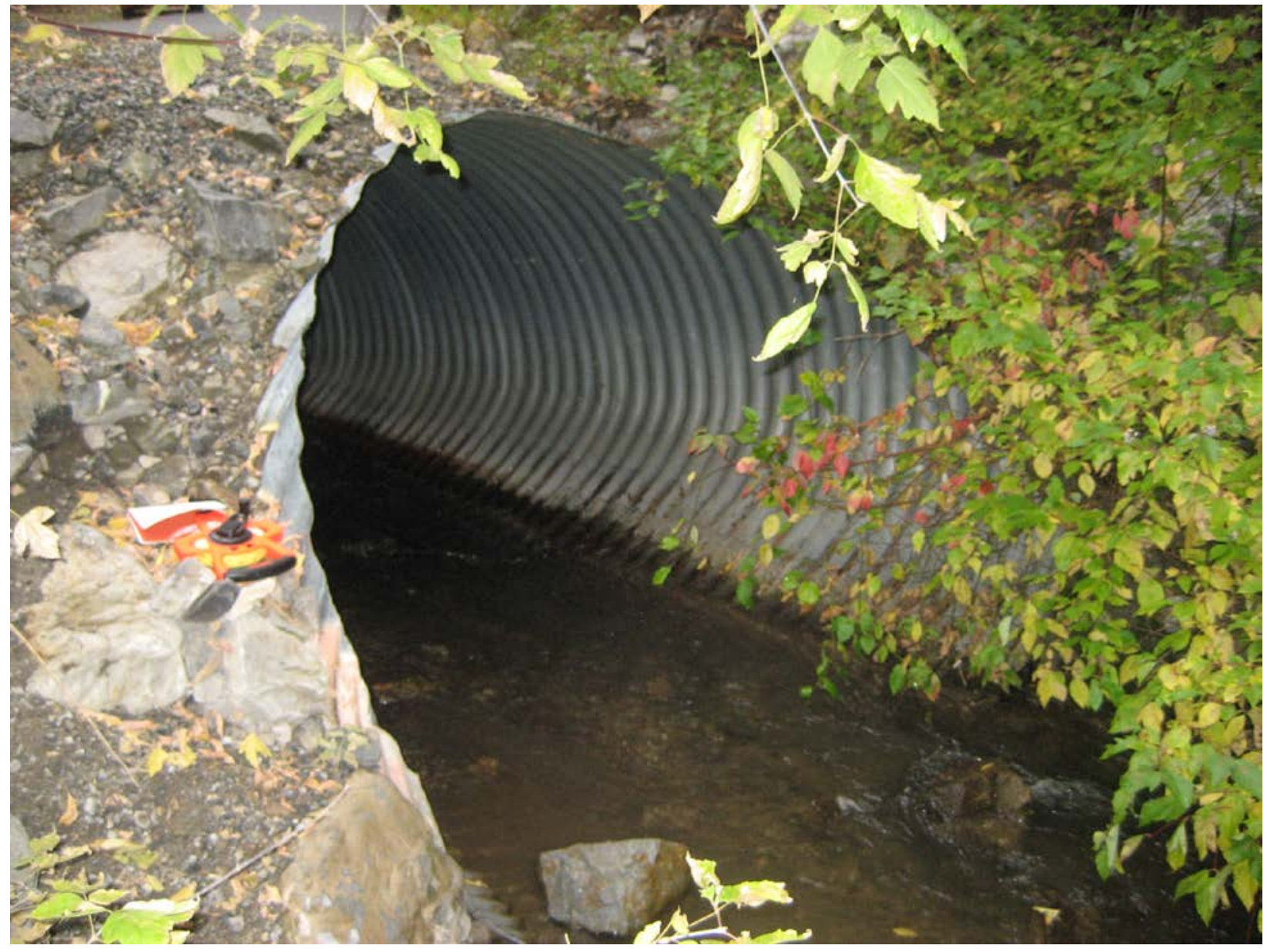

Figure 3-12: Summit Creek Culvert Downstream Invert. 

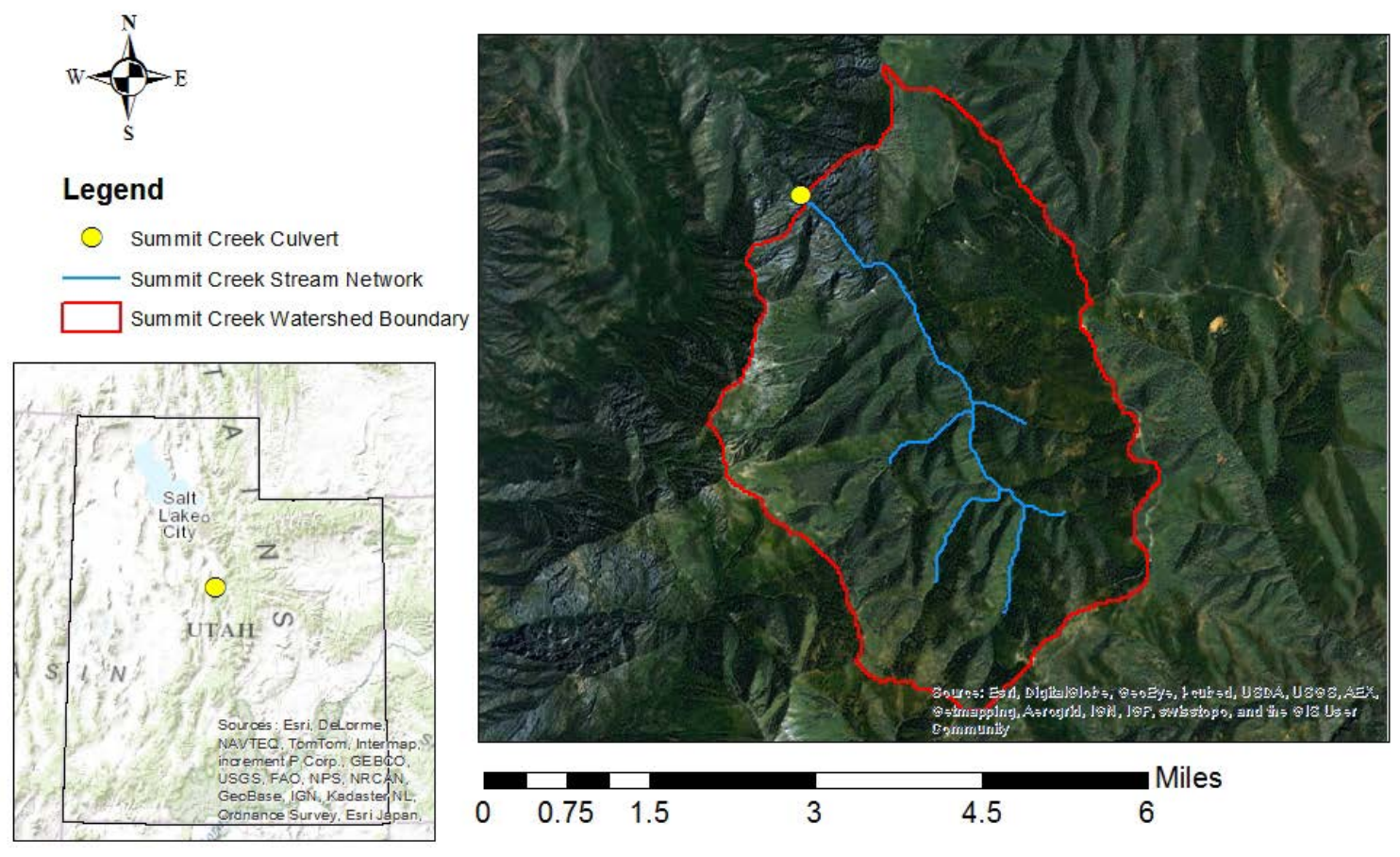

Figure 3-13: Summit Creek Watershed and Culvert Location. 


\subsection{Sediment Removal}

In theory, high erosive flows would remove embedment material from a culvert barrel. Sediment was removed from each culvert as a substitute for a high, erosive, and sediment removing flow (Figure 3-14). Each culvert would then act as a gage for sediment replenishment. The level of sediment replenishment could be measured from year to year. Sediment was removed from all of the culvert barrels except for Salina Creek, which was left unaltered for testing the numerical model for lateral fining capabilities. Permission to remove sediments from the culverts was obtained from Chuck Williamson of the Utah State Engineer's Office. Four of the five culverts that were cleared of sediment were owned and maintained by the U.S. Forest Service. Permission to work in USFS culverts was obtained from George Garcia, a district ranger.

Following the sediment removal work, each culvert was regularly monitored for changes in the sediment deposition and supply from early March of 2014 to late June of 2014. The monitoring process included field visits with each culvert physically inspected each time it was safe to enter. 


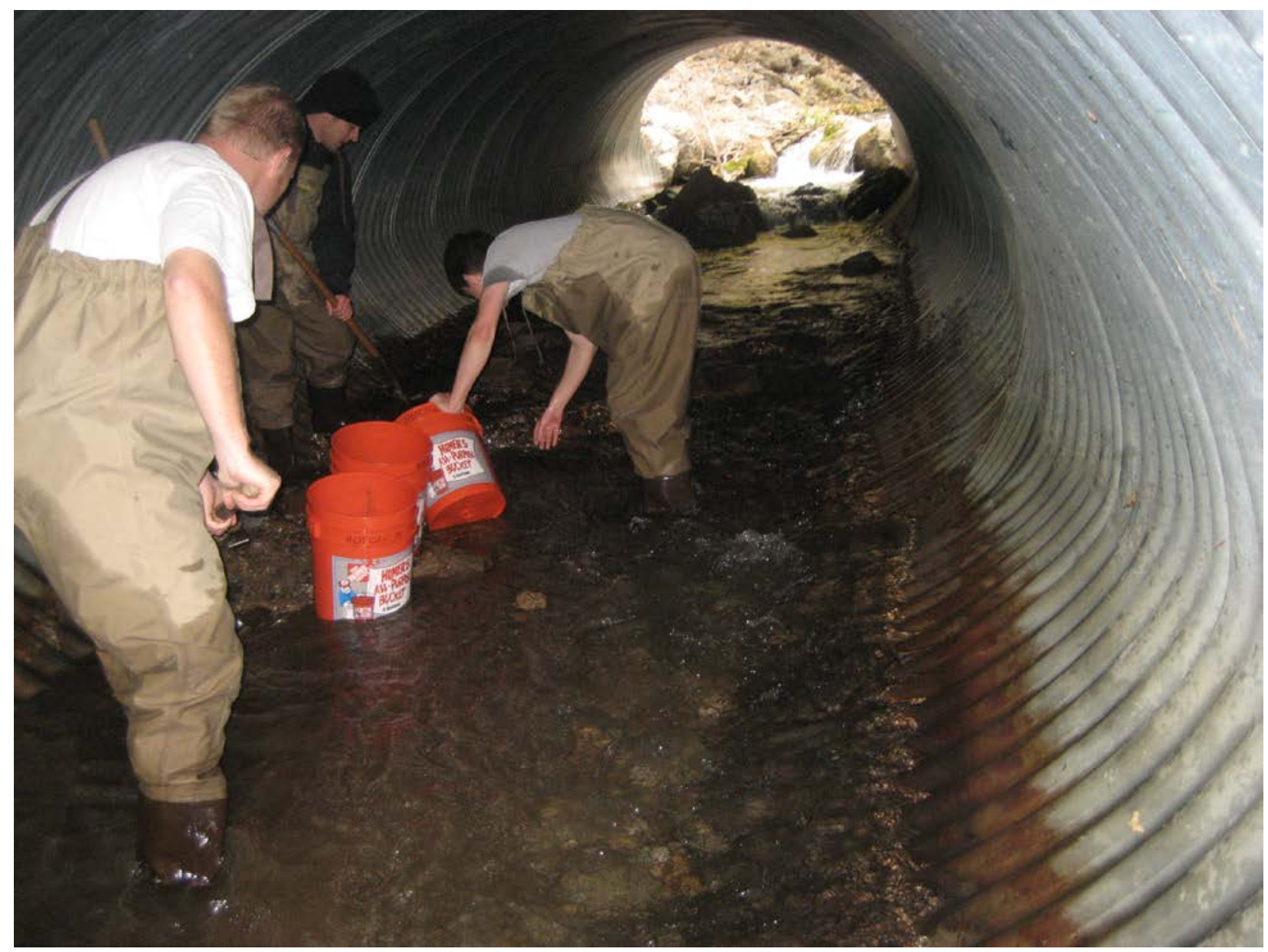

Figure 3-14: Ed Kern, Dan Jones, and Evan Cope Work to Remove Sediments from the Summit Creek Culvert Barrel.

\subsection{Discharge and Stage Measurement}

As the changes to sediment replenishment and deposition were regularly monitored, it was necessary to also compute the flow in an effort to understand the variables that were affecting the deposition and possess data from which to simulate and model the results. Flow measurements were taken with the Price AA and Pygmy current meters depending on the characteristics of the stream and the appropriate measurement method (Turnipseed 2010). Flow measurements were taken regularly through the spring runoff period to establish a rating curve for a standard CrestStage Gage and provide calibration data for a two-dimensional numerical model. Table 3-4 
compares the observed flows for the water year of 2014 with those computed from regression equations. Headwater to culvert rise ratios (HW/D) were calculated using HY-8 for each reported flow given in Table 3-4.

Table 3-4: Comparison of Maximum Observed Flow to Stream Regression Flows for Various Flood Return Periods (Kenney 2008).

\begin{tabular}{|c|c|c|c|c|c|c|c|c|}
\hline & $\begin{array}{c}\text { Maximum } \\
\text { Observed } \\
\text { Flow } \\
2014 \\
{\left[\mathrm{ft}^{3} / \mathrm{s}\right]} \\
\end{array}$ & $\begin{array}{c}2014 \\
\mathrm{HW} / \mathrm{D}\end{array}$ & $\begin{array}{c}\text { 2-year } \\
\text { Return } \\
\text { Period } \\
\text { Flow } \\
{\left[\mathrm{ft}^{3} / \mathrm{s}\right]}\end{array}$ & $\begin{array}{l}\text { 2-year } \\
\text { HW/D }\end{array}$ & $\begin{array}{c}\text { 5-year } \\
\text { Return } \\
\text { Period } \\
\text { Flow } \\
{\left[\mathrm{ft}^{3} / \mathrm{s}\right]}\end{array}$ & $\begin{array}{l}\text { 5-year } \\
\text { HW/D }\end{array}$ & $\begin{array}{c}25 \text {-year } \\
\text { Return } \\
\text { Period } \\
\text { Flow } \\
{\left[\mathrm{ft}^{3} / \mathrm{s}\right]}\end{array}$ & $\begin{array}{c}25- \\
\text { year } \\
\text { HW/D }\end{array}$ \\
\hline $\begin{array}{l}\text { Hall's } \\
\text { Fork }\end{array}$ & 8 & 0.12 & 12 & 0.15 & 30 & 0.27 & 70 & 0.47 \\
\hline $\begin{array}{l}\text { Red } \\
\text { Creek }\end{array}$ & $<1$ & 0.06 & 6 & 0.21 & 15 & 0.34 & 40 & 0.57 \\
\hline $\begin{array}{l}\text { Salina } \\
\text { Creek }\end{array}$ & no gage & -- & 340 & 0.35 & 600 & 0.51 & 1020 & 0.73 \\
\hline $\begin{array}{l}\text { Salt } \\
\text { Creek }\end{array}$ & 60 & 0.34 & 25 & 0.21 & 55 & 0.32 & 120 & 0.50 \\
\hline $\begin{array}{l}\text { South } \\
\text { Fork }\end{array}$ & 8 & 0.20 & 75 & 0.63 & 140 & 0.91 & 210 & 1.17 \\
\hline $\begin{array}{l}\text { Summit } \\
\text { Creek }\end{array}$ & 26 & 0.21 & 25 & 0.20 & 60 & 0.37 & 125 & 0.50 \\
\hline
\end{tabular}

\subsection{Sediment Sampling}

Since each culvert is placed in a unique drainage, each culvert is subject to unique conditions and environmental characteristics. One of the characteristics that was essential to understanding sediment transport conditions near culverts is the size and gradation of sediments within the barrel as well as upstream of the stream crossing. Additionally, to be able to effectively simulate sediment transport with a numerical model, sediment gradation data is 
required. This section will outline the methods used to sample sediment from the six culvert sites as well as how the data will be used to accomplish the purpose of the research.

For each location, pebble counts were completed to have a gradation of the surface sediments upstream from the culvert following criteria found in Bunte and Abt (2001). In addition to the upstream pebble count completed at each site, volumetric samples were taken in the barrel of the Salina Creek culvert to document the lateral fining occurring in the barrel.

The subsurface samples were brought to the Soils and Materials Labs at Brigham Young University. Using a coarse sieve for gravels and a fine sieve for sands, a particle-size distribution was determined following that standards outlined in ASTM D6913 - 04, Standard Test Methods for Particle-Size Distribution (Gradation) of Soils Using Sieve Analysis (ASTM 2009). The gradation was separated with a 3-inch, 2-inch, 1-inch, 0.75-inch, 0.5-inch, 0.375-inch, and a No. 4 for the coarse gradation. The fine gradation was separated with the No. 10, No. 20, No. 40, No. 100, and No. 200 sieve sizes. The weights were used to compute the percent passing for each sample taken from Salina Creek. The values were used to compare the lateral fining occurring in the culvert barrel spatially.

\subsection{Survey}

Topographical data was collected for each site to understand the slope and channel geometry for numerical modeling and analysis. For each site, survey points were taken several hundred feet upstream and downstream of each culvert. Points were taken using Global Positioning System (GPS) survey equipment as well as a Total Station. The survey data were used to create numerical models and gather information such as channel bed slope, culvert slope, and channel geometry. 


\subsection{Two-Dimensional Model}

For each research location, a two-dimensional mesh was created from the bathymetric data obtained from the survey. It was set up as a flexible mesh with a combination of triangles and quadrilaterals. The mesh is used as a data set or map to simulate or compute flow and sediment transport across each element. SRH-2D was used as the numerical solver. An example of a mesh is given in Figure 3-15.

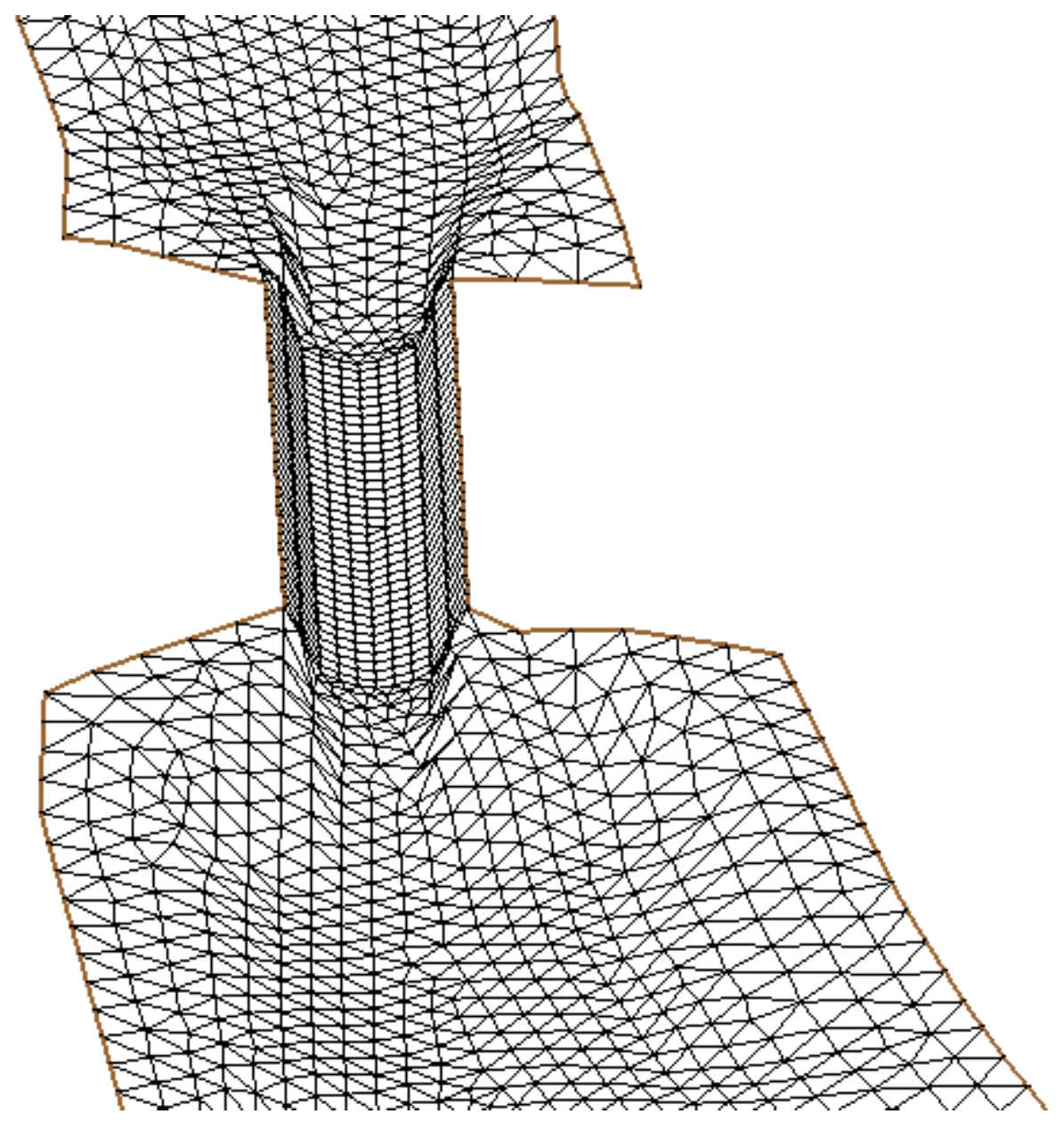

Figure 3-15: A Portion of the Mesh Used to Simulate the Hall's Fork Culvert. Flow Would Be from Bottom to Top. (Mesh Created using SMS v 11.1) 
Each element of the mesh has properties relating to a Manning's n roughness value, active layer sediment gradation, and subsurface sediment gradation and depths as input values. A list of additional inputs required by the model as a whole is given in Table 3-5. 
Table 3-5: SRH-2D Input Parameters

SRH Model Input

Run Type

Time Step

Duration

Turbulence module

Specific Gravity of Sediments

Number of Sediment Classes and sizes

Sediment Transport Equation

Water Temperature

Adaptation Coefficients

Adaptation Length

Active Layer Thickness

Boundary Conditions

\section{Description}

The run type specifies whether the model will include sediment transport computations.

The time step communicates how frequently to step through each iteration.

The length of the model runs in time.

The solution method to account for turbulence.

The specific gravity of the sediments in the active and subsurface layers.

An upper and lower sediment diameter is given for each size class. The user may include as many size classes as he or she feels necessary to capture the gradation.

A wide range of equations may be used to compute sediment transport across mesh elements along with equation coefficients.

The water temperature changes the density of the water and the buoyant forces acting on the sediment particles.

These values correspond to the deposition and erosion coefficients for suspended loads.

Values and equations are selected corresponding to bed load transport.

Values relating to the thickness of the active layer in terms of the D90.

Boundary conditions control what is going into the numerical mesh and what is coming out. Inlet and outlet conditions are specified here.

SRH-2D does not have the ability to simulate the full geometry of a culvert in twodimensions because it cannot simulate the top of the culvert. Therefore, the mesh was set up to simulate open channel flow through a culvert. It must be recognized that the model is unable to 
simulate pressure flow. However, the contraction modeled with the mesh mimicked the contraction associated with culvert hydraulics. Results obtained from the numerical model were used to compare with observations in the field at each of the culvert sites selected. The comparison showed the level of utility provided by SRH-2D for simulating sediment transport through culverts. 


\section{RESULTS AND DISCUSSION}

Separate results for the deposition of sediment at culvert entrances, sediment replenishment, and lateral fining are presented. Field observations and modeling results will be discussed for each of the three cases. Simulation results are given for hypothetical flooding conditions of return period flows of 2-, 5-, and 25-years. The observed field data were useful to understand what was happening in the field, but it should not be compared with the numerical flood models due to the low flow conditions observed across the state of Utah in 2014.

\subsection{Upstream Deposition}

From the culverts studied, it was determined that upstream deposition of coarse grained sediments is less common when culvert barrels are very large relative to the stream or slopes are so steep such that a backwater effect will not occur for any semi-consistent flood flow. However, upstream deposition has been noted to occur when a river reach is backwatered directly upstream from a culvert inlet. It is expected that deposition at the entrance is a function of increasing headwater elevations that are a function of the culvert geometry and discharge. 


\subsubsection{Field Observation}

Since streams are dynamic and constantly changing, depositional deltas are more difficult to visually see at any instance. Sediment deposition was observed at Salina Creek and Salt Creek while the other culvert sites did not show any deposition at the entrance.

\subsubsection{Salina Creek}

At Salina Creek, the deposition extends a short distance upstream of the contraction. While it is difficult to see the deposition visually, the deposition is evident (note: the deposition is outlined with a red line) when looking at the bathymetric data taken from a field survey (Figure 4-1). Before the flow splits between the two concrete box culverts, a depositional feature was observed upstream of the center wall.

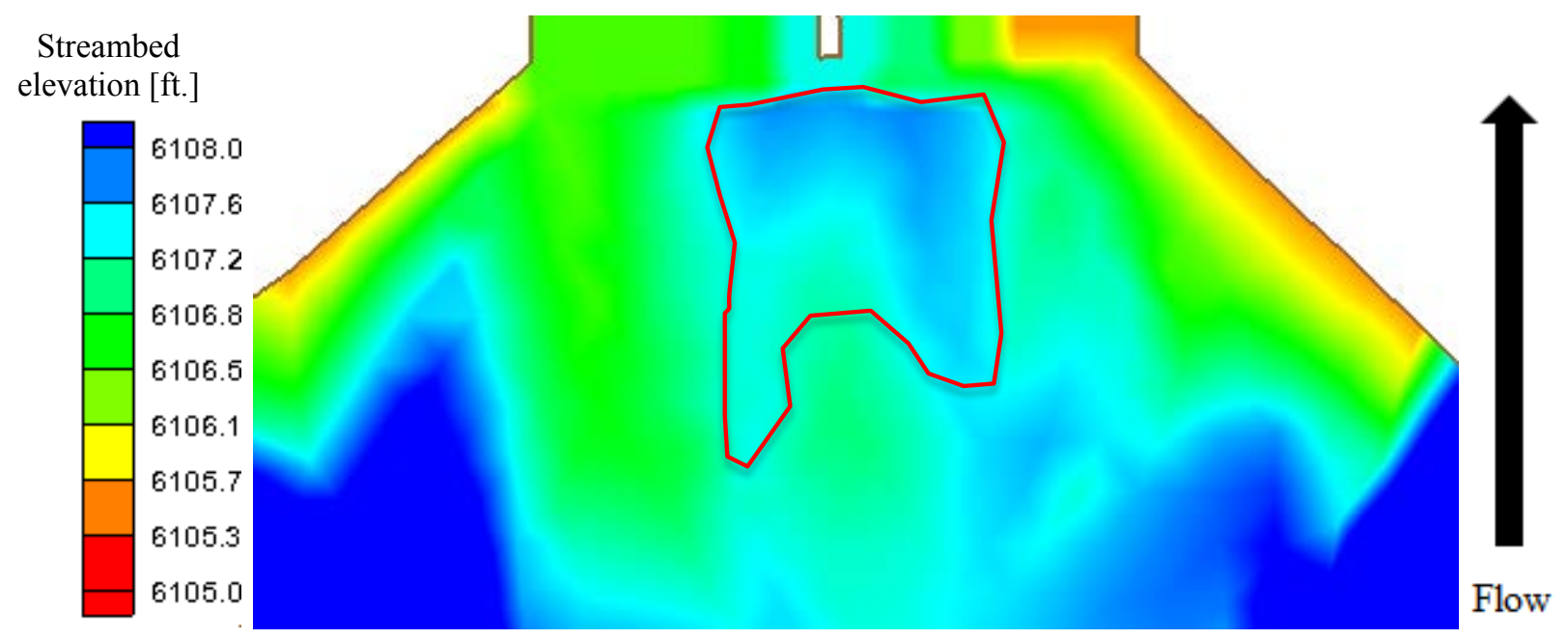

Figure 4-1: Topology of Upstream Deposition of Sediments.

\subsubsection{Salt Creek}

Sediment deposition dominates the right side of the streambed upstream of the Salt Creek culvert (Figure 4-2). The deposited substrate was easy to see when flows were low in the late fall of 2013. 


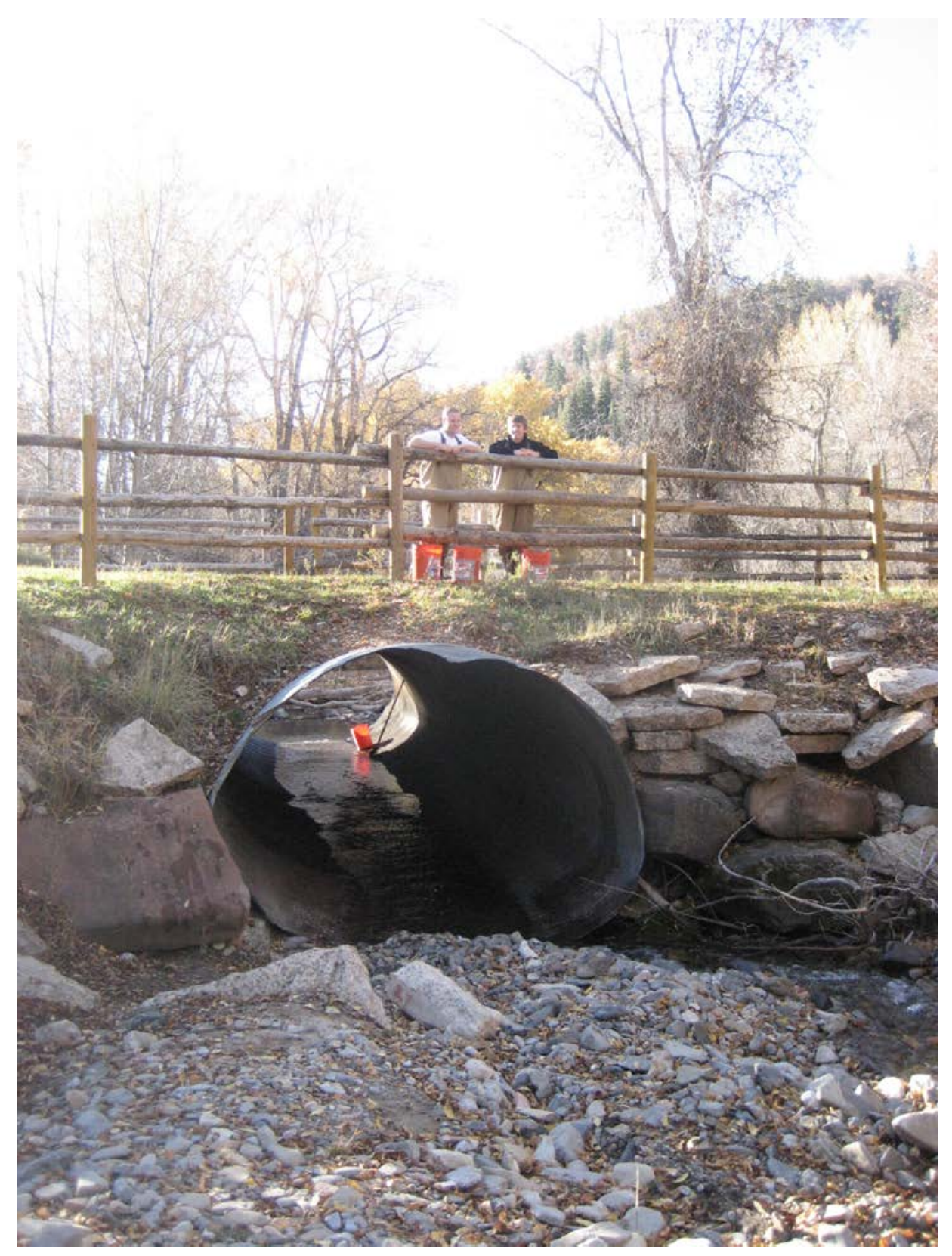

Figure 4-2: Deposition at the Salt Creek Culvert Entrance.

\subsubsection{Numerical Simulation}

Sediment deposition upstream of a culvert was reported with the numerical simulations of Hall's Fork, Salt Creek, and South Fork. The numerical simulation of Red Creek showed scour upstream of the stream crossing. The numerical simulation of Salina Creek did not show any change, whether scour or deposition, to the depositional delta that was measured in the field. 


\subsubsection{Hall's Fork}

The simulation of Hall's Fork shows the building of a small depositional delta for smaller flows; whereas, larger flows have greater depositional area and depth (Figure 4-3, Figure 4-4, and Figure 4-5).

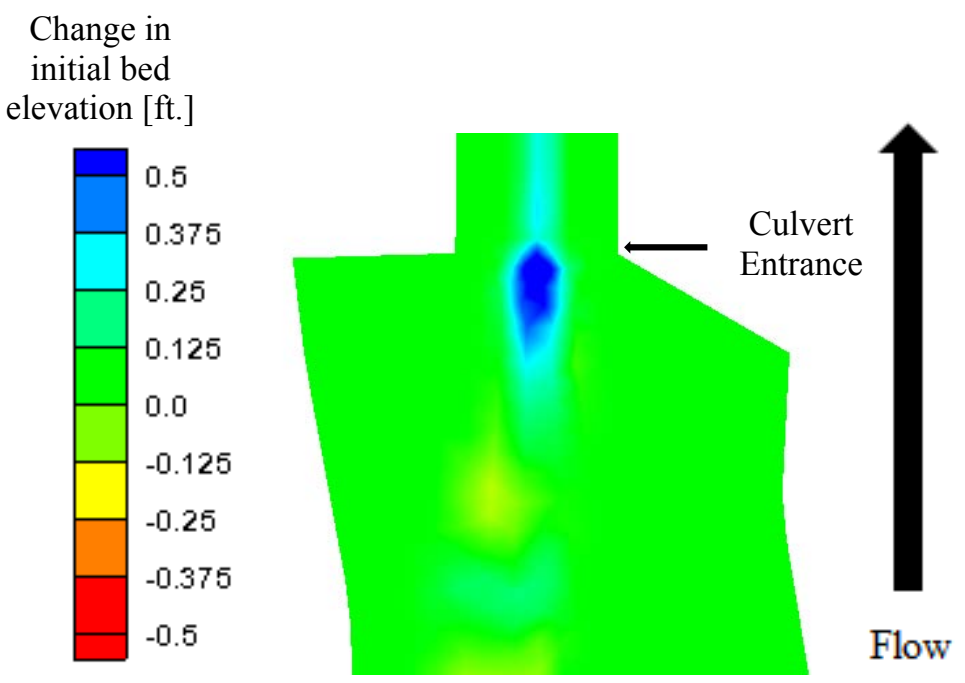

Figure 4-3: Simulation of Upstream Sediment Deposition for 2-year Flood.

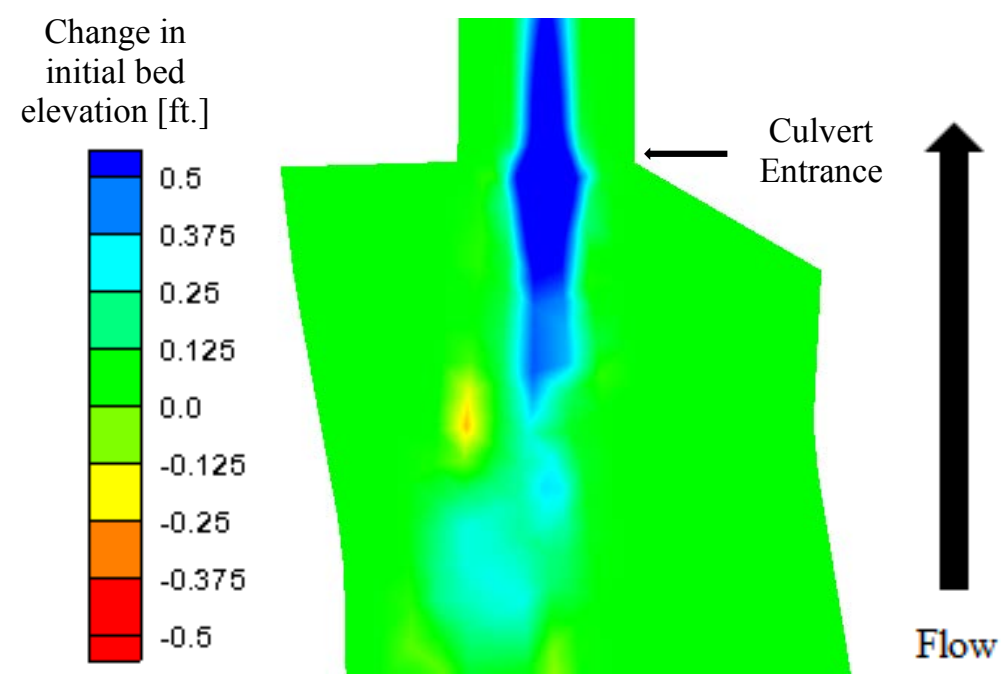

Figure 4-4: Simulation of Upstream Sediment Deposition for 5-year Flood 


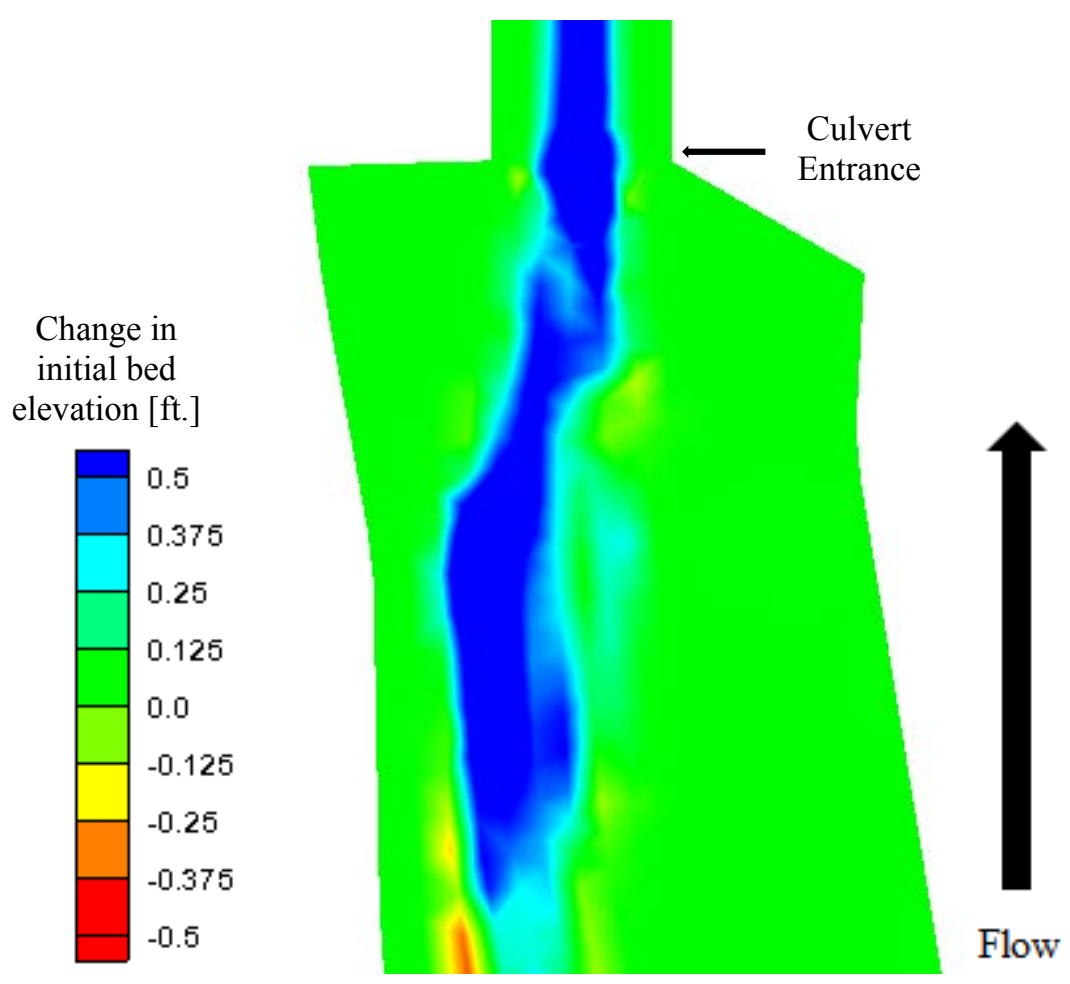

Figure 4-5: Simulation of Upstream Sediment Deposition for 25-year Flood.

\subsubsection{Salt Creek}

The Salt Creek Culvert site showed a small amount of deposition that extends into the culvert. The deposition is larger for greater flows and quite insignificant for smaller flows (Figure 4-6, Figure 4-7, and Figure 4-8). The figures also show small pockets of scour where the flow contracts. 


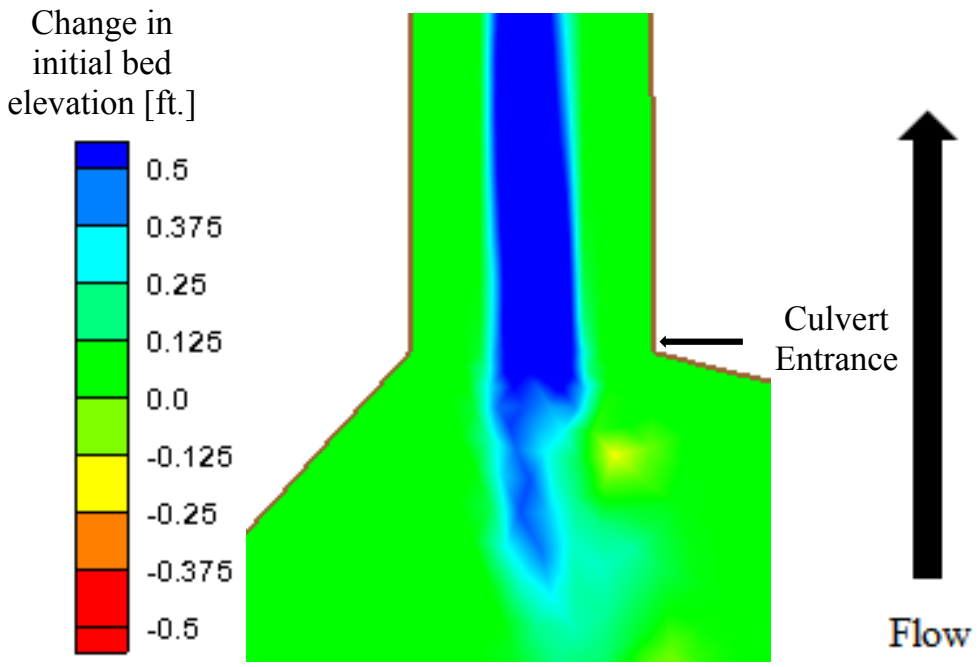

Figure 4-6: Simulation of Upstream Sediment Deposition for 2-year Flood.

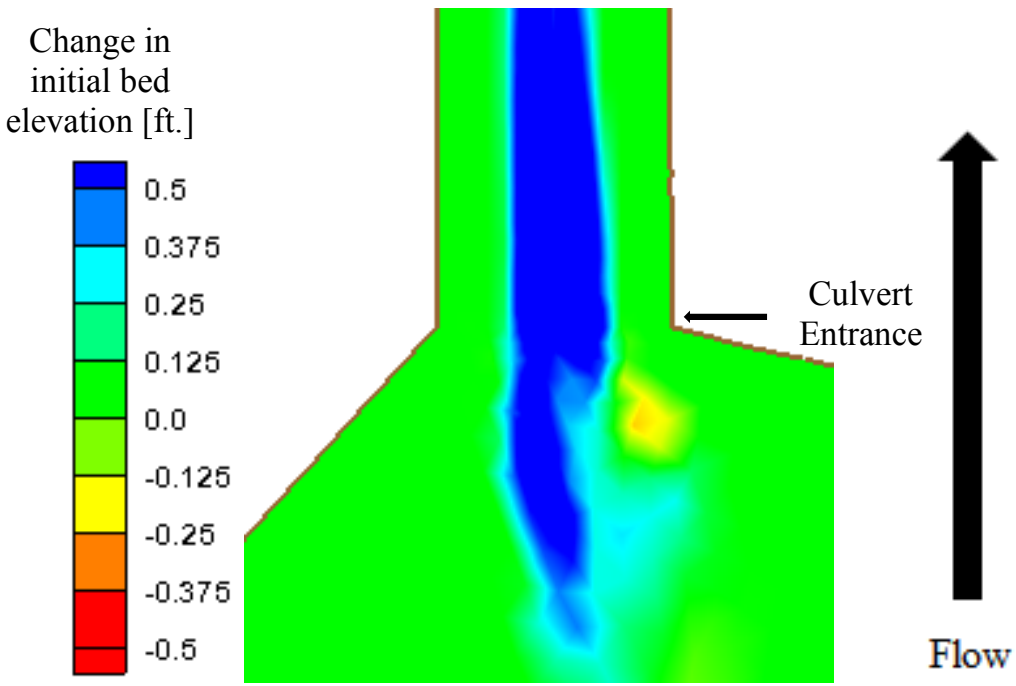

Figure 4-7: Simulation of Upstream Sediment Deposition for 5-year Flood. 


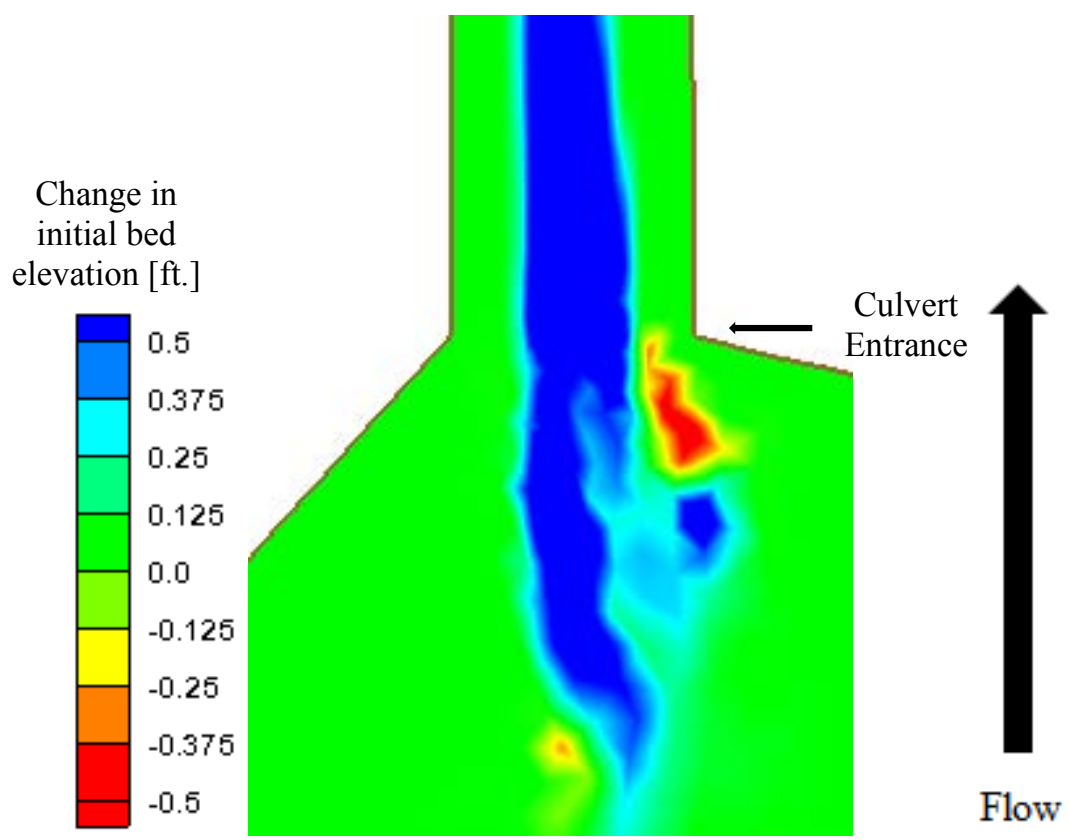

Figure 4-8: Simulation of Upstream Sediment Deposition for 25-year Flood.

\subsubsection{South Fork}

At the South Fork culvert site, the depositional structure builds with higher flows of sediment and water. As the deposition extends upstream, it also extends into the culvert itself (Figure 4-9, Figure 4-10, and Figure 4-11). 


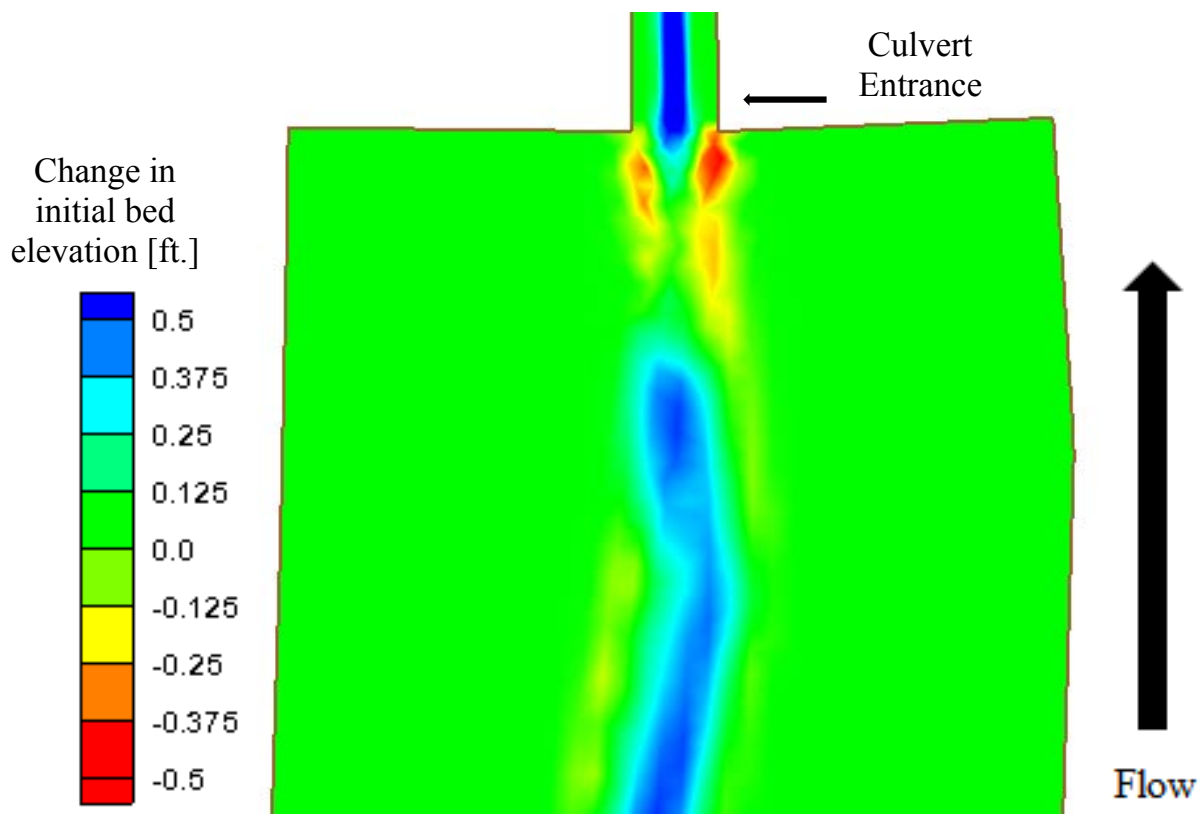

Figure 4-9: Simulation of Upstream Deposition for 2-year Flood.

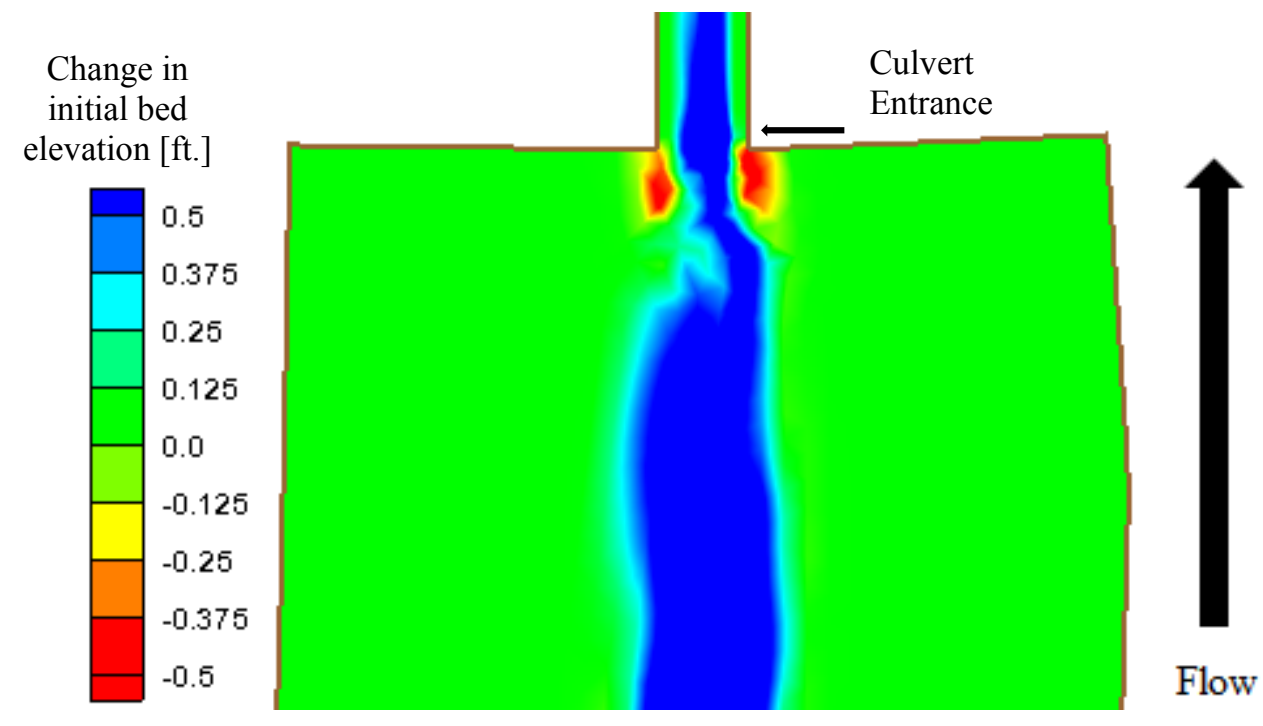

Figure 4-10: Simulation of Upstream Deposition for 5-year Flood. 


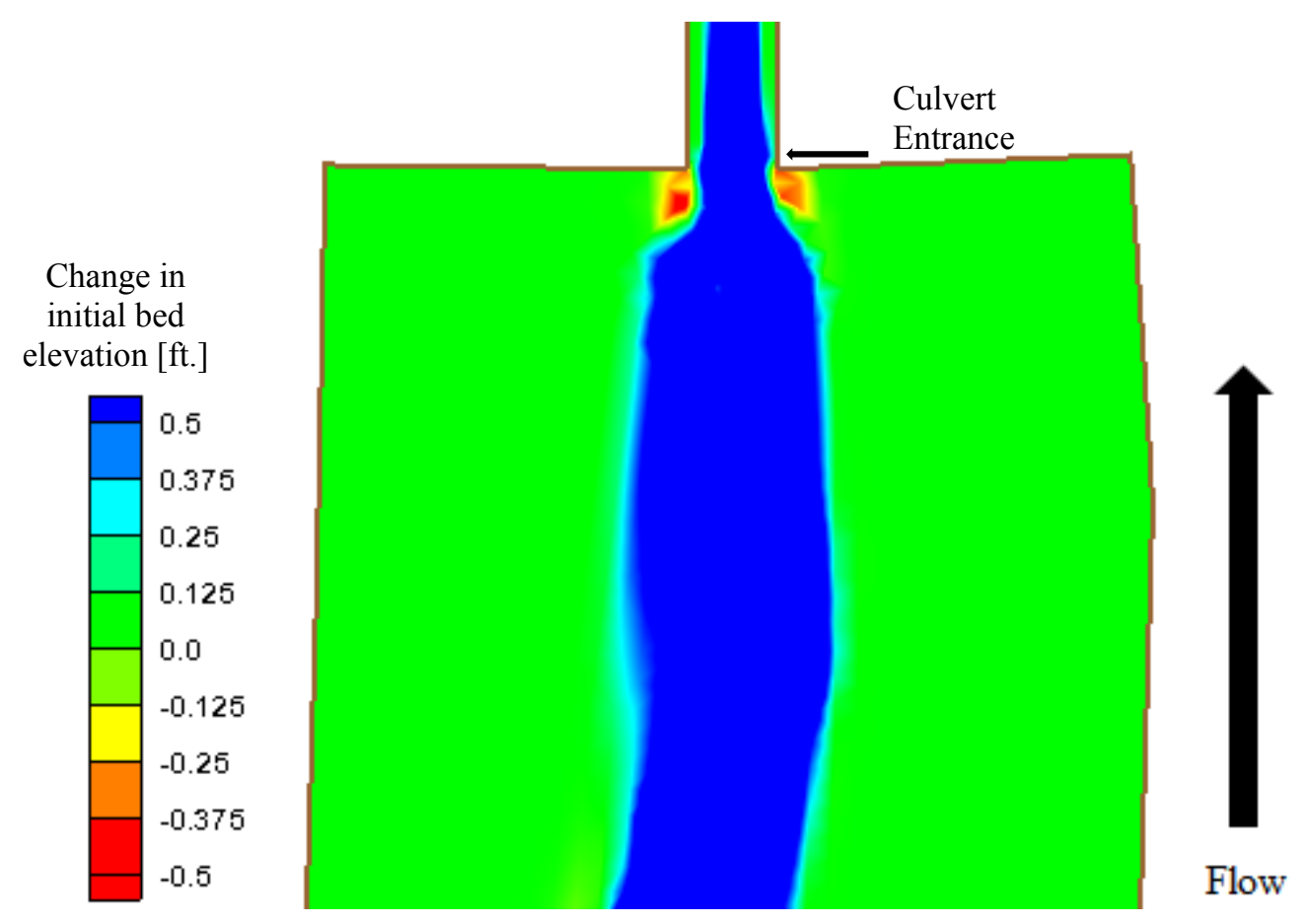

Figure 4-11: Simulation of Upstream Deposition for 25-year Flood.

Table 4-1 reviews the results observed in the field and simulated with the numerical model SRH-2D. The table shows that for Hall's Fork, Red Creek, South Fork, and Summit Creek, the current field observations do not apply to the resulting data. The observations to not apply due to the fact that the flows were significantly lower in the field than were used for the simulation. While deposition was observed in the field at the Salina Creek location, the simulation results are omitted because the bathymetric data used to set up the model included the deposition in its in-situ condition; therefore, it is unexpected that the model will show additional deposition. 
Table 4-1: Observation and Simulation Results Summary for Deposition of Sediments at a Culvert Entrance.

\begin{tabular}{lcc}
\hline & $\begin{array}{c}\text { Observed Deposition } \\
\text { at Culvert Entrance }\end{array}$ & $\begin{array}{c}\text { Simulated Deposition } \\
\text { at Culvert Entrance }\end{array}$ \\
\hline Hall's Fork & N/A & Y \\
Red Creek & N/A & N \\
Salina & Y & N/A \\
Creek & Y & Y \\
Salt Creek & N/A & Y \\
South Fork & N/A & no simulation \\
Summit & & \\
Creek & & \\
\hline
\end{tabular}

\subsection{Culvert Replenishment}

Five of the six culverts studied were selected based on the embedded condition of the culvert. The results will focus on numerical models created for Hall's Fork, Red Creek, Salt Creek, and South Fork. Field observations will be presented for Salt Creek and Summit Creek.

\subsubsection{Field Observations}

Measurements and observations from the field are valuable as a means of teaching and demonstrating the variables that influence the replenishment of substrate in the culvert barrel. During the 2014 spring runoff, insignificant substrate replenishment was observed at Hall's Fork, Red Creek, and South Fork. However, the culverts at Salt Creek and Summit Creek did show sediment deposition in the culvert.

\subsubsection{Salt Creek}

Sediment deposition in Salt Creek was quite uniform across the entire bed. The sediment reached a peak deposition at high flows. The falling limb of the spring hydrograph carried away 
some sediment leaving a smaller deposition. Sediments deposited in the Salt Creek culvert are shown in Figure 4-12 and Figure 4-13.

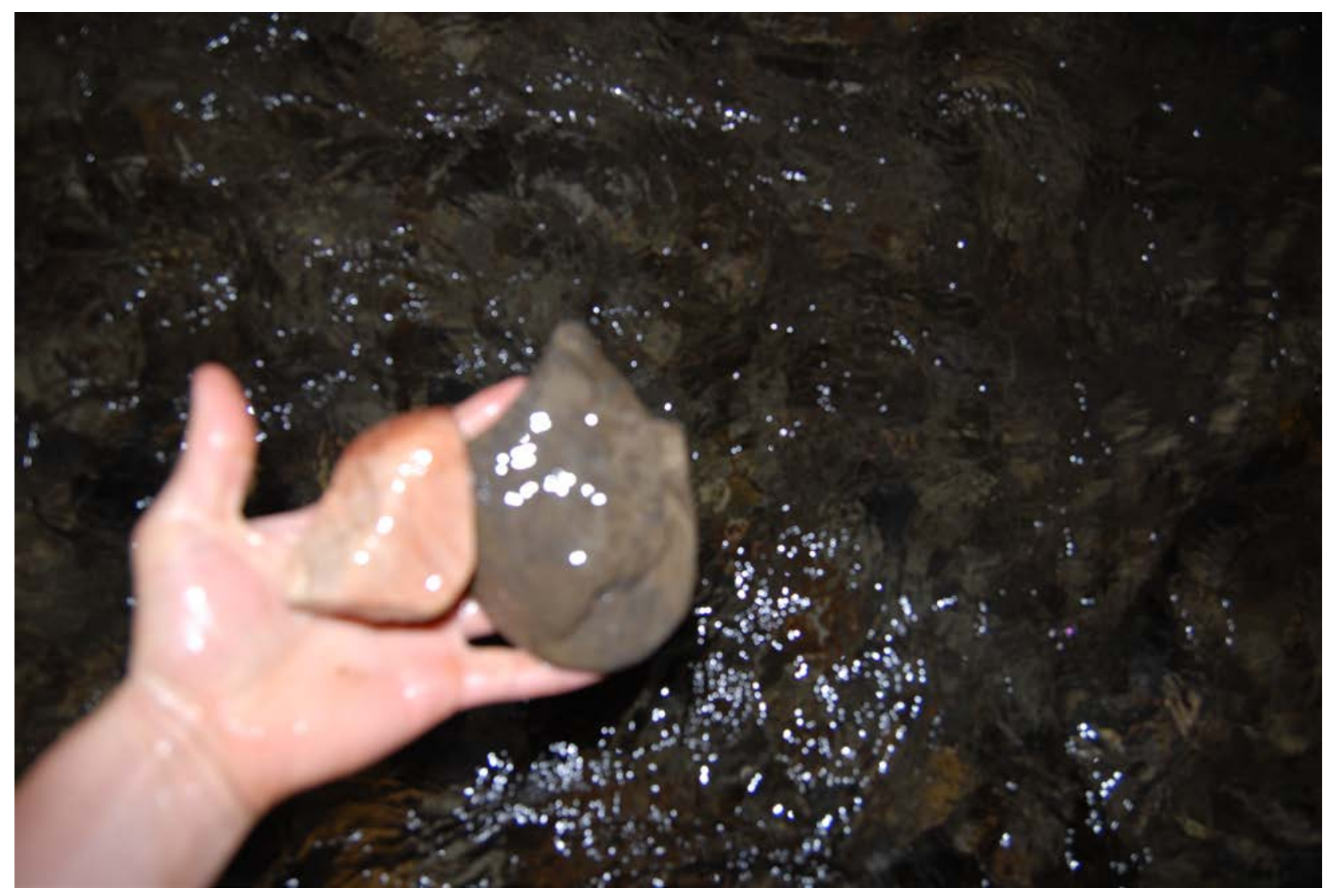

Figure 4-12: Sediment Deposits Found in Salt Creek Culvert Following High Flows. 


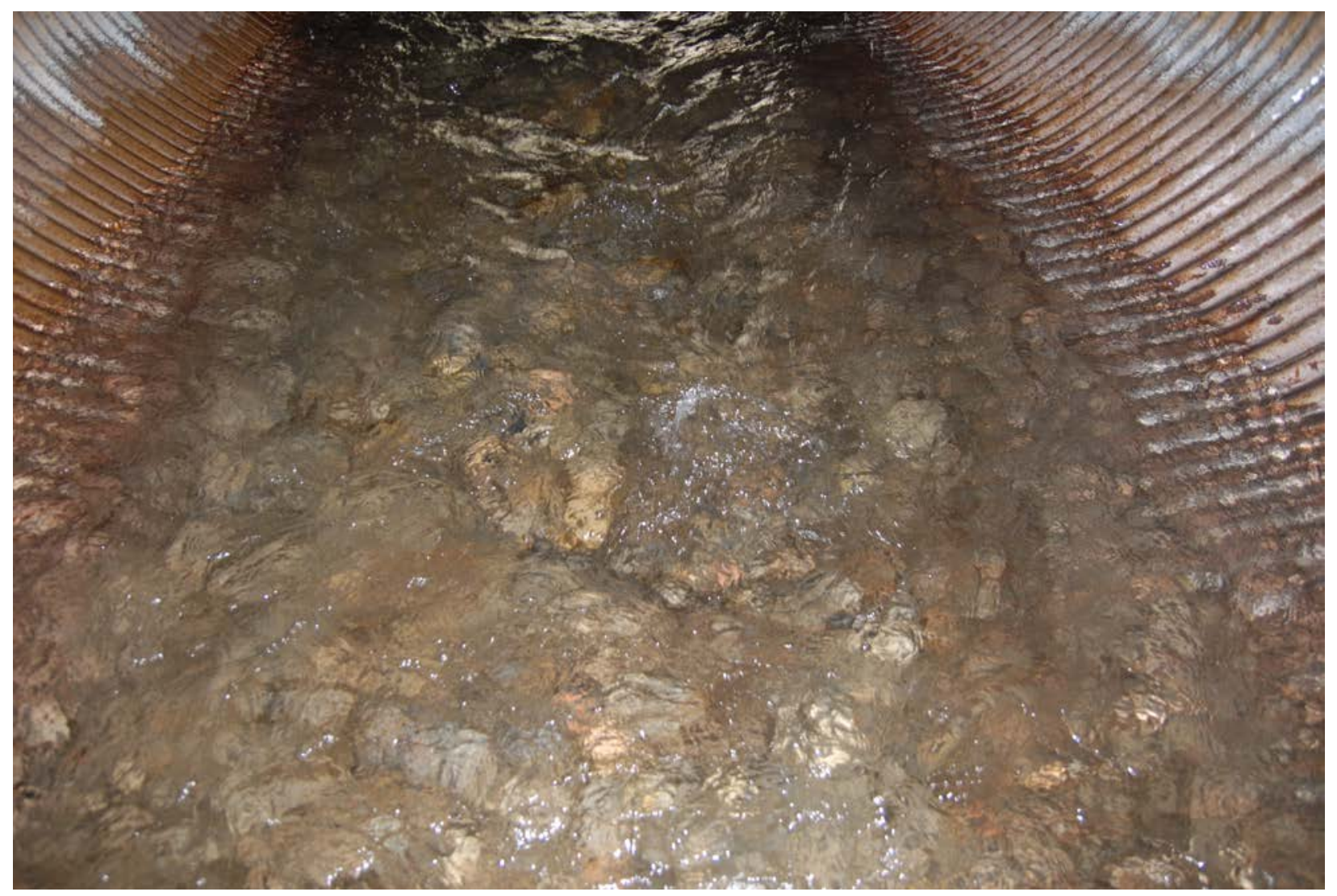

Figure 4-13: Sediments Deposited in the Salt Creek Culvert Barrel.

\subsubsection{Summit Creek}

The deposits in the Summit Creek culvert displayed a very non-uniform, poor gradation. A few small boulders had moved into the culvert barrel and smaller gravels were deposited behind the flow obstructions as shown in Figure 4-14 and Figure 4-15. 


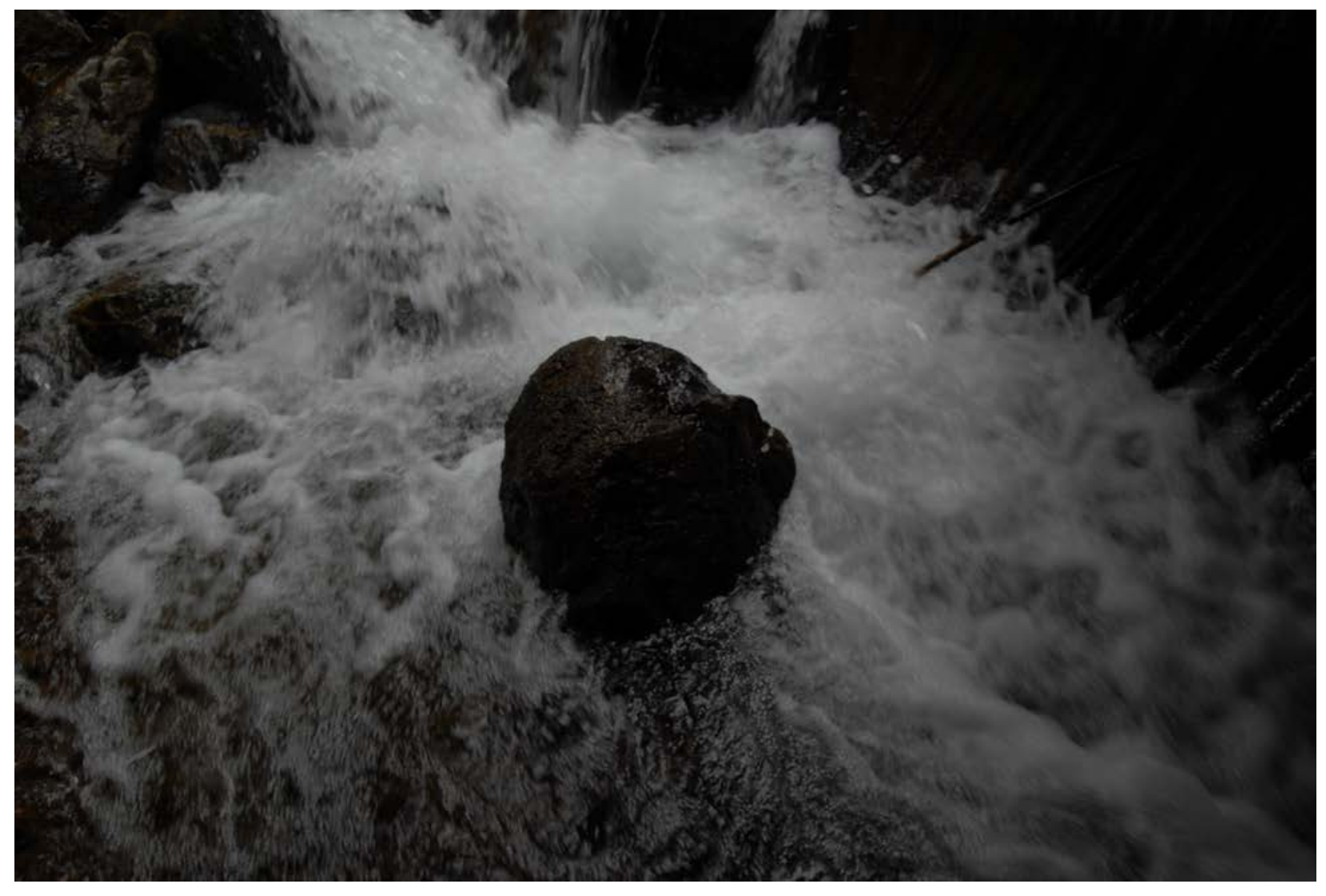

Figure 4-14: Small Boulder Settled inside the Summit Creek Culvert. 
Figure 4-15: Fine Sediments Hiding Behind Flow Obstruction.

\subsubsection{Numerical Models}

SRH-2D was used to simulate sediment replenishment to culverts where sediments have been removed from the barrel. The numerical results will report the maximum deposition replaced in the barrel following hypothetical flood flows of 2-, 5-, and 25-year return periods. Numerical results were also generated using the maximum observed flow for 2014. The value of the $\mathrm{D}_{50}$ will also be given for the point of maximum deposition.

\subsubsection{Hall's Fork}

For the Hall's Fork culvert, most of the deposition was reported by SRH-2D on the upstream end of the culvert which shows a good approximation with what was observed in the 
fall of 2013 before material was removed from the culvert barrel. The peak flow for 2014 was less than the two year flow.

Table 4-2: Maximum Sediment Deposition from SRH-2D Simulations for Hall's Fork.

\begin{tabular}{lcc}
\hline $\begin{array}{c}\text { Flood } \\
\text { Simulation }\end{array}$ & $\begin{array}{c}\text { Maximum Depositional Depth } \\
{[\mathrm{ft}]}\end{array}$ & $\begin{array}{c}\mathrm{D}_{50} \text { of Deposition } \\
{[\mathrm{mm}]}\end{array}$ \\
\hline 2-Year Flood & 0.27 & 10.2 \\
5-Year Flood & 0.82 & 13.5 \\
25-Year Flood & 1.1 & 28.7 \\
2014 Peak Flow & 0.23 & 7.1 \\
\hline
\end{tabular}

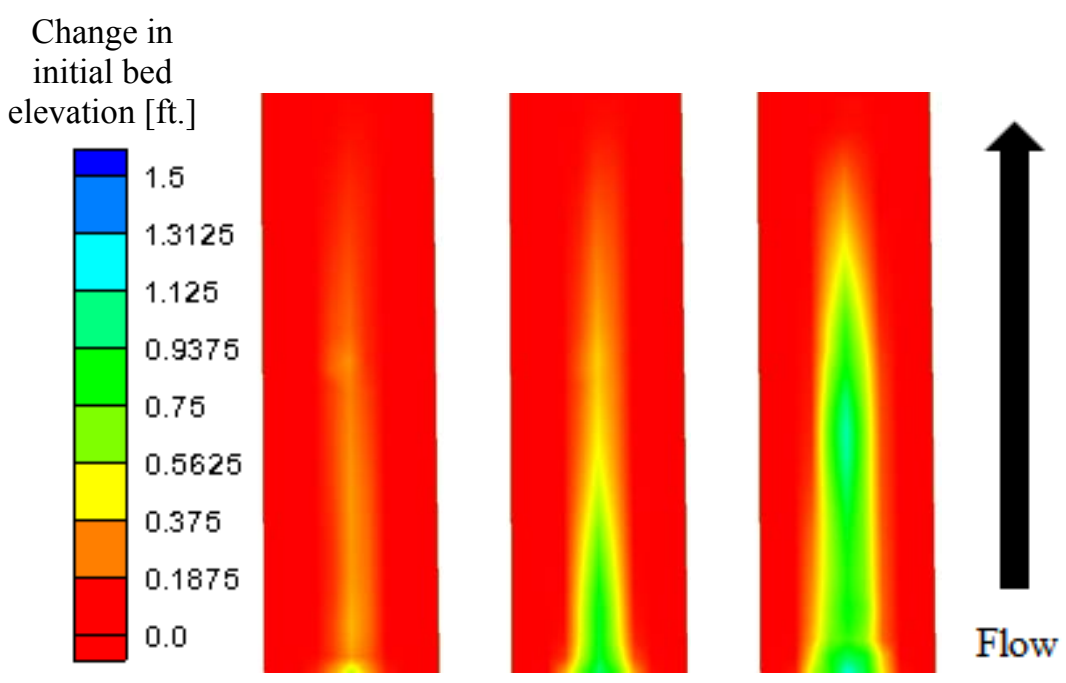

Figure 4-16: Sediment Depositional Depths for the 2-, 5-, and 25- year Floods in Feet from Simulations. 


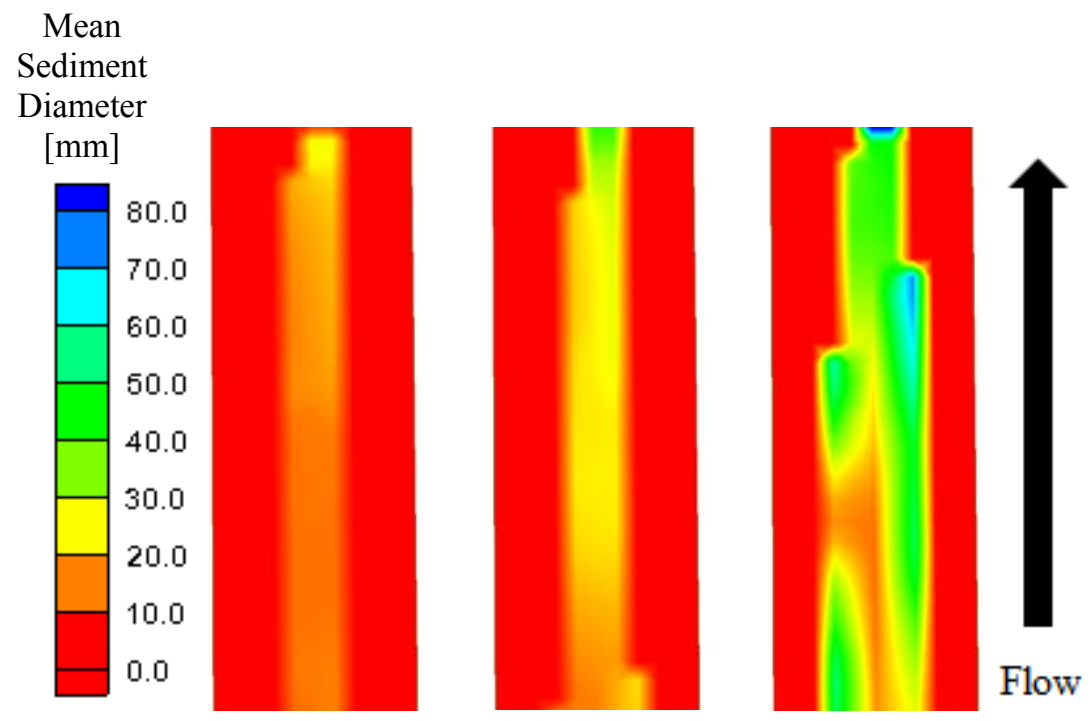

Figure 4-17: Mean Sediment Diameter for 2-, 5-, and 25-year Floods in Millimeters from Simulations.

\subsubsection{Red Creek}

The steep culvert on Red Creek showed deposition near the outlet for the 25-year flood as was observed in the fall of 2013 before material was removed from the culvert barrel. However, no deposition was reported for lower flows. The maximum observed flows from the 2014 spring runoff were less than the 2-year hypothetical flow.

Table 4-3: Maximum Sediment Deposition from SRH-2D Simulations for Red Creek.

\begin{tabular}{ccc}
\hline $\begin{array}{c}\text { Flood } \\
\text { Simulation }\end{array}$ & $\begin{array}{c}\text { Maximum Depositional Depth } \\
{[\mathrm{ft}]}\end{array}$ & $\begin{array}{c}\mathrm{D}_{50} \text { of Deposition } \\
{[\mathrm{mm}]}\end{array}$ \\
\hline 2-Year Flood & 0 & $\mathrm{n} / \mathrm{a}$ \\
5-Year Flood & 0 & $\mathrm{n} / \mathrm{a}$ \\
25-Year Flood & 0.88 & 98.6 \\
2014 Peak Flow & 0 & $\mathrm{n} / \mathrm{a}$ \\
\hline
\end{tabular}




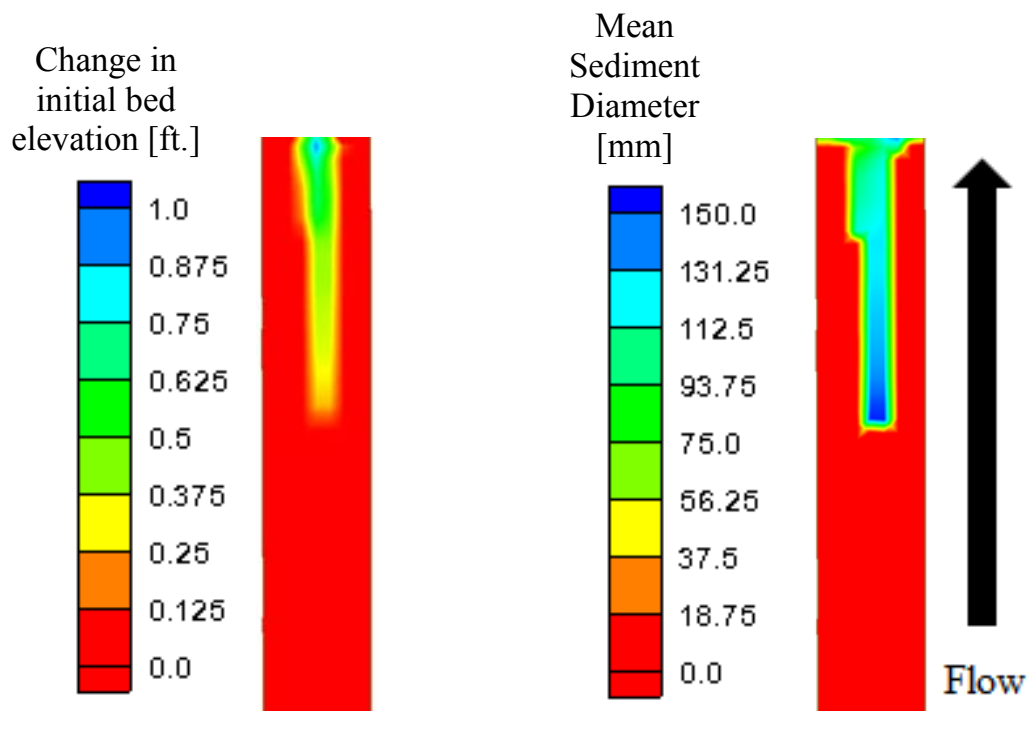

Figure 4-18: Deposition (left) in Feet and Mean Sediment Size in Millimeters (right) for the Red Creek Culvert with 25-year Flood Conditions from Simulations.

\subsubsection{Salt Creek}

The numerical results for Salt Creek showed deposition throughout the barrel. Such deposition fits well with field observations. Although the depth increased with greater discharges, the median sediment size changed very little. The maximum observed flow for 2014 was very similar to the 2-year hypothetical flow.

Table 4-4: Maximum Sediment Deposition from SRH-2D Simulations for Salt Creek.

\begin{tabular}{lcc}
\hline $\begin{array}{c}\text { Flood } \\
\text { Simulation }\end{array}$ & $\begin{array}{c}\text { Maximum Depositional Depth } \\
{[\mathrm{ft}]}\end{array}$ & $\begin{array}{c}\mathrm{D}_{50} \text { of Deposition } \\
{[\mathrm{mm}]}\end{array}$ \\
\hline 2-Year Flood & 0.6 & 5.7 \\
5-Year Flood & 1.0 & 6.0 \\
25-Year Flood & 1.3 & 6.8 \\
2014 Peak Flow & 0.5 & 5.3 \\
\hline
\end{tabular}




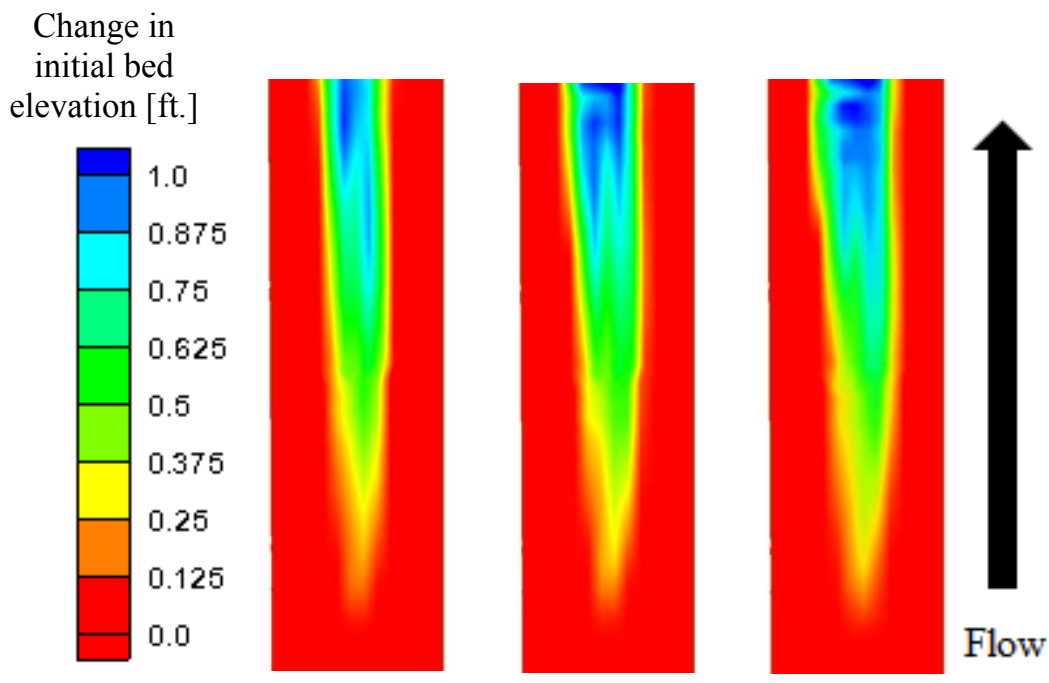

Figure 4-19: Sediment Depositional Depth for the 2-, 5-, and 25-year Floods Given in Feet from Simulations.

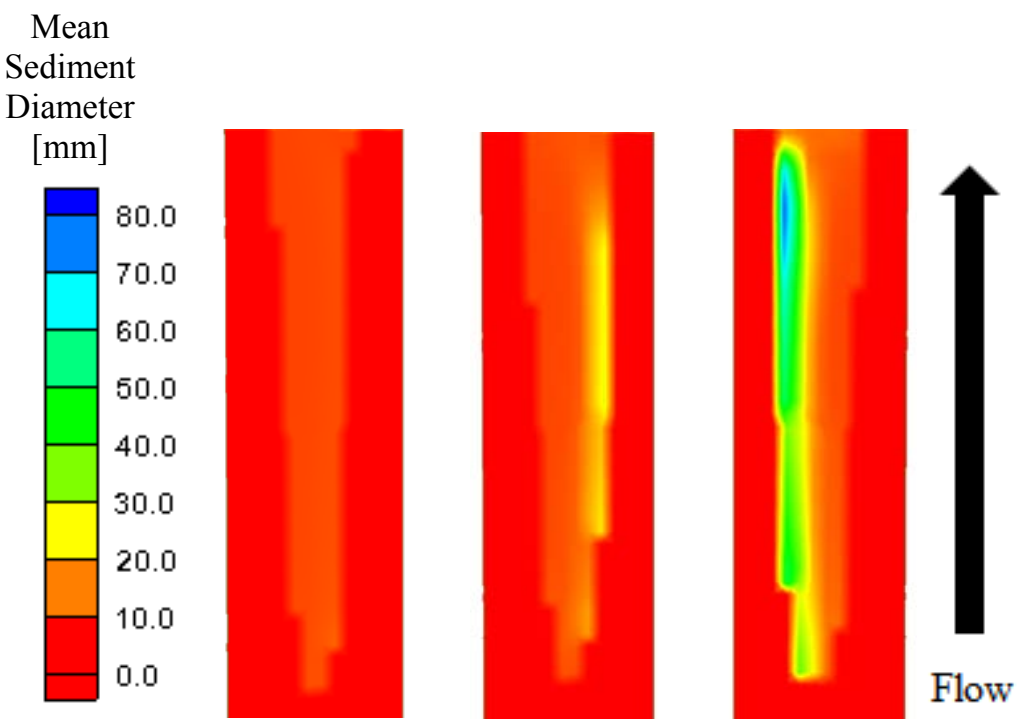

Figure 4-20: Mean Sediment Diameter in Millimeters for the 2-, 5-, and 25-year Floods from Simulations. 


\subsubsection{South Fork}

The simulation showed greater depths of deposition on the upstream side of the culvert with the depositional depth decreasing longitudinally. The results correlated well with field observations before the substrate in the barrel was removed. The simulation reported that depths increased as well and the median sediment size with greater flows. The maximum flows recorded for 2014 were much less than the hypothetical 2-year return period flow.

Table 4-5: Maximum Sediment Deposition from SRH-2D Simulations for South Fork.

\begin{tabular}{lcc}
\hline $\begin{array}{c}\text { Flood } \\
\text { Simulation }\end{array}$ & $\begin{array}{c}\text { Maximum Depositional Depth } \\
{[\mathrm{ft}]}\end{array}$ & $\begin{array}{c}\mathrm{D}_{50} \text { of Deposition } \\
{[\mathrm{mm}]}\end{array}$ \\
\hline 2-Year Flood & 0.7 & 14.3 \\
5-Year Flood & 1.3 & 46.1 \\
25-Year Flood & 1.8 & 63.1 \\
2014 Peak Flow & 0.2 & 2.8 \\
\hline
\end{tabular}

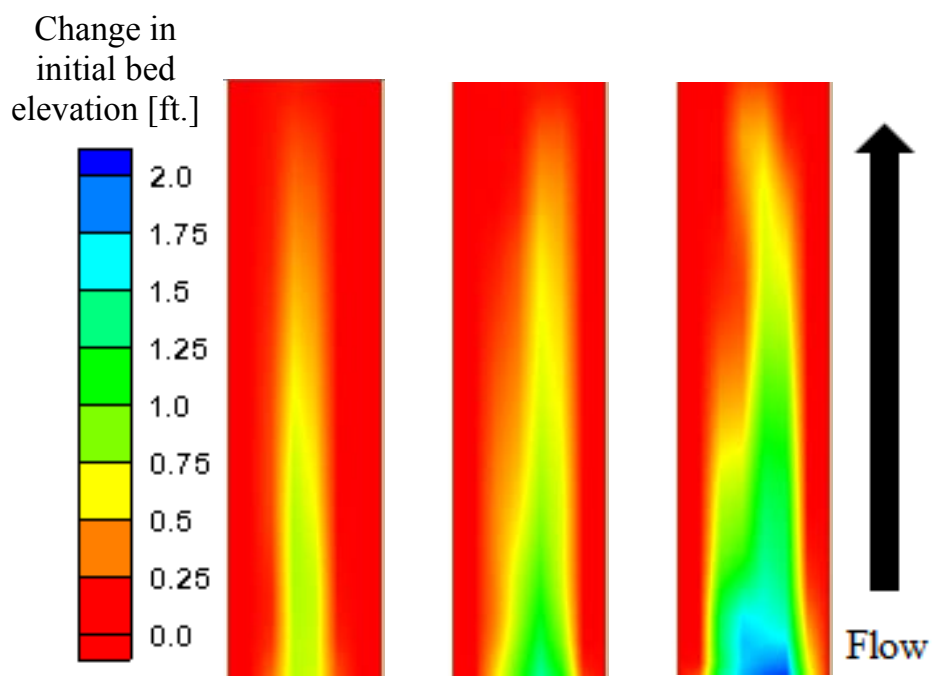

Figure 4-21: Sediment Depositional Depth in Feet for the 2-, 5-, and 25-year Flood from Simulations. 


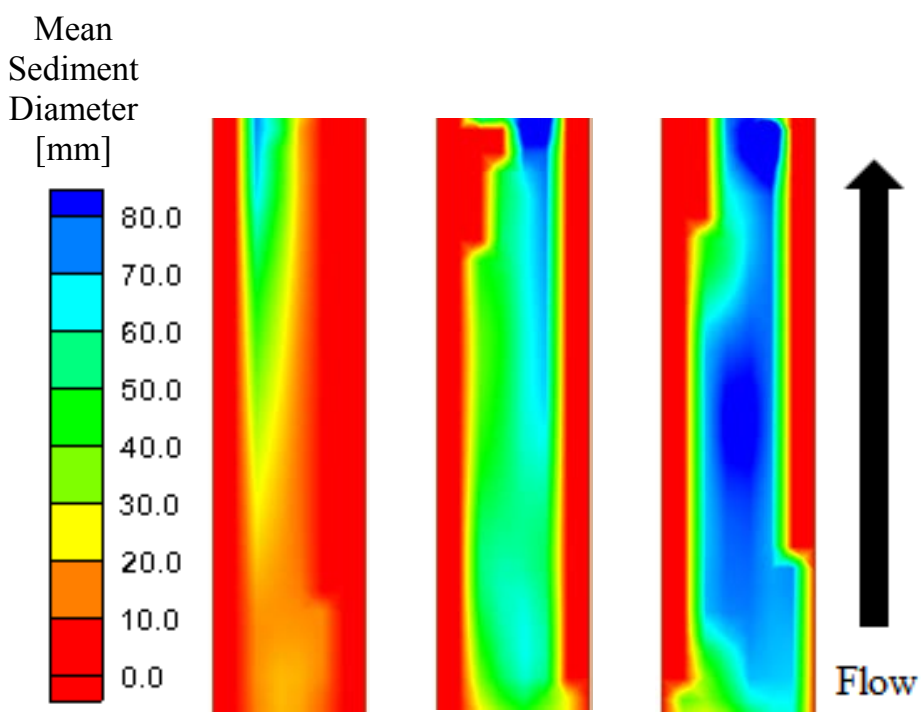

Figure 4-22: Mean Sediment Diameter in Millimeters for the 2-, 5-, and 25-year Flood from Simulations.

Table 4-6 summarizes the replenishment that was observed due to the 2014 flows and the simulations of hypothetical flows. The table shows that for observed replenishment following sediment removal, some locations are not applicable due to the very low flows observed through the spring flood season compared with the flow values obtained from regression equations that were used in the simulations.

Table 4-6: Review and Summary of Observed and Simulated Culvert Replenishment.

\begin{tabular}{lccc}
\hline & $\begin{array}{c}\text { Observed } \\
\text { Replenishment in } \\
\text { Culvert Barrel Pre- } \\
\text { Removal }\end{array}$ & $\begin{array}{c}\text { Observed } \\
\text { Replenishment in } \\
\text { Culvert Barrel Post } \\
\text { Removal }\end{array}$ & $\begin{array}{c}\text { Simulated } \\
\text { Replenishment } \\
\text { in Culvert } \\
\text { Barrel }\end{array}$ \\
\hline Hall's Fork & $\mathrm{Y}$ & $\mathrm{N} / \mathrm{A}$ & $\mathrm{Y}$ \\
Red Creek & $\mathrm{Y}$ & $\mathrm{N} / \mathrm{A}$ & $\mathrm{Y}$ \\
Salt Creek & $\mathrm{Y}$ & $\mathrm{Y}$ & $\mathrm{Y}$ \\
South Fork & $\mathrm{Y}$ & $\mathrm{N} / \mathrm{A}$ & $\mathrm{Y}$ \\
Summit Creek & $\mathrm{Y}$ & $\mathrm{Y}$ & not simulated \\
\hline
\end{tabular}




\subsection{Lateral Fining}

The sediment in the Salina Creek culvert displayed lateral fining. This culvert was selected to see if SRH-2D could simulate the observed phenomenon. Within the barrel, a large deposit of fine substrate rested against the left wall of the North barrel. In the middle of the culvert barrel, slightly larger material was deposited. Along the right wall of the barrel, the largest material was deposited in the culvert. As flows approach the culvert, they are pushed to the outer edges due to the upstream deposition of sediments. Additionally, obstructions on the southern portion of the stream push the flow toward the north barrel of the culvert. The flow conditions at the entrance explain why the sorting process is uni-lateral rather than visible against both walls. A numerical model was set up to simulate what was happening in the Salina Creek culvert. The simulations were run for 2-, 5-, and 25-year flood flows with the Parker sediment transport equation. Sediment samples were taken in the field to classify the degree of lateral fining.

\subsubsection{Field Data}

Sediment gradations are given from samples taken in three locations in the North barrel of the Salina Creek culvert (Figure 4-23) approximately 25 feet downstream from the culvert entrance. It was expected that this location was indicative of fully developed flow conditions in the barrel. The sediment gradation data is given showing percent finer based on mass (Figure 4-24). 


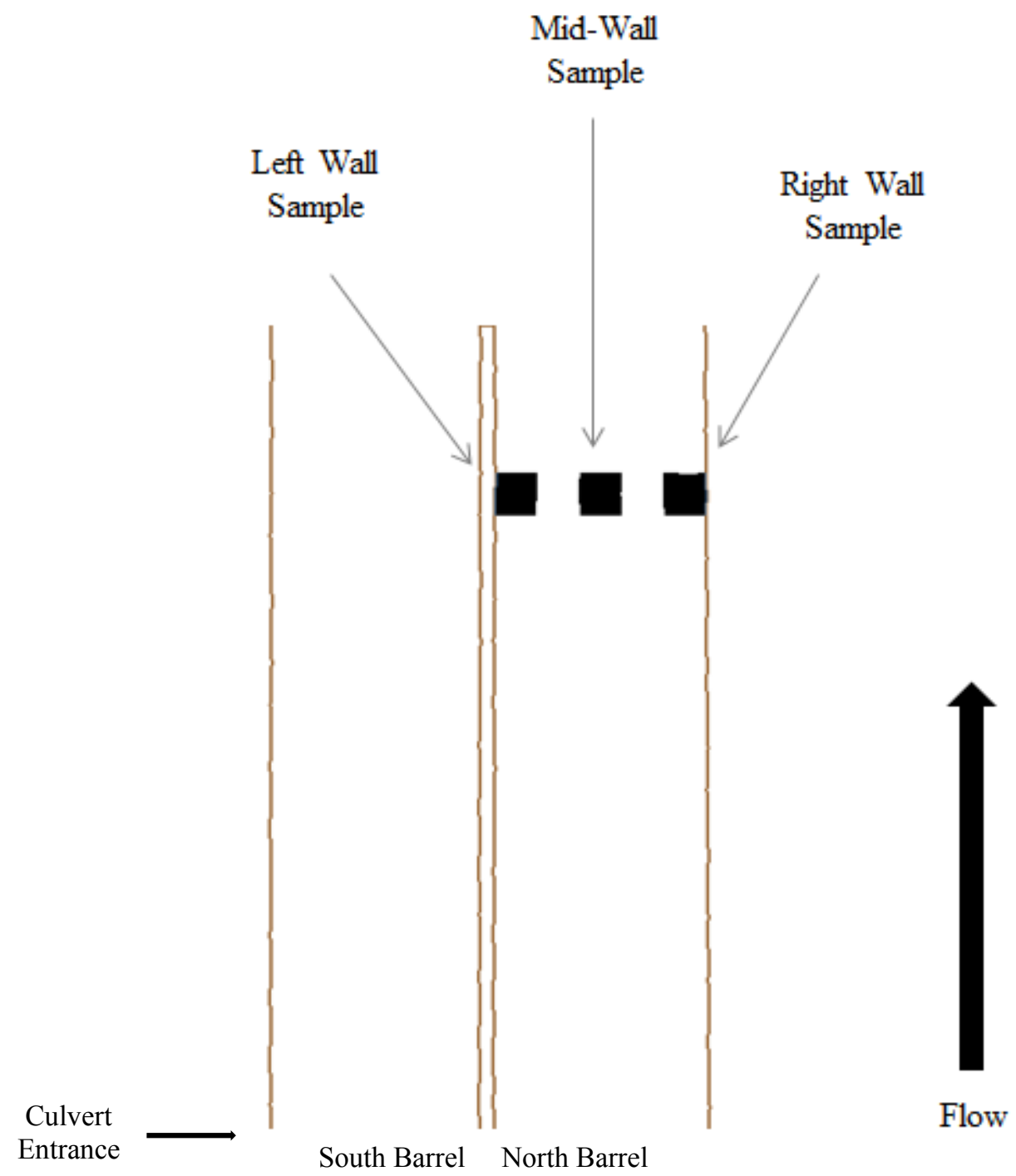

Figure 4-23: Plan View of Salina Creek Culvert: Sediment Sample Locations in North Barrel of Salina Creek Culvert. 


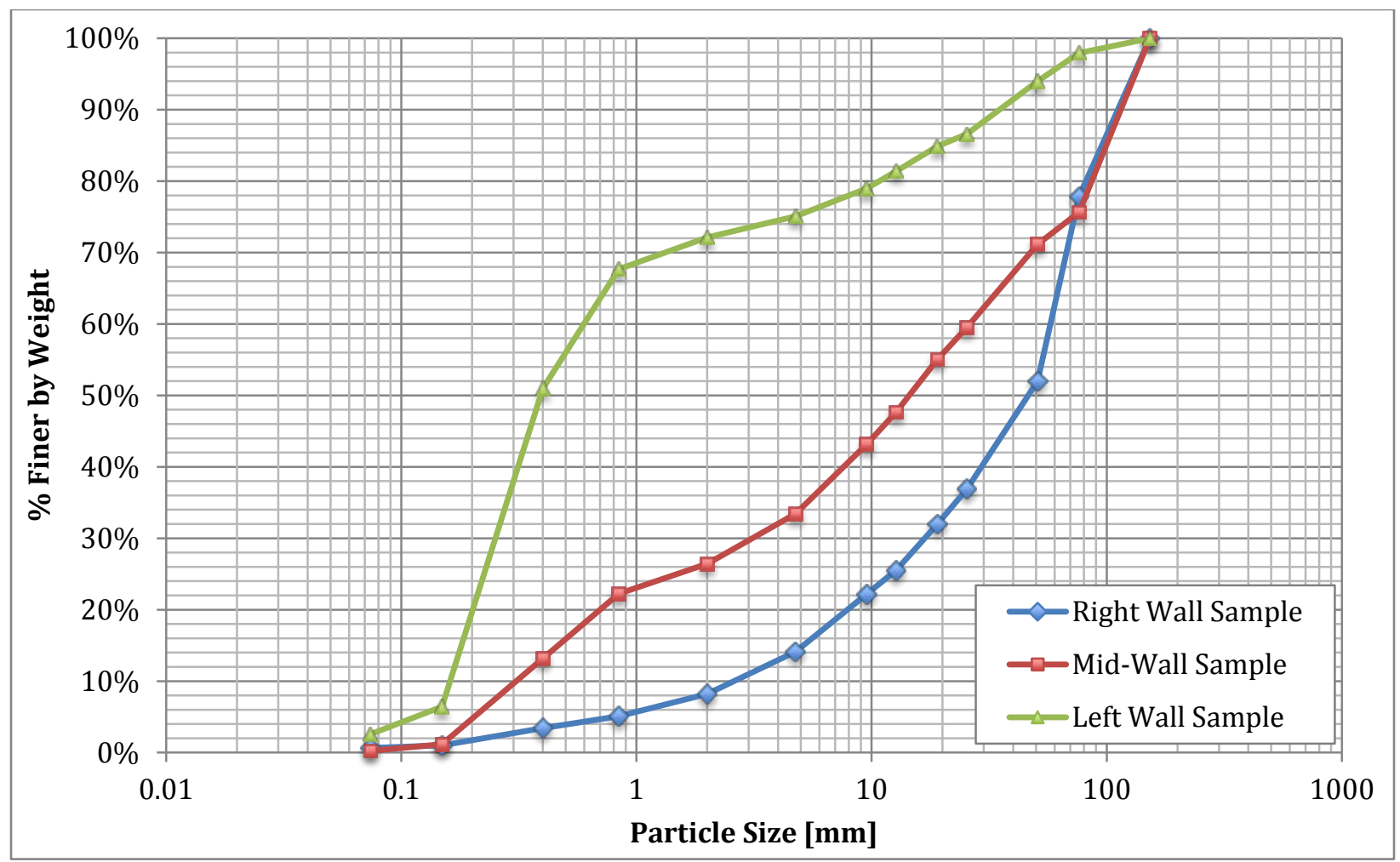

Figure 4-24: Sediment Gradation from Lateral Samples taken from Salina Creek.

\subsubsection{Numerical Model}

An SRH-2D simulation was created for Salina Creek. The results displayed below will show both the North (right) and South (left) culvert barrel (Figure 4-25, Figure 4-26, and Figure 4-27) with contour colors representing the mean sediment diameter through the barrel. While the figures show both barrels of the Salina Creek culvert, the physical samples discussed in the next section were taken from the North side only due to the flow conditions upstream of the culvert. 


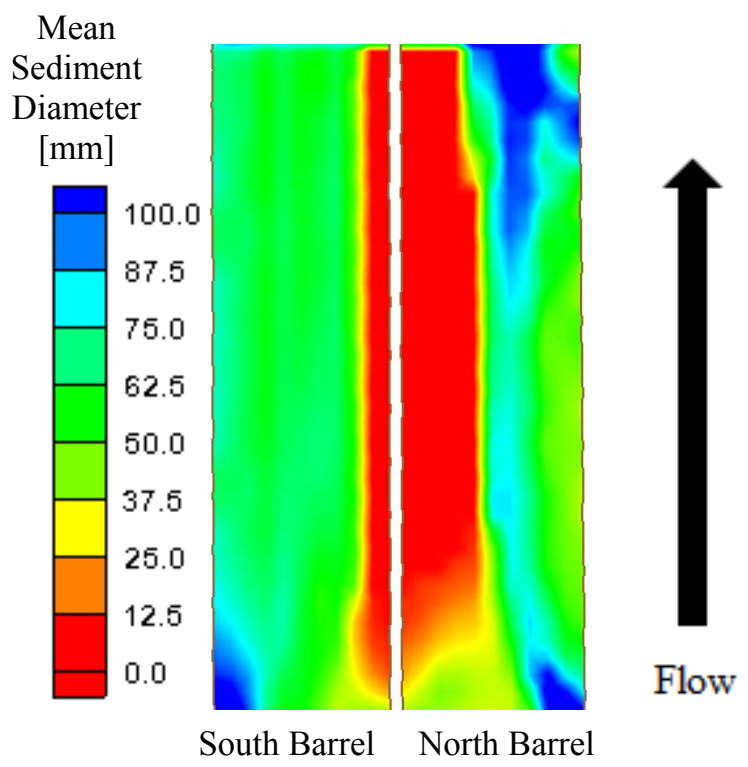

Figure 4-25: Plan View of Salina Creek Culvert: Mean Sediment Diameter in Millimeters for the 2-year Flood Obtained from the Simulation.

Mean

Sediment

Diameter

[mm]

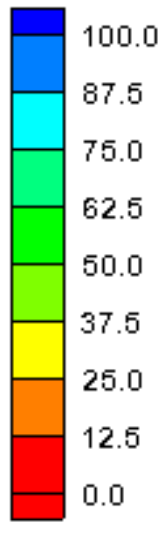
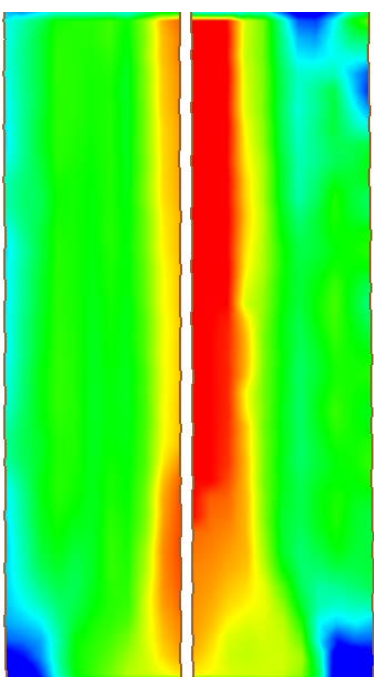

South Barrel North Barrel

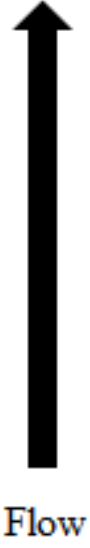

Flow

Figure 4-26: Plan View of Salina Creek Culvert: Mean Sediment Diameter in Millimeters for the 5-year Flood Obtained from the Simulation. 


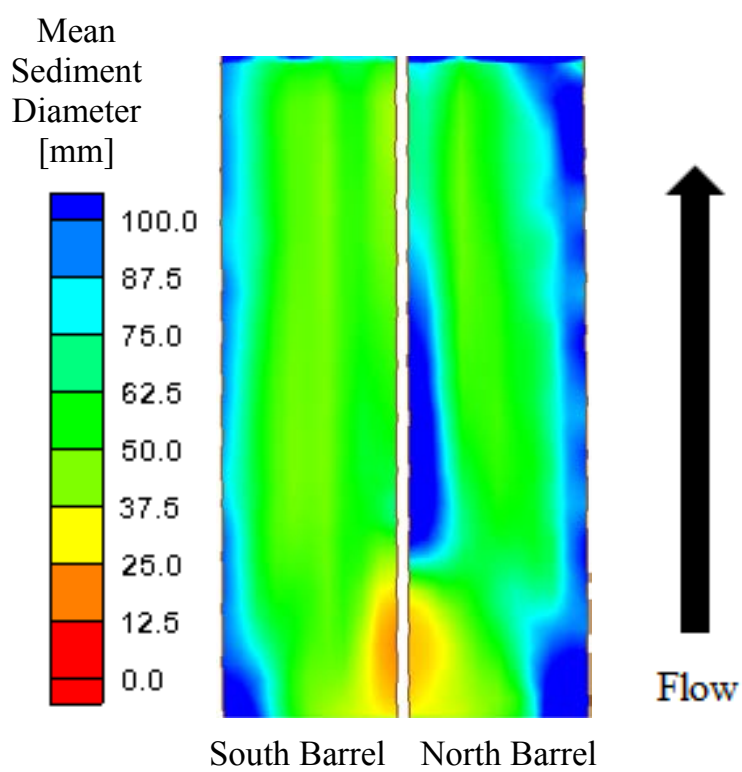

Figure 4-27: Plan View of Salina Creek Culvert: Mean Sediment Diameter in Millimeters for the 25-year Flood Obtained from the Simulations.

The numerical simulation showed greater diameters deposited on the right side of the North culvert barrel in all three cases to varying degrees. The smallest material is shown to deposit on the left wall of the North barrel.

A table of the mean sediment size from the field data as well as from the model simulations at the location of the sample is given in Table 4-7.

Table 4-7: Comparison of $\mathrm{D}_{50}$ Sediment Size for Field Data and Numerical Model Simulations.

\begin{tabular}{lccc}
\hline & $\begin{array}{c}\mathrm{D}_{50} \text { Left Wall } \\
\text { Sample [mm] }\end{array}$ & $\begin{array}{c}\mathrm{D}_{50} \text { Mid-Wall } \\
\text { Sample [mm] }\end{array}$ & $\begin{array}{c}\mathrm{D}_{50} \text { Right Wall } \\
\text { Sample [mm] }\end{array}$ \\
\hline Field Data & 0.4 & 14 & 46 \\
\hline 2-year Flood with Parker & $<1.0$ & 47 & 60 \\
5-year Flood with Parker & $<1.0$ & 51 & 55 \\
25-year Flood with Parker & 62 & 54 & 83 \\
\hline
\end{tabular}




\section{SUMMARY AND CONCLUSIONS}

\subsection{Upstream Deposition}

Field observations revealed the presence of upstream deposition of gravels and cobbles near the selected culvert entrances. Sediments are able to deposit when the headwater-to-culvert rise ratio climbs to a point such that the water velocity decreases near the culvert entrance and larger sediments fall out of the water column. For small flows and for very large culverts, the headwater-to-culvert rise ratio will remain small; therefore, the ponding or backwater portion of the reach that occurs when the flow is backed up above the culvert contraction will not occur and sediments will not deposit. Overall, the flows observed in 2014 were low; therefore, the deposition did not occur in most locations even though evidence of the upstream deposition was observed at Salt Creek and Salina Creek from earlier events.

The use of SRH-2D to simulate upstream deposition of sediments was successful.

However, very little data was available to calibrate the model runs. Sediment transport computations require detailed data and are subject to divergence; therefore, calibration of a sediment transport model will allow for greater detail of analysis of upstream deposition. SRH-

2D may be an important tool for engineers to use in culvert design to determine the magnitude of upstream deposition in extreme flood events. The ability to model deposition of sediments above 
a culvert will assist engineers as they determine scour potential downstream and culvert plugging concerns.

\subsection{Culvert Replenishment}

Culvert replenishment was observed in the field at all locations due to flows from flood events pre-dating the 2014 water year, and replenishment was observed at Salt Creek and Summit Creek for the current water year. Replenishment at each location was simulated with a numerical model. The results from the field observations and numerical simulations show the critical relationship that exists between flood flows and the ability of the culvert to replenish. Sediment replenishment requires a discharge great enough to move the bed. Culvert replenishment is common when the geological conditions allow for an active bed. Threshold conditions limit the ability of a stream to replenish a culvert during high flows. Culvert replenishment must be considered in culvert design, especially when designing embedded culverts. It is recommended that SRH-2D be used in conjunction with a geomorphological study when culverts are designed for embedment. The results from this study show that culvert replenishment is very active at stream crossing locations. Replenishment cannot be ignored or overlooked as HEC 26 suggests. SRH-2D is able to predict replenishment and should be used as part of the design process. The use of SRH-2D will also act as a reference for prevention of problems associated with replenishment such as clogging.

Since each culvert considered in this study was selected based on the natural deposition that had already occurred, further work should be completed to verify whether SRH-2D will show no deposition in culverts where deposition does not occur. Further studies should also research the maximum flow or minimum return period that will allow for replenishment 
considering that there is such a threshold. Considering culvert replenishment in design will decrease costs of culverts that otherwise would be oversized, require additional substrate to be added to the barrel, or require constant maintenance. Sustainable culvert design requires that replenishment be considered and modeled.

\subsection{Lateral Fining}

SRH-2D proved successful in simulating lateral fining that was observed in the field when simulated with smaller flood regimes. The results simulated for the 25 -year flood did not show the lateral diversity of sediment sizes to the extent of the other simulation runs. While there is not field data for the 25 -year flood against which to compare the simulated results, the results show that there is a flow at which the confining geometry of the culvert does not create significant secondary currents or low velocity zones against the side-walls to cause substantial lateral fining. SRH-2D can be used to model and study lateral fining in relatively small hydraulic structures. Lateral fining produces a spatially diverse distribution of sediment sizes allowing swimming fish to select swim paths based not only on velocity and turbulence, but on sediment size as well. Where culverts are designed with artificial substrate in the barrel, lateral sediment sizes should be considered to account for the diversity of fish that will travel through the culvert. Therefore, simulating lateral fining during culvert design will allow engineers to size a single culvert installation for multiple fish species with a wide range of swim speeds and endurance.

\subsection{Final Outcomes}

The final results from the study are summarized in Table 5-1. Each element considered in the study plays a significant role to the sustainability and life span of stream crossings. Each 
element considered in the study should be considered in culvert design. The tools outlined in this work will aid designers in meeting the hydraulic, sediment, and aquatic organism needs.

Table 5-1: Summary of Results.

\begin{tabular}{lcccccc}
\hline & \multicolumn{2}{c}{$\begin{array}{c}\text { Deposition at Culvert } \\
\text { Entrance }\end{array}$} & \multicolumn{2}{c}{ Culvert Replenishment } & \multicolumn{2}{c}{ Lateral Fining } \\
& Field & SRH-2D & Field & SRH-2D & Field & SRH-2D \\
& & Y & N & Y & N/A & N/A \\
\hline Hall's Fork & N/A & N & N/A & Y & N/A & N/A \\
Red Creek & Y & N/A & N/A & N/A & Y & Y \\
Salina Creek & Y & Y & Y & Y & N/A & N/A \\
Salt Creek & N/A & Y & N/A & Y & N/A & N/A \\
South Fork & N/A & not simulated & Y & not simulated & N/A & N/A \\
Summit Creek & & & & & & \\
\hline
\end{tabular}




\section{REFERENCES}

"O.D.O.T. Hydraulics Manual." Oregon Department of Transportation, 2014.

ASTM. "Standard Test Methosd for Particle-Size Distribution (Gradation) of Soils Using Sieve Analysis." In ASTM D6913 - 04(2009), ASTM D6913 - 04(2009). West Conshohocken, PA: www.astm.org, 2009.

Brush, Lucien M. "Sediment Sorting in Alluvial Channels." In Primary Sedimentary Structures and Their Hydrodynamic Interpretation, edited by Gerard V. Middleton, 12, 25-33. Tulsa, Oklahoma: Society of Economic Paleontologists and Mineralogists, 1965.

Bunte, Kristin and Steven R. Abt. Sampling Surface and Subsurface Particle-Size Distribution in Wadable Gravel-and Cobble-Bed Streams for Analyses in Sediment Transprot, Hydraulics, and Strembed Monitoring. Fort Collins, Colorado: Rocky Mountain Research Station, 2001, RMRS-GTR-74.

Cafferata, Peter, Thomas Spittler, Michael Wopat, Greg Bundros and Sam Flanagan. Designing Watercourse Crossings for Passage of 100-Year Flood Flows, Wood, and Sediment, 2004. California Forestry Report No. 1.

Dey, Subhasish and Rajkumar V. Raikar. "Scour in Long Contractions." Journal of Hydraulic Engineering 131, no. 12 (2005): 1036-1049.

Ead, S., N. Rajaratnam, C. Katopodis and F. Ade. "Turbulent Open-Channel Flow in Circular Corrugated Culverts." Journal of Hydraulic Engineering 126, no. 10 (2000): 750-757.

Gill, Mohammad Akram. "Bed Erosion in Rectangular Long Contraction." Journal of the Hydraulics Division 107, (1981): 273-284.

Hahn, E. and D. Lyn. "Anomalous Contraction Scour? Vertical-Contraction Case." Journal of Hydraulic Engineering 136, no. 2 (2010): 137-141.

Haight, W.H. "Culvert." Google Patents, 1912.

Kenney, Terry A., Chris D. Wilkowske and Shane J. Wright. Methods for Estimating Magnitude and Frequency of Peak Flows for Natural Streams in Utah. Reston, Virginia, 2008, SIR 2007-5158.

Kerenyi, Kornel and Jorge Pagán-Ortiz. Testing Bottomless Culverts. Federal Highway Administration, 2007, FHWA-HRT-07-004. 
Kilgore, Roger T., Bart S. Bergendahl and Rollin H. Hotchkiss. Hydraulic Engineering Circular Number 26: Culvert Design for Aquatic Organism Passage. 2010, FHWA-HIF-11-008 HEC-26.

Lai, Yong G. and Blair P. Greimann. "Predicting Contraction Scour with a Two-Dimensional Depth-Averaged Model." Journal of Hydraulic Research 48, no. 3 (2010): 383-387.

Lim, Siow-Yong and Nian-Sheng Cheng. "Scouring in Long Contractions." Journal of Irrigation \& Drainage Engineering 124, no. 5 (1998): 258.

Parker, Gary, Sundararajan Dhamotharan and Heinz Stefan. "Model Experiments on Mobile, Paved Gravel Bed Streams." Water Resources Research 18, no. 5 (1982): 1395-1408.

Powell, D. Mark. "Patterns and Processes of Sediment Sorting in Gravel-Bed Rivers." Progress in Physical Geography 22, no. 1 (1998): 1-32.

Richmond, Marshall C., Zhiqun Deng, Gregory R. Guensch, Hans Tritico and Walter H. Pearson. "Mean Flow and Turbulence Characteristics of a Full-Scale Spiral Corrugated Culvert with Implications for Fish Passage." Ecological Engineering 30, no. 4 (2007): 333-340.

Tsihrintzis, V. "Effects of Sediment on Drainage-Culvert Serviceability." Journal of Performance of Constructed Facilities 9, no. 3 (1995): 172-183.

Turnipseed, D. Phil and Vernon B. Sauer. "Discharge Measurements at Gaging Stations." In Techniques and Methods 3-A8, 3. Reston, Virginia: USGS, 2010.

Turnipseed, D. Phil and Vernon B. Sauer. "Stage Measurement at Gaging Stations." In Techniques and Methods 3-A7, 3. Reston, Virginia: USGS, 2010.

USFS. Stream Simulation: An Ecological Approcach to Providing Passage for Aquatic Organisms at Road-Stream Crossings. San Dimas, CA: USDA, 2008, 0877 1801SDTDC.

Wargo, Rebecca S. and Richard N. Weisman. "A Comparison of Single-Cell and Multicell Culverts for Stream Crossings1." Journal of the American Water Resources Association 42, no. 4 (2006): 989-995.

Wellman, Jennifer C., Daniel L. Combs and S. Bradford Cook. "Long-Term Impacts of Bridge and Culvert Construction or Replacement on Fish Communities and Sediment Characteristics of Streams." Journal of Freshwater Ecology 15, no. 3 (2000): 317-328.

Yen, C. and K. Lee. "Bed Topography and Sediment Sorting in Channel Bend with Unsteady Flow." Journal of Hydraulic Engineering 121, no. 8 (1995): 591-599. 


\section{APPENDIX A - FIELD DATA}

\section{A.1 Sediment Gradations - Pebble Counts}

The pebble count data was obtained as outlined on page 31 . Pebble counts were taken in five of the six streams. The Summit Creek sediment gradation data will be gathered for subsequent studies.

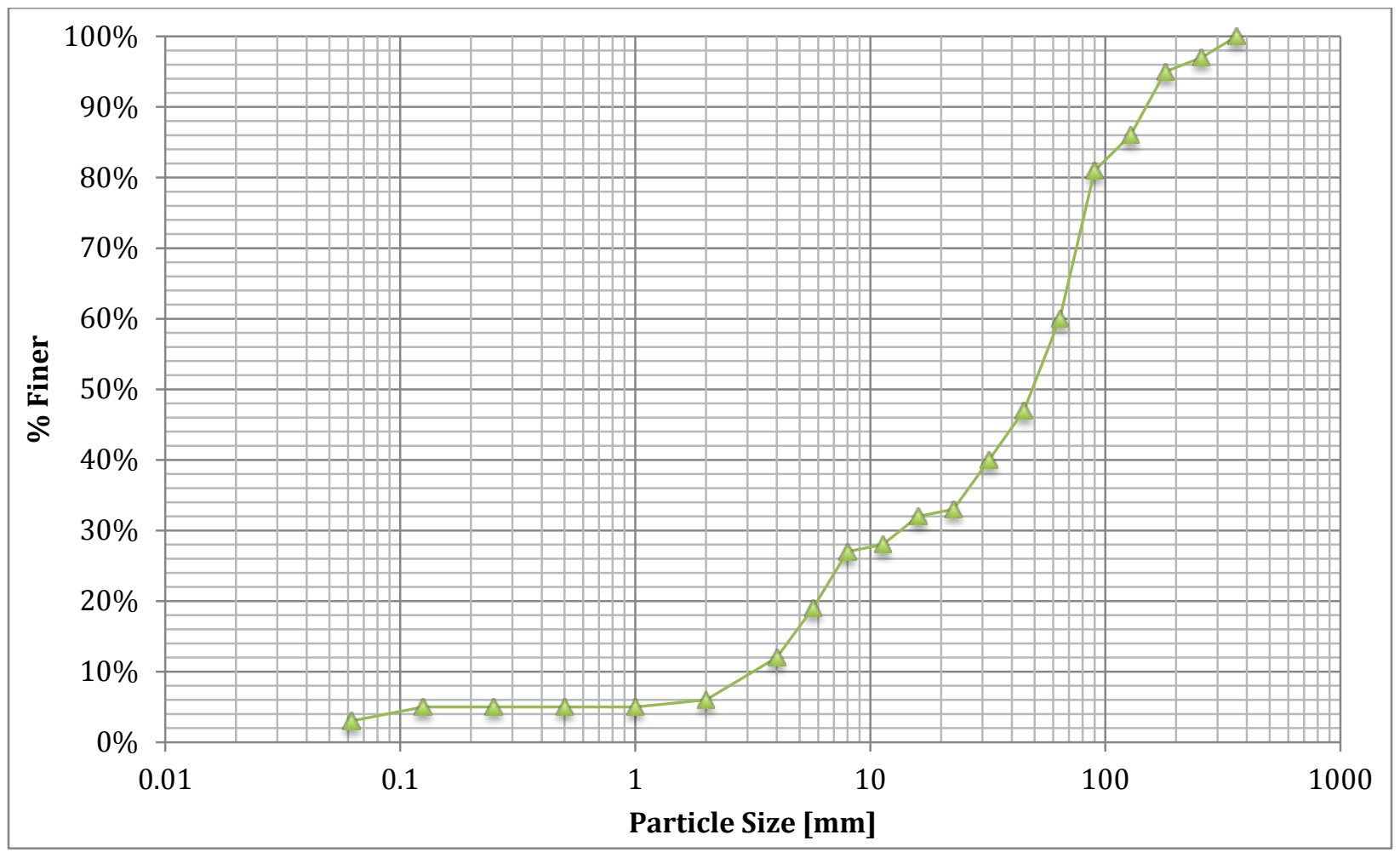

Figure A-1: Sediment Gradation for Hall's Fork. 


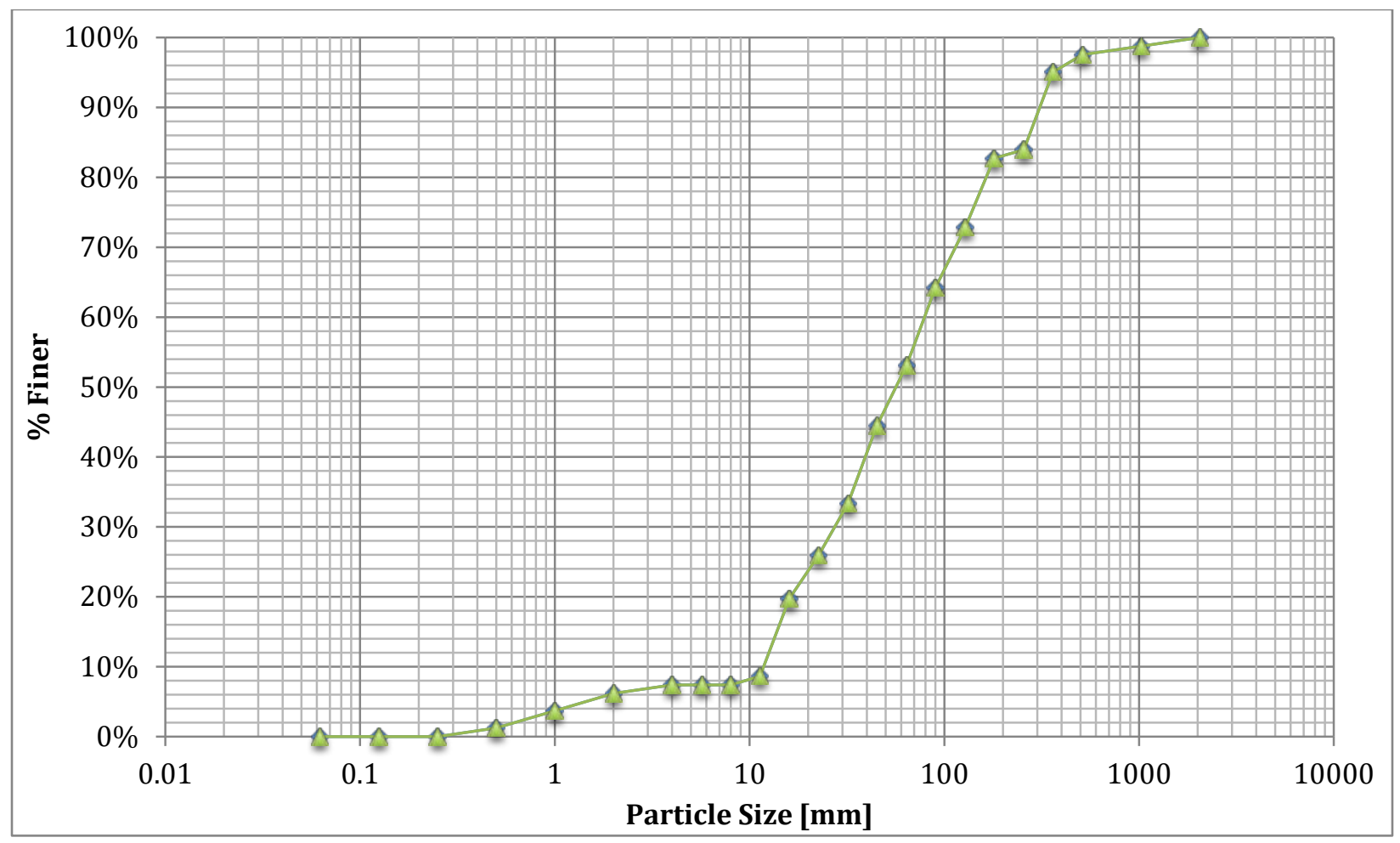

Figure A-2: Sediment Gradation for Red Creek.

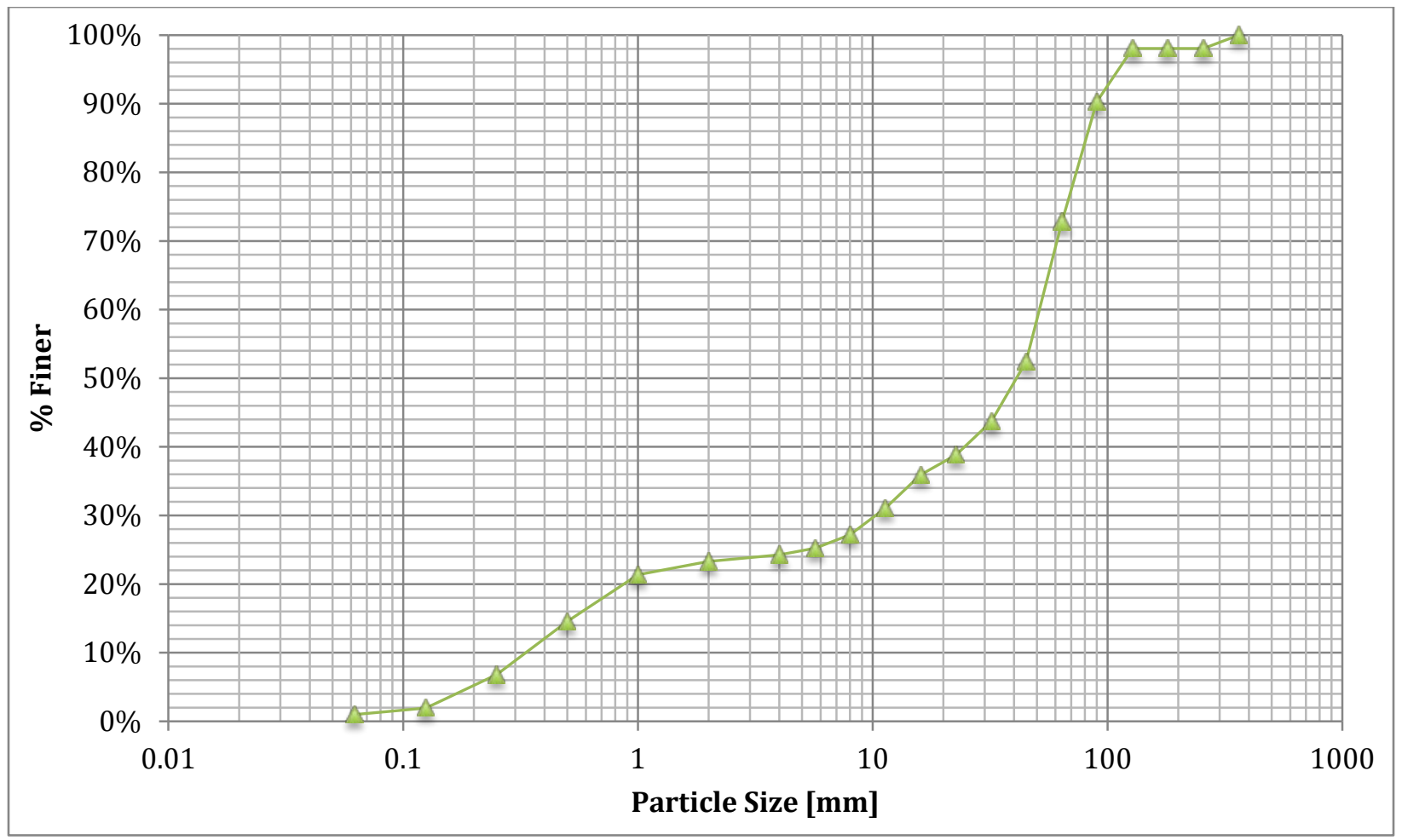

Figure A-3: Sediment Gradation for Salina Creek. 


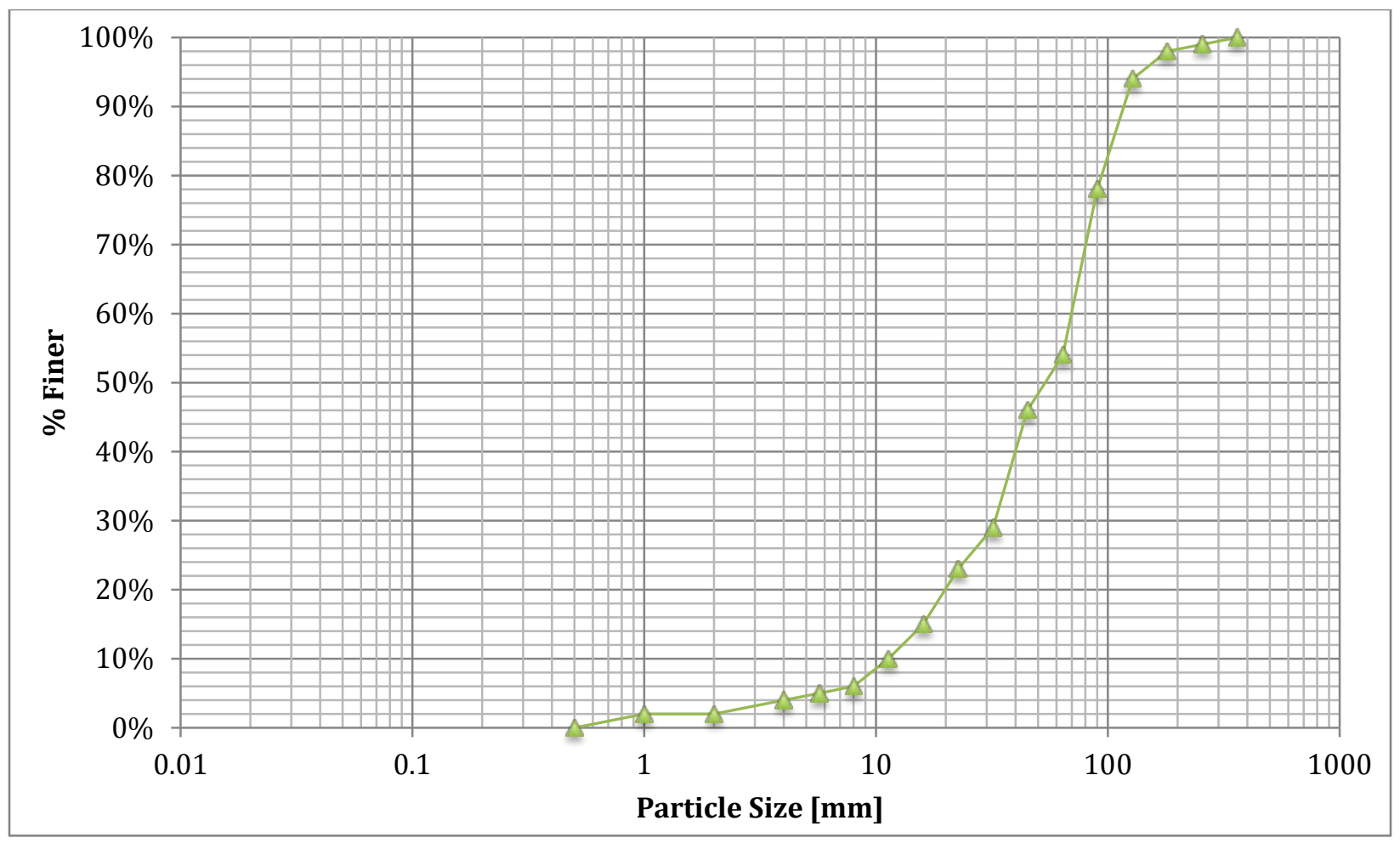

Figure A-4: Sediment Gradation for Salt Creek.

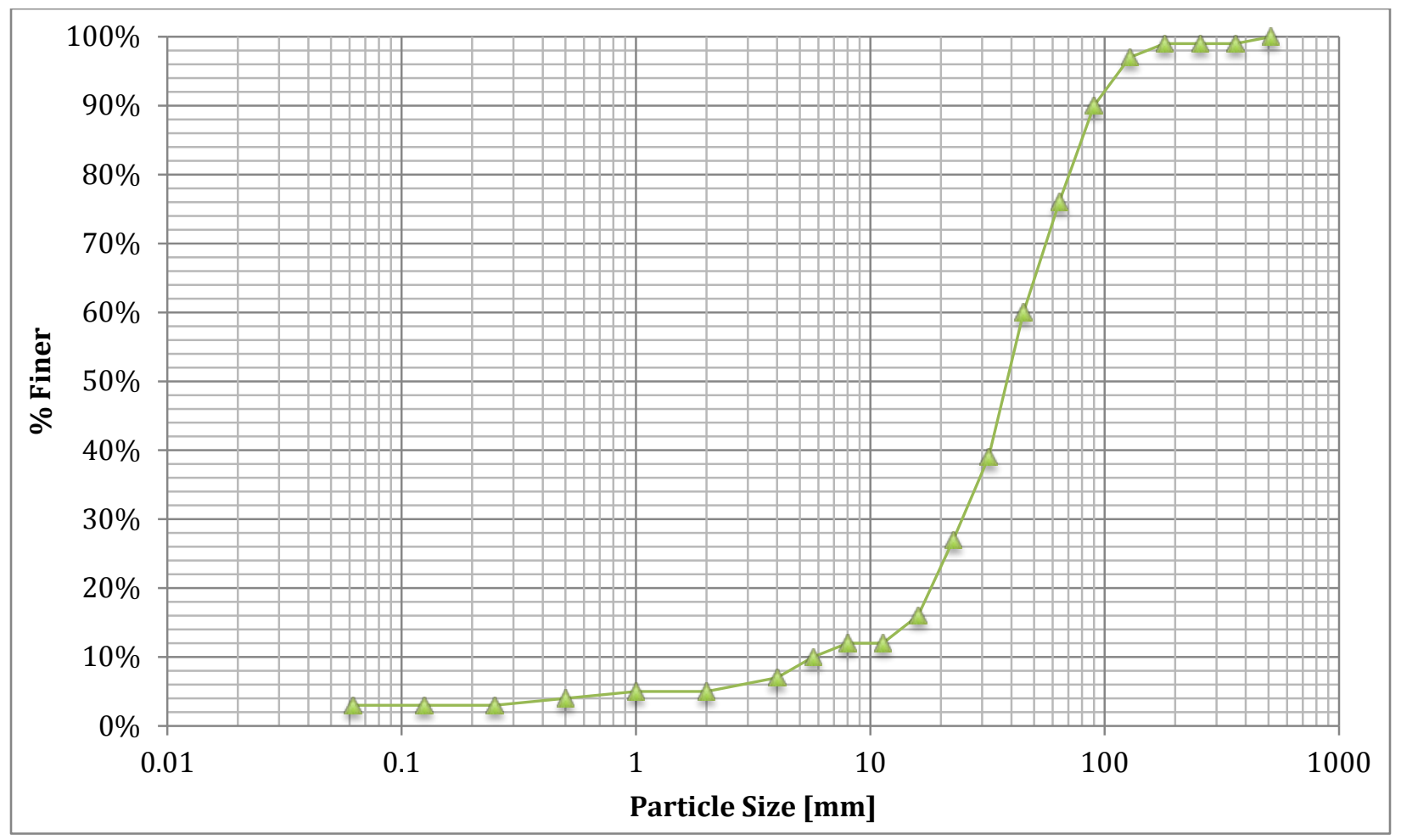

Figure A-5: Sediment Gradation for South Fork. 


\section{A.2 Crest Stage Gage Design}

The Crest Stage Gage installations followed the design given by the USGS and outlined below.

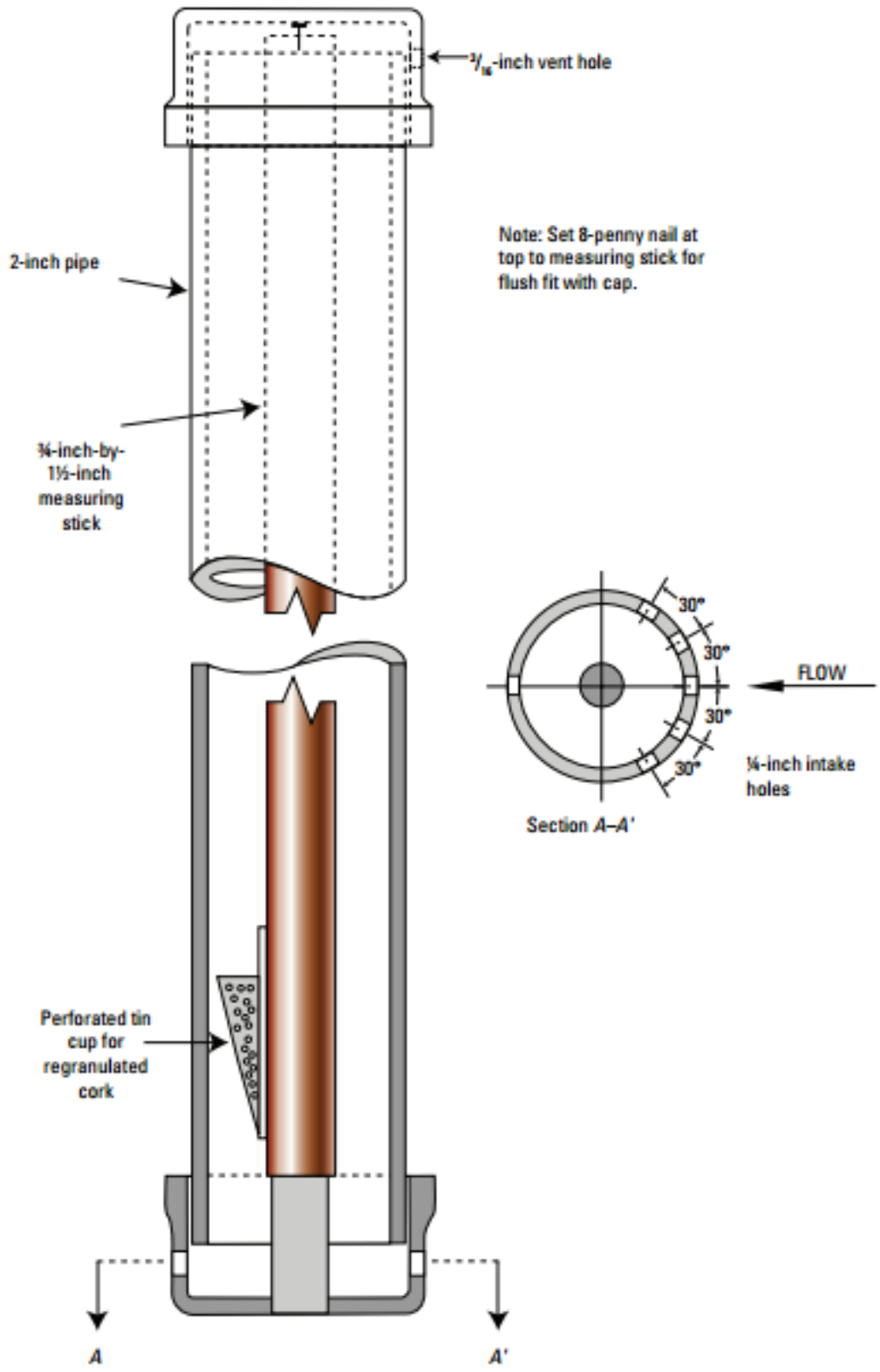

Figure A-6: Crest-Stage Gage Design (USGS 2010). 


\section{A.3 Rating Curves}

A stage discharge rating curve was created for Hall's Fork, Salt Creek, South Fork, and Summit Creek. Red Creek was omitted from the curve development due to the low flow conditions observed this year. Rating curves are given in

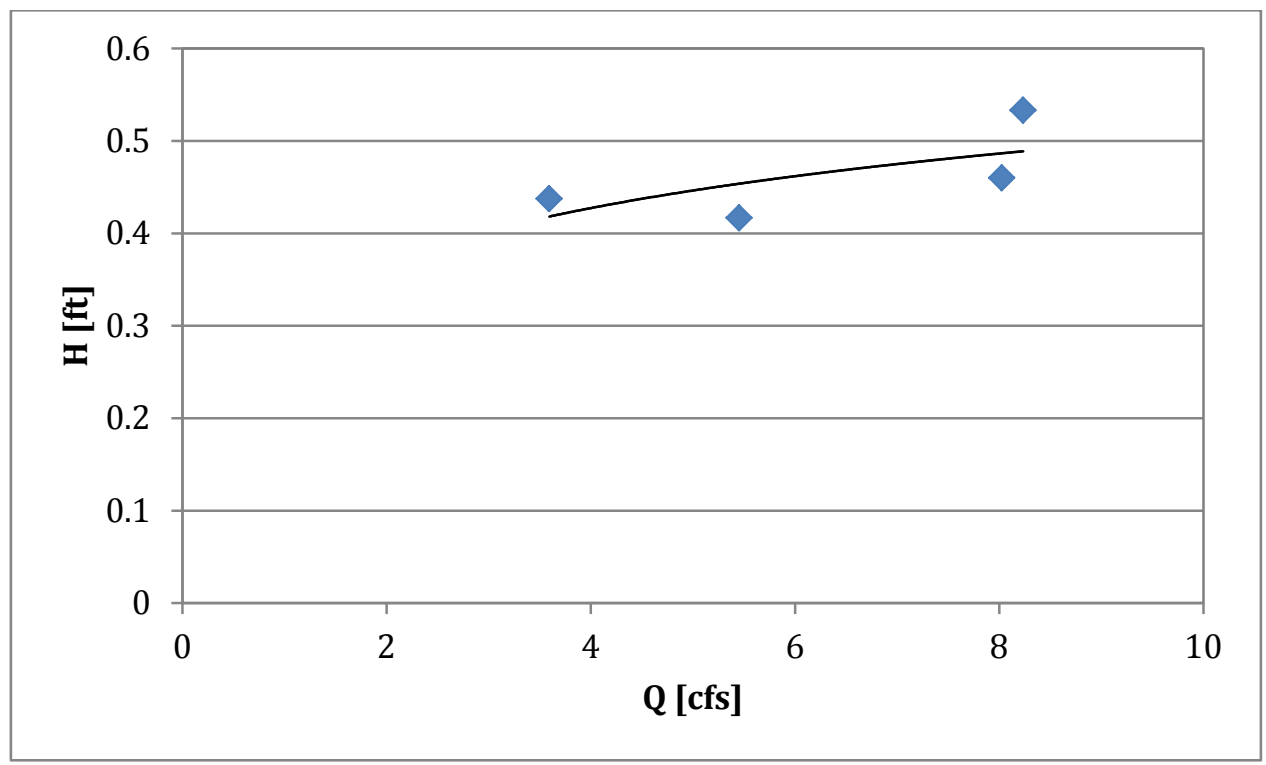

Figure A-7: Hall's Fork Rating Curve, Figure A-8, Figure A-9, and Figure A-10.

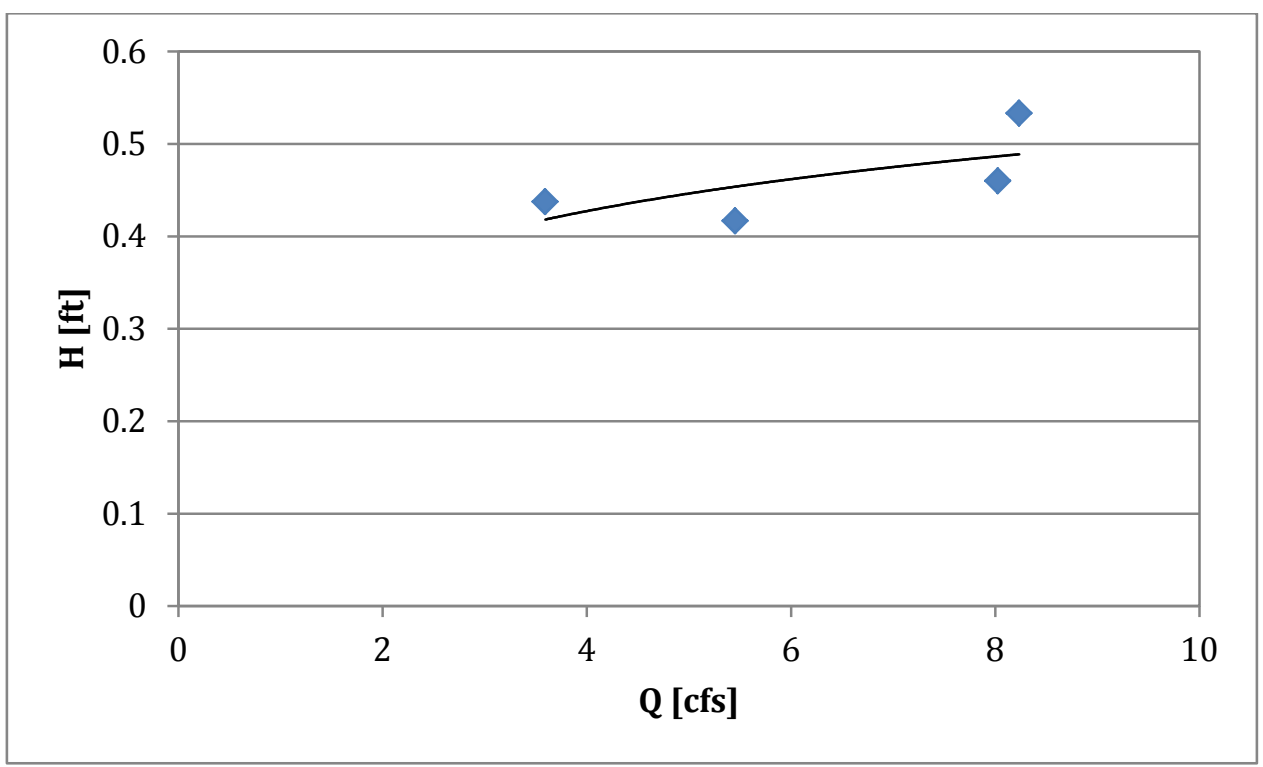

Figure A-7: Hall's Fork Rating Curve. 


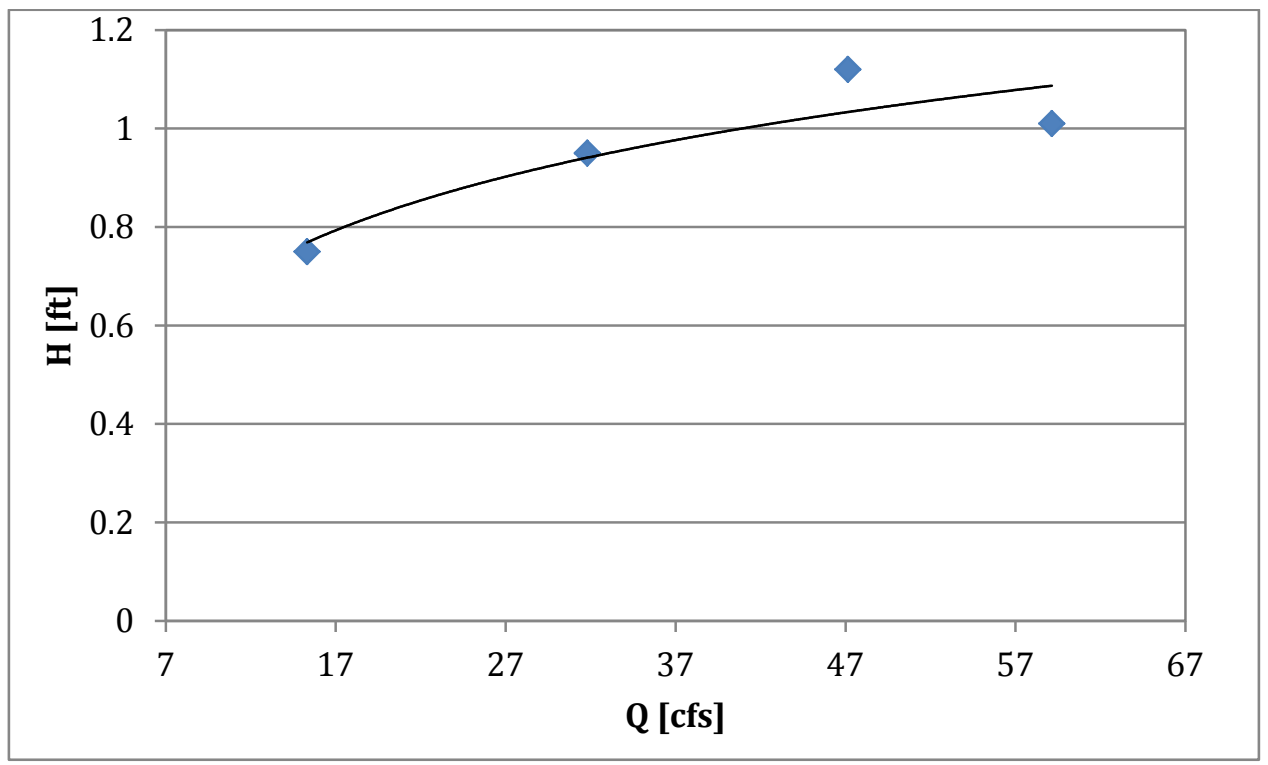

Figure A-8: Salt Creek Rating Curve.

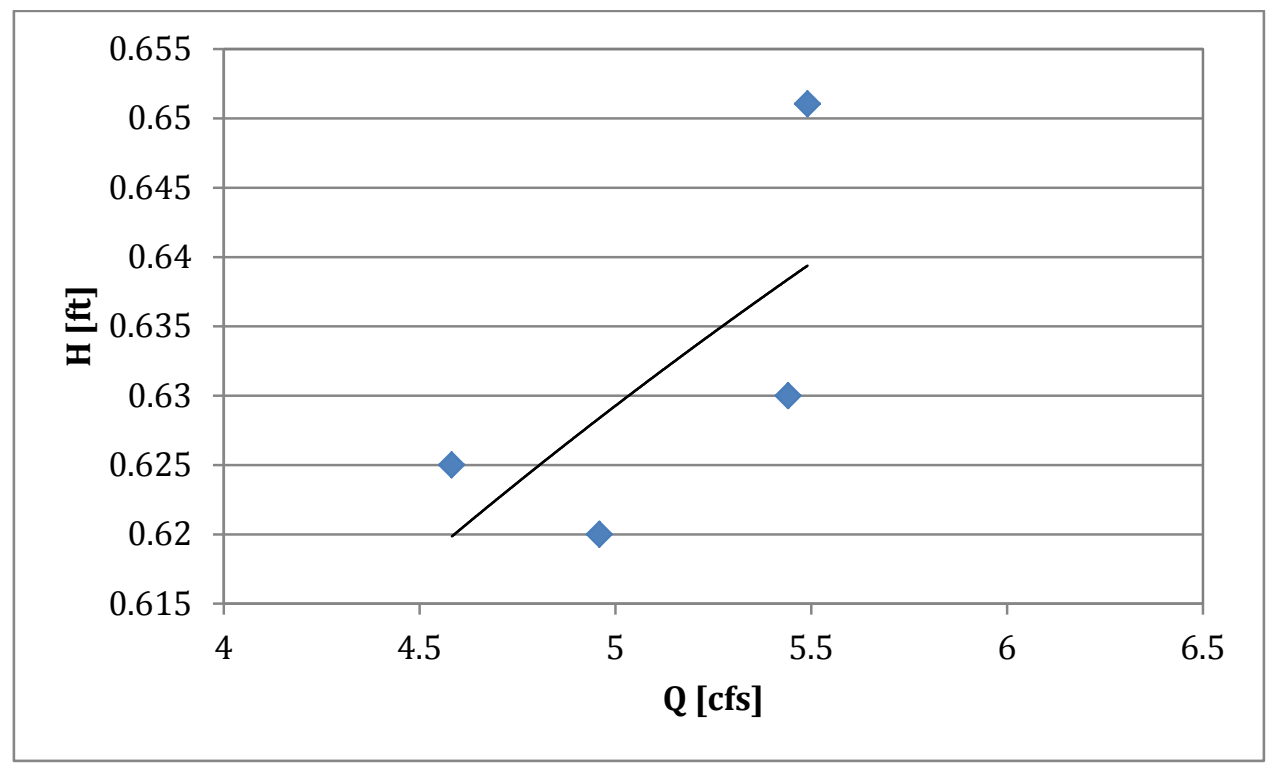

Figure A-9: South Fork Rating Curve. 


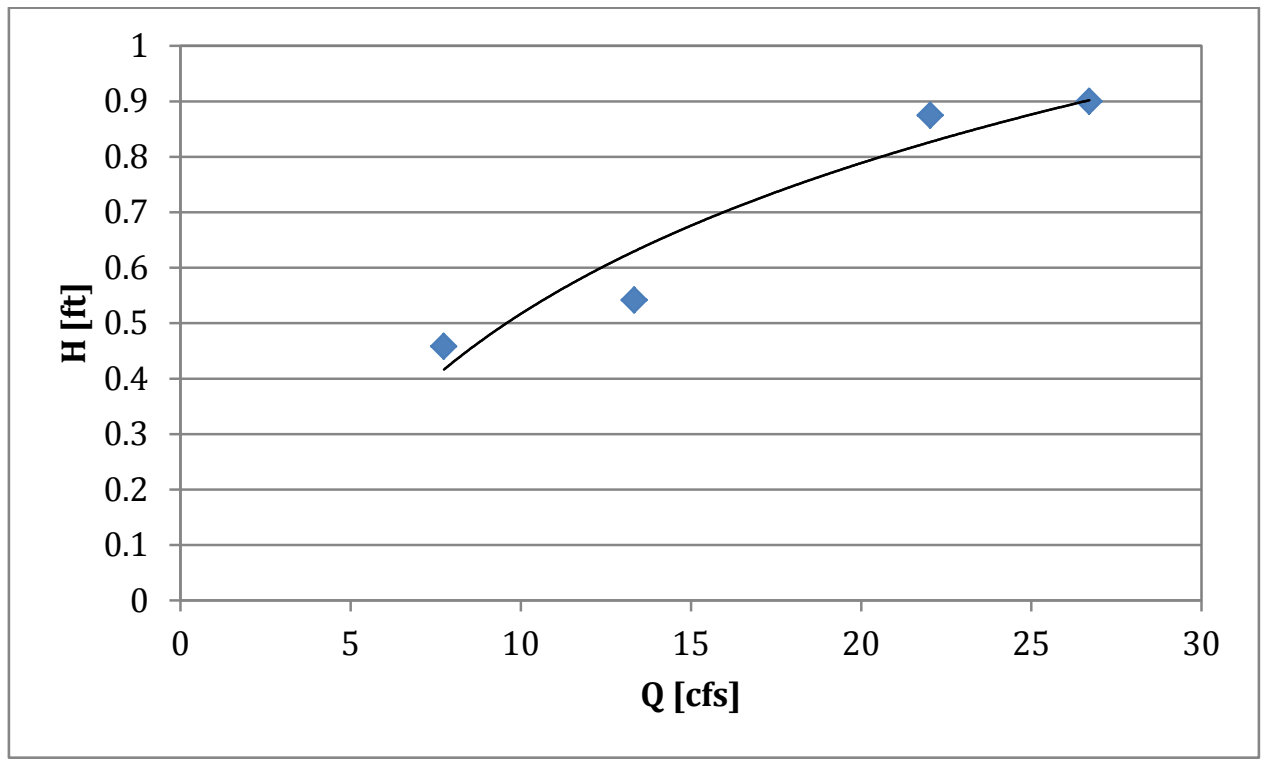

Figure A-10: Summit Creek Rating Curve. 